$$
\begin{gathered}
\text { UNIVERSIDADE DE BRASÍLIA - UnB } \\
\text { INSTITUTO DE CIÊNCIAS HUMANAS - IH } \\
\text { DEPARTAMENTO DE SERVIÇO SOCIAL - SER }
\end{gathered}
$$

\title{
POR QUE SERVIÇO SOCIAL? \\ UMA ANÁLISE DE ALGUMAS CONCEPÇÕES QUE \\ INFLUENCIAM A ESCOLHA DA PROFISSÃO NA CONTEMPORANEIDADE.
}

Estudo apresentado como requisito para a obtenção de menção na disciplina Trabalho de Conclusão de Curso, sob a orientação da professora Patrícia Cristina Pinheiro de Almeida.

Marcos Fernandes Aquino - 01/26420

Brasília, 1\%/2007. 


\section{AGRADECIMENTOS}

Agradeço, primeiramente, à Santíssima Trindade (Pai, Filho e Espírito Santo) e à intercessão terna de Maria Santíssima, mãe de Deus e nossa. Aos meus pais, ao meu irmão-amigo, aos avós, familiares e amigos-irmãos: sem os testemunhos, os valores, a compreensão e paciência, as orações, os incentivos e as palavras animadoras que recebo de vocês em todos os momentos certamente minha existência não seria tão feliz.

A todos os professores, funcionários e colegas do Departamento de Serviço Social da Universidade de Brasília. Com vocês muito aprendi e partilhei, procurei e encontrei, caminhei e descansei, sorri e chorei. Todo o meu apoio e força nesta perene luta pela construção de uma sociedade justa e igualitária, onde todos tenham vida em plenitude.

Gratidão especial à minha orientadora, professora Patrícia Pinheiro. Muito obrigado pela paciência, alegria, disponibilidade, respeito à autonomia, objetividade e segurança ao longo de todo este processo. Manifesto também minha gratidão ao professor Pedro Demo (orientador de PIBIC), com quem pude aprender a aprender. Os meus agradecimentos à professora Rosa Helena Stein, pela gentileza e colaboração para a execução deste estudo, bem como aos membros da banca examinadora, que se propuseram a contribuir com seus valiosos conhecimentos e argutas observações neste singelo trabalho. Gratidão aos estudantes (calouros) do $2 \% / 2006$, pela acolhida e rica contribuição a este projeto.

Enfim, como diria Fernando Sabino: "De tudo ficaram três coisas: a certeza de que estamos sempre começando... a certeza de que é preciso continuar... a certeza de que seremos interrompidos antes de terminar...". Paz e bem a todos!

\section{INFORMAÇÕES GERAIS}

- Data da defesa: 07/05/2007

- Banca Examinadora:

Prof. Dra Rosa Helena Stein (SER/UnB)

Prof. Dra Maria Lúcia Pinto Leal (SER/UNB) 


\section{SUMÁRIO}

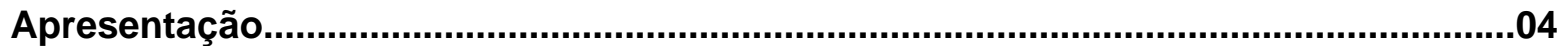

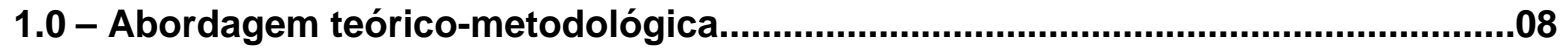

1.1 - Fundamentação teórica: categorias gerais de análise...................................08

1.2 - Metodologia de trabalho.....................................................................................21

2.0 - A questão social e as origens do Serviço Social..............................................25

2.1 - Questão social, capitalismo monopolista e Serviço Social..............................25

2.2 - Neotomismo e positivismo na profissão.......................................................33

2.3 - Algumas protoformas do Serviço Social no Brasil........................................42

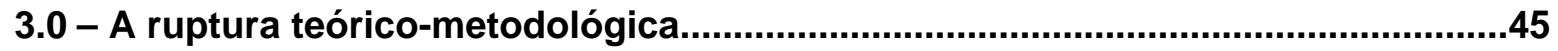

3.1 - O movimento de Reconceituação...................................................................46

3.2 - As novas influências: fenomenologia e marxismo........................................49

4.0 - O Serviço Social na contemporaneidade........................................................54

4.1 - Neoliberalismo, $3^{\circ}$ setor e a refilantropização da questão social.....................55

4.2 - O projeto ético-político profissional...........................................................61

4.3 - Perfil dos assistentes sociais contemporâneos............................................62

5.0 - Por que Serviço Social? ...............................................................................65

5.1 - Motivações e concepções: indagando calouros do 2\%/2006.............................65

5.2 - Perfil socioeconômico.............................................................................66

5.3 - Apresentação e análise crítica dos dados qualitativos.................................67

6.0 - Considerações finais........................................................................................72

Referências bibliográficas...............................................................................

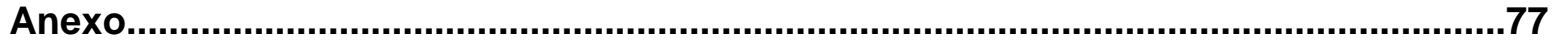




\section{Apresentação}

Por que Serviço Social?

O Trabalho de Conclusão de Curso (TCC) que segue nas próximas páginas pretende discutir o tema das motivações e concepções que levam, de maneira cada vez mais crescente, a tantas pessoas optarem pelo curso de Serviço Social. Embora de enunciado aparentemente simples - muitos diriam até singelo demais -, tal questão reveste-se, quando olhada mais detidamente, de enorme relevância e complexidade, porquanto implica necessariamente revisitar e (re) pensar a própria gênese, natureza, sentido, identidade, objeto, finalidades e imagens que o Serviço Social foi (vai) alocando e construindo nos diferentes espaços e tempos, a partir de seu nascimento em berço capitalista de cariz monopolista, bem como a repercussão que os valores, simbologias, projeto ético-político, aspectos socioculturais e concepções pessoais e/ou coletivas que envolvem tais questões influenciam ou potencializam no momento da escolha. Todavia, levantar esta indagação não significa investir em meras abstrações ideológicas, saudosismos ou ainda pretensões exageradas da profissão, transformando-a em algo semelhante a uma vocação religiosa ou mesmo a uma missão heróica. Por outro lado, também não são elogios ao acaso, às demandas do mercado ou ao pragmatismo empírico como caminhos que necessariamente levam à escolha do curso. Trata-se, sobretudo, de um movimento dialético e multifacetado que busca apreender em todas estas manifestações e recorrências possíveis elucidações e sentidos para uma melhor compreensão da dinâmica de nossa profissão e dos sujeitos que a compõem. Numa palavra: é um questionamento do tipo "conhece-te a ti mesmo" que se coloca ao Serviço Social. Parafraseando São Jerônimo, poder-se-ia dizer que "ninguém ama o que não conhece", significando em nosso caso específico que é mister conhecer melhor o Serviço Social para bem entender, inclusive, os fundamentos das imagens e até mesmo dos estereótipos que a sociedade estabelece acerca desta profissão e de seus profissionais.

Duas perguntas principais constituíram-se simultaneamente como eixo-norteador $\mathrm{e}$ objetos de análise deste estudo. A primeira foi: por que, entre tantas outras profissões, escolher o Serviço Social? Procurei com esta indagação apreender junto aos estudantes do curso de Serviço Social da Universidade de Brasília (os sujeitos da pesquisa), as distintas motivações, sentidos e valores que os encaminharam para escolherem o curso, incluindo-se aí as visões que têm sobre a profissão e seu projeto ético-político. Esta consulta não significou, absolutamente, estabelecimento de juízos de valor individual ou de 
comparações sobre aqueles que detinham mais ou menos conhecimentos, afinidades e/ou chances de atingirem a conclusão do curso. Visei, tão somente, perscrutar, notar e discutir, à luz das perspectivas dialética e hermenêutica, as recorrências e contradições das visões e discursos, que representam heranças históricas da pluralidade de idéias que constituem a própria profissão. Obviamente, o espaço acadêmico não é a única fonte de construção das diretrizes e paradigmas profissionais. A construção de uma profissão é processo dialético e não-linear, portanto aberto, dinâmico e permanente, que incorpora as contradições decorrentes da inserção desta atividade e dos profissionais na própria sociedade. Contudo, a escolha de estudantes do primeiro semestre (calouros e calouras) deveu-se a dois motivos principais: $i$ ) o que se buscou neste trabalho foram os motivos e percepções que levaram a escolher o curso, não as perspectivas teóricas que cada um pode adotar a posteriori, bem como as visões acerca da profissão. Questionamentos deste nível feitos a formandos, por exemplo, estariam sujeitos a reinterpretações advindas das influências experimentadas durante a graduação ${ }^{1}$; ii) refletir a escolha do curso pôde representar um importante feedback para os próprios estudantes, instigando-os a confrontar suas visões acerca da profissão com o conteúdo das disciplinas específicas, especialmente da matéria de Introdução ao Serviço Social. A segunda questão que me motivou a procurar respostas foi: será que as visões tradicionais estereotipadas e superficiais - de assistencialismo, filantropia, voluntariado, etc - acerca da profissão estão presentes no ideário daqueles que iniciam o curso ou estes já têm claros as diretrizes e o atual projeto ético-político do Serviço Social ao escolher o curso? ${ }^{2}$

Creio que dois motivos centrais tornam relevante este estudo. Destacam-se:

a)

A grande importância do tema não tem sido acompanhada de estudos e publicações que tratam da escolha da profissão de assistente social em específico, notadamente os escritos por profissionais da área. Subsistem apenas, a guisa de orientações vocacionais, material muito geral que não

\footnotetext{
${ }^{1}$ Embora diversificado, o discurso dos estudantes que já percorreram os primeiros semestres do curso tende a agrupar alguns consensos básicos em termos de perspectiva crítica (de predominância marxista) em relação a estas questões e de alguns outros temas, talvez em decorrência das leituras, aulas e vivências acadêmicas. Mas qual é a tendência ideológica dos que chegam à universidade em relação a estas questões? Como entendem o papel do Serviço Social na divisão social do trabalho? Quais as principais motivações ou ideais que levaram à escolha do curso: seria vocação, solidariedade, experiências anteriores na ação social e/ou militância política, acaso, conseqüência do aumento de possibilidades no mercado de trabalho ou um pouco de tudo isto?

${ }^{2}$ Não estou supondo, ao buscar as respostas junto aos calouros, que estes não tinham ou não chegaram à universidade com algum referencial teórico-metodológico ou postura crítica acerca das relações sociais no capitalismo, por exemplo. Também não significa afirmar que os “veteranos” tenham tudo muito claro. A curiosidade estava em perceber como os primeiros relacionavam suas posições/convicções ideológicas com a escolha do curso, e se tais influências coadunavam com o atual projeto ético-político da profissão.
} 
contempla aprofundamentos necessários e mais esclarecedores acerca da profissão. A discussão teórica sobre a natureza e identidade do Serviço Social e mesmo pesquisas acerca do perfil dos assistentes sociais é considerável, mas não se incluem, na maioria dos casos, os estudantes do curso de Serviço Social e as suas motivações, aspirações e opiniões sobre a profissão, o que será referência útil para os que alçam cursar a faculdade.

b) Possivelmente o estudo constituirá um estimulo para aqueles que desejam realizar pesquisas mais aprofundadas, o que indubitavelmente possibilitará conhecer melhor o perfil dos estudantes contemporâneos de Serviço Social em suas expectativas, percepções e paradigmas, algo que, por sua vez, também abre perspectivas para outros estudos de comparação histórica entre as concepções de décadas anteriores com as atuais, notando-se mudanças, recorrências e transformações, isto é, aquilo que permaneceu mudando e o que mudou permanecendo na profissão em sua evolução.

O trabalho está dividido da seguinte maneira: no primeiro capítulo apresenta-se a abordagem teórico-metodológica que orientou o estudo, bem como a conceituação de algumas das categorias centrais a que recorri nesta análise ${ }^{3}$, quais sejam: trabalho, identidade profissional e vocação. A perspectiva do materialismo histórico dialético orienta grande parte do estudo, mas não constitui a única fonte teórica da pesquisa ${ }^{4}$. Em termos metodológicos, vali-me das contribuições da tradição crítica da dialética marxista e da análise hermenêutica de profundidade (voltada para análise das estruturas dos textos e argumentações), utilizando-as em contextos de pesquisa qualitativa. A preferência pela pesquisa qualitativa não significou exclusão de métodos quantitativos, mas caminho metodológico mais adequado para explorar com maior profundidade e discernimento crítico algumas questões que não são mensuráveis, mas que, pela sua importância histórica e intensidade, indubitavelmente são capitais ao tema de estudo. Os dois capítulos seguintes apresentam um breve panorama histórico e crítico dos primórdios do Serviço Social, bem como suas vinculações a interesses de classe, funções, opções teóricas e doutrinárias hoje tidas por conservadoras e, mais adiante, posteriores rupturas teórico-metodológicas (sobretudo o chamado movimento de

\footnotetext{
${ }^{3}$ Ao longo dos demais capítulos outras categorias vêm necessariamente à tona nas discussões, como: questão social, capitalismo, neotomismo, positivismo, filantropia, voluntariado, projeto ético-político, terceiro setor, etc.

${ }^{4}$ Por exemplo, o conceito de vocação não é contemplado nem por Marx nem pela tradição marxista de forma aprofundada. Todavia, é importante substrato para o entendimento das atividades do Serviço Social em seus primórdios, sobretudo pela ótica da neotomismo, que vincula o exercício profissional ao exercício da missão de caridade dos leigos.
} 
Reconceituação, a influência do marxismo e da fenomenologia). Argumenta-se, conforme a tese de José Paulo Netto ${ }^{5}$, que a análise da emergência histórico-social do Serviço Social não pode se esgotar na idéia de conseqüência da mera especialização da caridade demandada pelas contradições entre capital e trabalho - isto é, ao surgimento da questão social -, mas às peculiaridades e exigências que o capitalismo de corte monopólico infligiu às relações entre Estado, mercado e sociedade, desencadeando uma série de condições que fizeram surgir tal profissão, o que veremos especialmente no caso do Brasil ${ }^{6}$. 0 quarto capítulo volta-se para a contemporaneidade e os desafios postos ao projeto ético-político assumido pelo Serviço Social (portanto, desafios dos assistentes sociais) frente à ofensiva neoliberal. Neste contexto, o avanço do chamado terceiro setor, do voluntariado e também dos espaços abertos aos assistentes sociais nesta seara são vistos com cautela e crítica, porquanto podem representar, para além de avanço da solidariedade social e, para nós, oportunidades de empregos, estratégia ardilosa de refilantropização da questão social, desmonte da ação do Estado e ocaso dos direitos sociais conquistados. $\mathbf{O}$ último capítulo (quinto) contempla a apresentação e análise dos resultados da pesquisa realizada junto aos estudantes de Serviço Social do 2\%/2006 da Universidade de Brasília (UnB). A hipótese inicial de que a escolha do curso estaria de algum modo vinculada à herança das diversas concepções históricas e ideológicas ligadas à associação do perfil profissional do assistente social relacionado à ajuda assistencialista, mera militância política, solidariedade, caridade, desprendimento pessoal ou filantropia - e outros temas correlatos - foi confirmada, revelando que, ao lado de melhor divulgação, o projeto ético-político do Serviço Social tende a não atingir ainda boa visibilidade ou clareza de compreensão por boa parte da sociedade $^{7}$, embora a prática cotidiana da categoria profissional e a sua produção científica busquem construir concepções diferentes destas.

Destarte, ao comemorarem-se oficialmente os setenta anos da profissão no país e, na aurora de um novo século, cabe-nos refletir sobre os motivos que levam tantas pessoas a aspirar uma profissão que, salvo exceções, não traz prosperidade financeira, status quo ou condições tranqüilas de trabalho, ainda mais se considerado o cenário de precarização, desemprego e desmonte de direitos que o capitalismo vem impondo, ainda que em nosso caso pesquisas indiquem tendencial aumento de emprego (GRAVE, 2000).

\footnotetext{
${ }^{5}$ Cf: NETTO, J. P. Capitalismo monopolista e serviço social. São Paulo: Cortez, 1992.

${ }^{6}$ Destarte: “a busca fundamental é, portanto, pensar historicamente o Serviço Social brasileiro em suas conexões com o capitalismo (...). O que se busca é desvendar a odisséia por ele percorrida e, nela, compreender as formas históricas de manifestação da identidade, através de suas conexões com a consciência e com a prática social dos agentes" (MARTINELLI, 2006: 25).

${ }^{7}$ Porque, via de regra, os estudantes vêm justamente com a visão geral que a sociedade tem da profissão.
} 


\section{0 - Abordagem teórico-metodológica}

Este capítulo encontra-se subdividido em dois momentos principais: primeiramente são apresentados os fundamentos teóricos que se constituíram enquanto categorias principais de nossa análise. Predominam, como poderão notar-se, elementos da tradição marxista, porquanto estes contemplam de uma maneira mais avançada as discussões que foram pretendidas neste estudo. A exceção dar-se-á em relação ao debate acerca do conceito da escolha profissional como vocação, que encontra enfoques mais aprofundados na Psicologia e Antropologia Filosófica. Este último conceito pode parecer como um "estranho no ninho" se percebido em comparação com o conjunto dos outros fundamentos, mas tornou-se indispensável elucidá-lo devido à grande recorrência com que ele apareceu nas pesquisas realizadas junto aos calouros. Por uma questão de melhor adequação contextual, ao longo dos outros capítulos também serão acrescentadas novas categorias e conceitos, concernentes aos temas discutidos. A segunda parte do capítulo apresenta as metodologias empregadas para a consecução dos objetivos, destacando-se a conjugação de dois métodos muito importantes para as ciências humanas: a dialética marxista e a hermenêutica de profundidade, ambas usadas em pesquisas qualitativas.

\section{1 - Fundamentação teórica: categorias gerais de análise}

Dada a heterogeneidade de perspectivas e convicções dos nossos sujeitos de pesquisa, bem como a complexidade do nosso objeto de estudo, não seria possível recorrer somente a uma fonte teórica de explicação, porquanto isto poderia significar em alguns momentos enquadramento ou transposição inadequada de conceitos fora do sentido empregado pela pessoa em seu ponto de vista e análise. Todavia, isto não quis significar de modo algum a alegação de pretensa neutralidade ou posição acrítica perante as proposições realizadas, mas apenas respeito ao momento dialético de síntese dos sujeitos por parte do pesquisador. As categorias fundamentais para a consecução do estudo foram: a) trabalho; b) identidade profissional; c) vocação; d) solidariedade e voluntariado; e) projeto ético-político. As duas últimas categorias supracitadas - quais sejam: solidariedade / voluntariado e projeto ético-político profissional - serão trabalhadas mais adiante, nos capítulos específicos destes temas. As influências do neotomismo, do positivismo, da perspectiva funcionalista e da fenomenologia também são trabalhadas em outros capítulos, para entendermos melhor a história e a recorrência destas tradições na gênese e ao longo dos primeiros anos do percurso do Serviço Social no país. 


\section{a) Trabalho}

Trabalho, entre outras definições, pode ser entendido sob a perspectiva marxiana de categoria ontológica estruturante e transformadora do homem (ser social) e da natureza, que repercute num contínuo e dialético desenvolvimento das capacidades humanas, das forças produtivas, da complexidade social e do processo dinâmico de gênese, re-criação e desenvolvimento da reprodução social (RAMOS, 2000). Pelo processo de trabalho, os homens transformam a realidade, transformam-se a si mesmos e aos outros homens, desenvolvendo capacidades que passam a orientar fortemente outras relações sociais. Desenvolve também as mediações, tais como consciência, linguagem, simbologias e conhecimento, assim como a instrumentalidade e aqueles instrumentais necessários para alterar e/ou aperfeiçoar as condições objetivas e subjetivas ${ }^{8}$ existentes na sociedade (GUERRA, 1999). Trabalho é, neste sentido, uma determinação ontológica fundamental, isto é, imperativa mediação intrínseca ao próprio desenvolvimento do intercâmbio entre os seres humanos e a natureza. A finalidade (teleologia) desta perspectiva natural das relações de trabalho é a preservação das funções vitais da reprodução individual e social, constituindo-se sistemas de mediações de primeira ordem (ANTUNES, 1999) ${ }^{9}$.

Todavia, no capitalismo, o trabalho - bem como todas as outras dimensões e atividades sociais - é estruturalmente subordinado aos interesses da lógica do capital, aonde o valor de uso das coisas vai sendo cada vez mais submetido ao seu valor de troca $^{10}$ (mercantilização), gerando um penoso e explorador processo de produção de excedentes (mais-valia e/ou lucro). Estes excedentes, por sua vez, são apropriados pelos detentores dos meios de produção e expropriados dos trabalhadores (MARX, 1994). Estes últimos vendem a sua força de trabalho em troca de um salário ou de benefícios, mas ficam submetidos, tal qual as mercadorias, à exploração e desmandos do sistema: "No

\footnotetext{
${ }^{8}$ Condições objetivas: são aquelas relativas à produção material da sociedade. São condições postas na realidade material, como por exemplo, a divisão do trabalho. Condições subjetivas são aquelas relativas aos sujeitos, às suas escolhas, ao grau de qualificação e competência, aos referenciais teóricos, etc (GUERRA, 1999).

${ }_{9}^{9}$ Ainda que o trabalho livre seja algo inviável no capitalismo, vale citar o que disse o Papa Paulo VI na encíclica Populorum Progressio: "o trabalho só é humano na medida em que permanecer inteligente e livre" (1967: 25).

${ }^{10}$ Geralmente, conceitua-se valor como sendo a quantidade de trabalho incorporada na mercadoria, pois só existe valor quando existe a incorporação do fator trabalho no produto. $\mathrm{O}$ valor de algo pode ser decomposto em valor de troca e valor de uso. O primeiro caso ocorre quando se concretiza o intercâmbio entre duas mercadorias. O segundo caso acontece quando uma mercadoria tem qualidades intrínsecas que servem ao ser humano. A utilidade de uma coisa transforma essa coisa num valor-de-uso. O valor-de-troca surge, antes de tudo, como a relação quantitativa, a proporção em que valores-de-uso de espécies diferentes se trocam entre si, relação esta que varia constantemente com o tempo e o lugar. O que faz de uma coisa um valor-de-uso é a sua utilidade. O trabalho útil, dessa forma, é aquele cuja utilidade se patenteia no valor-de-uso do seu produto ou cujo produto é um valor-de-uso. O trabalho que produz valor-de-uso é individual e de natureza qualitativa, possuindo, por isso, características particulares. E é este tipo de trabalho (que produz valor-de-uso) que Marx denomina trabalho concreto. Por outro lado, o trabalho que produz valor-de-troca é abstrato (MARX, 1994).
} 
processo de trabalho capitalista, o trabalhador opera sob o comando do capitalista, e o produto resultante do processo de trabalho lhe pertence porque o trabalhador recebeu do capitalista o valor de sua força de trabalho em forma de salário" (RAMOS, 2000:64).Tal inversão de valores desencadeia, dentre outras coisas, a perda do sentido original do trabalho, isto é, a criação do valor de uso, tornando-se fonte de exploração e alienação. Intensifica-se o acirramento das contradições e antagonismos de classes, a alienação entre trabalhador e meios de produção e, logicamente, a concentração de rendas por poucos e profundas desigualdades sociais e miséria para a maioria ${ }^{11}$. Nesta perspectiva, o processo de trabalho passa a ter como finalidade essencial à expansão constante do valor de troca, e não mais somente o suprimento das necessidades pessoais e sociais. Trata-se, segundo Ricardo Antunes, da ascensão e sobreposição das mediações de segunda ordem em detrimento daquelas que chama de primeira ordem (ANTUNES, 1999).

Em meados da década de 1970 a crise internacional do padrão de acumulação de bases taylorista e fordista ${ }^{12}$ (estagnação econômica) e o desmonte do Leste Europeu (União Soviética) desencadeou mudanças e re-configurações na organização capitalista (sem alterar a essência), promovendo o acirramento da competitividade e precarização das relações trabalhistas. Tais alterações apoiaram-se nas idéias de flexibilização e reestruturação, chamadas de acumulação flexível, modelo japonês ou toyotismo ${ }^{13}$. De um modo geral, busca-se com este novo modelo: "uma flexibilidade no processo de trabalho, em contrapartida à rigidez da linha de produção, da produção em massa e em série; uma flexibilidade do mercado de trabalho, que vem acompanhada da desregulamentação dos direitos do trabalho, de estratégias de informalização da contratação dos trabalhadores; uma flexibilidade dos produtos, pois as firmas não produzem necessariamente em série; (...) e uma flexibilidade dos padrões de consumo" (IAMAMOTO, 1999:116).

\footnotetext{
${ }^{11}$ A reprodução da força de trabalho revela o lugar ocupado pela classe trabalhadora no capitalismo, pois: "reproduz também a situação de classe e as desigualdades sociais inerentes ao sistema capitalista, na dinâmica das lutas e forças sociais” (FALEIROS, 2000:77).

12“A estratégia de organização taylorista/fordista implica a produção em série e em massa para o consumo massivo, uma rígida divisão de tarefas entre os executores e planejadores, o trabalho parcelar fragmentado $e$ a constituição do operário-massa. Essa base de organização do processo de trabalho demarca o padrão industrial do pós-guerra, complementado com políticas anticíclicas levadas a efeito pelo Estado, impulsionadoras do crescimento econômico" (IAMAMOTO, 1999:115).

${ }^{13}$ Isto significa dizer que o toyotismo surge como proposta de um novo padrão de organização social da produção (mas sem abandono da essência do capitalismo), baseado "na nova racionalidade dos processos produtivos, não apenas devido ao uso intensivo da microeletrônica, generalizando as práticas da automação e da informatização, como, também, pela flexibilização dos processos de trabalho, determinando novas modalidades de produção, gestão e consumo da força de trabalho, provocando transformações no conteúdo, na qualidade e nas relações laborais” (KOIKE, 1999:104).
} 
Contudo, essas transformações no mundo do trabalho não podem ser vistas como crise da categoria trabalho de forma genérica, mas somente enquanto mais uma das tantas crises que o trabalho passa no interior do capitalismo: "em linhas gerais, a superprodução gerada em decorrência do acirramento da competição internacional engendrou em última análise a crise desencadeada nos anos 1970 e sentida até os dias atuais" (GRAVE, 2000:78). No livro Adeus ao Trabalho? Ricardo Antunes ressalta que é preciso recuperar a distinção marxiana feita entre trabalho concreto e abstrato. Explicando a distinção, diz: "De um lado, tem-se o caráter útil do trabalho, relação de intercâmbio entre os homens e a natureza, condição para a produção de coisas socialmente úteis e necessárias. É o momento em que se efetiva o trabalho concreto, o trabalho em sua dimensão qualitativa. Deixando de lado o caráter útil do trabalho, sua dimensão concreta, resta-Ihe apenas ser dispêndio de força humana produtiva, física ou intelectual, socialmente determinada. Aqui aflora sua dimensão abstrata" (ANTUNES, 1995:76). Ainda, segundo o mesmo autor, é apenas este último tipo de trabalho (abstrato) que se encontra atualmente em crise, notadamente quando se põe a questão da crise da centralidade da categoria trabalho. Sobre este tema, observa ainda Antunes que "trata-se de uma crise da sociedade do trabalho abstrato cuja superação tem na classe trabalhadora, mesmo fragmentada, heterogeneizada e complexificada, o seu pólo central" (idem: 80). A recusa, enfim, do trabalho abstrato, alienado e alienante, não significa que o trabalho deva ser desqualificado de maneira geral, pois enquanto trabalho útil ele "é um dos fundadores do ser enquanto 'ser social', e é por isso também, uma via possível para a emancipação humana sob o domínio da sociedade do capital" (ANTUNES, 1995:81).

\section{b) Identidade profissional do Serviço Social}

Posto isso, cabe discutir a própria natureza e identidade do Serviço Social como trabalho, avaliando se o seu caráter é eminentemente produtivo ou improdutivo de valor de uso ou valor de troca na divisão social do trabalho no sistema capitalista, bem como notar as inserções ambíguas da profissão nas relações entre Estado, mercado e sociedade no cenário contemporâneo, percebendo como estas mudanças também afetam ou reconfiguram a instrumentalidade e o modus operandi dos assistentes sociais.

De início, vale dizer que a discussão do caráter do Serviço Social como profissão que produz valor de uso ou valor de troca não parece estar definida, sendo questão polêmica entre muitos autores (RAMOS, 2000). Há, também, uma discussão acerca da prática 
profissional do assistente social como um processo de trabalho produtivo ou improdutivo ${ }^{14}$ : "porque essa recorrência, em Marx, é restrita ao trabalho produtivo de mais-valia. O Serviço Social, ao contribuir para a reprodução da força de trabalho, não se encontra incluído no trabalho coletivo de produção de mais-valia. Pensar o Serviço Social como trabalho implicaria que este fosse partícipe do processo de produção de mais-valia" (RAMOS, 2000:86). De outro lado, lamamoto considera que a profissão participa na produção do valor de troca e da mais-valia: o fato de o assistente social ser um trabalhador assalariado o inclui no universo da mercantilização. A autora argumenta que o Serviço Social se reproduz "como um trabalho especializado por ser socialmente necessário: produz serviços que atendem a necessidades sociais, isto é, tem um valor de uso, uma utilidade social. Por outro lado, os assistentes sociais também participam, enquanto trabalhadores assalariados, do processo de produção e/ou distribuição da riqueza social. Seu trabalho não resulta apenas em serviços úteis, mas tem efeitos na produção ou distribuição da riqueza social, isto é, do valor e da mais-valia" (IAMAMOTO, 1999:114).

Polêmicas à parte, parece haver uma tendência de consenso no debate teórico contemporâneo ao se conceber o Serviço Social como profissão inserida na divisão social e técnica do trabalho: "O Serviço Social é reconhecido como um tipo de especialização do trabalho (...). Tal abordagem supõe circunscrever o exercício profissional no âmbito das relações entre o Estado e a sociedade civil, no marco de uma sociedade de classes" (IAMAMOTO, 1999:113). Isto significa que, como as outras profissões, o Serviço Social não é categoria abstrata, que opera independentemente de determinações histórico-sociais verificadas nas especificidades contextuais (país, região...), o que implica a busca do seu entendimento somente se considerando o contexto dos processos econômicos e políticos vigentes. Essa análise encarnada na realidade constitui-se como variável indispensável para entendermos os sentidos, as ações e os caminhos da profissão (ALAYÓN, 1995). Logo, a participação do Serviço Social no âmbito da divisão social do trabalho em contextos capitalistas repercute - por conseqüência das contradições e antagonismos de classes típicas do próprio capitalismo - em exercício profissional marcado pela mediação dinâmica polarizada pelos interesses das duas classes fundamentais - isto é, da burguesia e do proletariado -, embora tendendo historicamente a ter sido cooptada pelos interesses da classe que tem uma posição dominante (FALEIROS, 2000; MARTINELLI, 2006) ${ }^{15}$.

\footnotetext{
${ }^{14}$ As expressões ‘produtivo' ou ‘improdutivo' apenas caracterizam a posição do trabalhador no processo de valorização do capital.

${ }^{15}$ Pois pelo transito permanente pela relação capital-trabalho, riqueza-pobreza, a profissão, por força de sua identidade atribuída e como estratégia do próprio capitalismo, acabou por responder mais prontamente às demandas do capital, acentuando-se a sua característica de instrumento de reprodução das relações sociais de produção capitalista (MARTINELLI, 2006).
} 
Devido ao "berço" capitalista (monopolista) de nascimento, nem sempre a identidade profissional do Serviço Social esteve vinculada claramente aos interesses de emancipação e cidadania das classes trabalhadoras enquanto projeto ético-político e finalidade perene da categoria profissional. Entrelaçado pelas influências ideológicas dos métodos exportados para os países capitalistas periféricos pelos Estados Unidos e países europeus - como as orientações para trabalhos de caso, grupo e comunidade -, dos princípios humanistas cristãos, do positivismo e de tantas outras doutrinas e práticas que remetiam e/ou reduziam a profissão ao assistencialismo e filantropia (ALAYÓN, 1995), por muito tempo o Serviço Social não pôde construir uma identidade profissional própria, mas apenas reproduziu os mecanismos de alienação e as orientações capitalistas, algo que até hoje se faz sentir na imagem por vezes distorcida (e assistencialista) ou confusa que a profissão tem perante a sociedade: “Absorvidos pela tecnoburocracia e enclausuradas nas instituições para darem operacionalidade a propostas políticas de prática profissional de cuja elaboração não haviam participado, ora a serviço da classe dominante ora a serviço do Estado burguês, os assistentes sociais tiveram roubados (sic) os seus espaços de construção de identidade. Assim, acabavam por sucumbir aos ardis do capitalismo, ratificando e sancionando, pela continuidade do uso, a identidade que por ele Ihes fora atribuída. Num verdadeiro fetichismo, a identidade atribuída ganhava um estatuto ontológico próprio, marcando sua prática profissional“ (MARTINELLI, 2006:156).

Por outro lado, é justamente o perfil ambivalente - e mesmo contraditório - do exercício profissional do assistente social em meio ao capitalismo que se constitui como identidade profissional do Serviço Social. E, mais do que contradição, essa característica encerra a possibilidade dialética concreta da profissão desvencilhar-se das suas raízes e práticas historicamente burguesas, pois: "Embora constituída para servir aos interesses do capital, a profissão não reproduz monoliticamente necessidades exclusivas do capital: participa também de respostas às necessidades legítimas de sobrevivência da classe trabalhadora, enfrentadas, seja coletivamente, através dos movimentos sociais, seja na busca de acesso aos recursos sociais existentes, através dos equipamentos coletivos que fazem face aos direitos sociais do cidadão" (IAMAMOTO, 1995:100). E esta possível mudança de sentido do exercício profissional vai permitindo uma ruptura - um processo construído cotidianamente - com a tendência à funcionalidade da manutenção da ordem burguesa vigente, desde que se tenham claras e não sejam abandonadas as referências teóricas e finalidades orientadoras do projeto ético-político contemporâneo, que conclama o Serviço Social a contribuir no processo de superação do capitalismo (GUERRA, 1999). 


\section{c) Vocação}

A inclusão da categoria vocação neste estudo pode parecer, à primeira vista, algo desconexo com o restante das outras categorias teóricas, claramente vinculadas à teoria crítica marxista ${ }^{16}$. Também pode suscitar uma hipotética alusão ao caráter tradicional - e, para o bem da verdade, bastante presente nos primórdios da profissão - de associação deste termo ao sentido teológico de "chamado" ou "missão". Contudo, esclareço desde já que não é este o sentido atribuído a esta palavra nesta monografia, até mesmo porque o Serviço Social não é vocação de cunho religioso (tal qual o sacerdócio) ${ }^{17}$, mas profissão inserida na divisão social e técnica do trabalho. O que pretendo com a inclusão desta categoria é buscar, à luz das contribuições de autores da Psicologia e da Antropologia Filosófica, possíveis subsídios para discutir criticamente a existência (ou não) de uma vocação (ou afinidade eletiva) que induza à escolha do Serviço Social como profissão, recorrência freqüente nas discussões dos estudantes e objeto de análise deste estudo.

Mas, se realmente existe, o que é e como se manifesta uma vocação profissional?

De forma geral, o conceito vocação tem sido entendido de modo reducionista. $\mathrm{Na}$ maioria das vezes aparece identificado tão somente com o sentido de escolha profissional ou, por outro lado, nas religiões, como um chamado. Julián Marías denomina de vocações parciais aquelas que se referem a alguns aspectos ou facetas da personalidade comuns a várias pessoas, portanto, genéricas. Segundo este autor, a vocação no sentido mais profundo e radical envolve a pessoa em sua totalidade e singularidade: "a vocação concreta é única, rigorosamente pessoal; é a vocação em que cada um consiste mais propriamente, e coincide com o eu de cada um" (MARÍAS, 1984:69).

De fato, não são decisões individuais o lugar e a época do nascimento, a família, as características físicas, etc. Tais circunstâncias são impostas e é a partir delas que a vida de cada um se configura de início. Porém, a liberdade da escolha e decisão incide no modo, no como cada pessoa constrói a sua história e na maneira dela relacionar-se com os meios dados: "O que se escolhe na vida é algo diferente: não o que se é, e sim quem se vai ser. Há que se precisar um pouco mais: não escolho quem tenho que ser, e sim quem e de que maneira vou ser; em outras palavras, qual vai ser a trajetória efetiva de minha vida, na medida em que permite a circunstância" (MARÍAS, 1983:24).

\footnotetext{
${ }^{16} \mathrm{O}$ conceito de vocação não é contemplado nem por Marx nem pela tradição marxista de forma específica. Marx fala da vocação humana ao trabalho como ontologia, mas algo geral a todos. Também Gramsci constrói o conceito de intelectual orgânico, mas não o faz com o sentido de discutir a vocação de cada pessoa e de cada profissão.

${ }^{17}$ Não se trata de menosprezo irônico à vocação entendida no sentido da Teologia, algo mui admirável e digno, mas apenas adequação da utilização deste termo vinculado ao mundo do trabalho profissional.
} 
No caso da vocação profissional - que supõe a escolha de uma carreira profissional, bem como seus cumprimentos - devem estar subordinados, então, a afirmação de quem a pessoa é e quem ela deseja ser: é este 'alguém' que dá consistência e significado para o que vai ser realizado (MONDIN, 2003). Este conjunto de características antropológicas da vocação humana possibilita aprofundar temas relacionados ao caminho vocacional, que são comumente entendidos apenas a partir da perspectiva hedonista e redutiva, como quando se trata dos conceitos de auto-realização, felicidade e até mesmo do sentido do trabalho. O conceito de auto-realização, modernamente identificado como conquista de satisfação, sucesso ou prazer individual, tem sido cada vez mais valorizado e, ao mesmo tempo, mal compreendido. O enfoque consumista e degenerativo ditado pelos padrões das relações societárias de cariz capitalista têm colocado a busca de realização de maneira direcionada somente a aspectos parciais do homem, a ponto de muitas vezes se confundir realização como sinônimo de sucesso profissional, de status ou prosperidade advinda do exercício profissional. Considera-se "realizado" quem atingiu estes objetivos ou está em pleno desenvolvimento dos planos estabelecidos para $\mathrm{si}^{18}$. Esta perspectiva é uma distorção do sentido original do trabalho (valor de uso), vinculado à expressão da singularidade do ser, daquilo que há de criativo e original no ser humano (MARX, 1994).

Certamente, o momento da opção profissional revela-se como dotado de uma considerável dificuldade de escolha entre os jovens (também entre pessoas já adultas) que pretendem ou já ingressaram nas diversas faculdades ou escolas profissionalizantes. Estas dúvidas quanto à escolha da profissão já foram constatadas por especialistas em orientação vocacional, pesquisas acadêmicas e mesmo pela grande imprensa ${ }^{19}$. Diversas teses e/ou teorias arriscam a procura de explicações (causas) para tais dificuldades. Uma das mais correntes refere-se à associação do crescimento da evasão nos cursos universitários ao que se poderia chamar de "crise de valores e de ideais" ou ainda à forte

\footnotetext{
${ }^{18}$ Ao tratar do tema da auto-realização, São Tomás “refere-se a um processo levado a cabo livre e responsavelmente e que incide sobre o nível mais fundamental, o do ser-homem” (LAUAND, 1993:40). Este processo está dirigido ao máximo das possibilidades humanas, ao ultimum potentiae: "o máximo que se pode ser enquanto homem, a realização ao máximo (ultimum) do que somos, do que estamos chamados a ser (potentiae)” (LAUAND, 1988:27). Isto significa que a autorealização do homem é construída durante toda a vida, num movimento dinâmico contínuo, onde constantemente o homem experimenta sua existência como um 'ainda não' ou um constante tornar-se 'vir-a-ser'. Assim, o homem está sempre a caminho de sua plena realização: é um caminhante, um peregrino que se encontra em um percurso: “outro não é o sentido do conceito de 'status viatoris'. Existir como homem significa estar sempre 'no caminho” (PIEPER, 1969, p. 18).

${ }^{19}$ Por exemplo: nos resultados de uma pesquisa realizada em 1992 com alunos de graduação da Universidade de São Paulo, sob a coordenação da Professora Dr $^{\text {a }}$. Maria de Lourdes Ramos da Silva, apurou-se que: "acentua-se a significativa porcentagem de alunos dos últimos anos que, se lhes fosse possível voltar novamente ao momento do vestibular, não escolheriam novamente o mesmo curso”. (SILVA, 1992:99). A evasão de cursos universitários também tem aumentado: quase a metade dos alunos que entram na faculdade a cada ano no Brasil desiste do curso (cf. Revista Veja, de 20/08/97), gerando prejuízos não apenas pessoais mas, também, sociais e econômicos, pois afetam especialmente as instituições públicas, cujos recursos acabam por não serem adequadamente aproveitados.
} 
influência do "relativismo" em nível das sociedades. Em última instância, isso significa dizer que o cenário pós-moderno, alimentado pelo princípio filosófico da incerteza e da complexidade não-linear (DEMO, 2001) estaria provocando nas pessoas - sobretudo nos jovens - crescente instabilidade e mesmo superficialidade em vários aspectos, abarcando desde os simples relacionamentos sociais do cotidiano ("síndrome do descartável") até às decisões mais importantes, como a escolha de uma profissão, por exemplo. Destarte, a sociedade contemporânea, em grande parte, revelaria muita insegurança e incerteza quanto a valores. Em termos antropológicos, não havendo pontos de referência estáveis, gera-se crise e confusão de identidade, tornando muito difícil para o homem atual identificar, em última instância, o que realmente lhe "vale a pena" e, ato contínuo se dedicar a isto de forma duradoura. Filosoficamente falando, o afastamento das questões mais essenciais - como o porquê da existência, um sentido ou causa à qual entregar a vida, etc -, estaria gerando abandono ou inexistência de critérios para orientar e sustentar decisões ou ações: "a modernidade destruiu a metafísica do ser e terminou autodestruindo a metafísica do sujeito. Resta uma débil ontologia na qual a realidade é substituída por sua representação. (...) Diante do vácuo do simples rechaço, a educação precisa 'encontrar o fundamento' tanto para uma compreensão da realidade quanto para orientar e justificar as nossas próprias ações" (HOZ, 1988:119). Para a Psicologia, esta dificuldade do homem contemporâneo de tomar consciência de si mesmo, de se posicionar diante da realidade e a experiência freqüente de indecisão são conseqüências de uma mentalidade superficial e consumista que, negligenciando a necessidade destes fundamentos, não favorece a descoberta de valores, nem permitem ou geram autêntico desenvolvimento humano. Não havendo clara hierarquia de valores, a postura assumida perante situações que exigem soluções imediatas tende para a relatividade (ou relativismo), sem aprofundamento reflexivo maior sobre a razão das escolhas e atitudes a serem assumidas (MONDIN, 2003).

A segunda linha de raciocínio (que na verdade também se relaciona à primeira) está mais fundamentada pela questão econômica e trabalhista, atribui uma possível crise vocacional às instabilidades e vicissitudes da economia e do mercado de trabalho. As formas atuais de organização do trabalho - de acumulação flexível e contratos precários desencadeariam relações e exigências de manutenção da empregabilidade e ocupação profissionais sempre mais competitivas e em rápida transformação (ANTUNES, 1999), o que demandaria definição profissional cada vez mais precoce e, ao mesmo tempo, oferta de uma crescente disponibilidade de mão de obra (exército industrial de reserva). Para os jovens, cada vez mais novos ao serem solicitados a uma definição neste universo 
profissional é necessário oferecer algo que transcenda as perspectivas instáveis e dramáticas do mercado. Esta urgência vem sendo vista por educadores, que apontam a necessidade de educar para o mundo do trabalho e não apenas para o mercado de trabalho ${ }^{20}$, embora também possa alocar-se aí certa 'naturalização' ou submissão à lógica capitalista: "Deve-se formar para o mundo do trabalho ou para o mercado de trabalho? Formar para o mundo do trabalho significa capacitar o educando a viver de forma cooperativa e útil na sociedade em que se insere; já formar para o mercado de trabalho é buscar fornecer mão-de-obra exigida pelo processo produtivo" (SILVA, 1998:115). Assim, ao realizar a escolha profissional dentro deste contexto pós-moderno, dinâmico e sempre mais instável - onde tudo que é sólido se desmancha no ar -, diz-se que o discernimento vocacional adequado é aquele que considera não estritamente a profissão e as oportunidades, mas a concebendo dentro de uma dimensão ampla e, ao mesmo tempo essencial (identidade, projeto ético-político, diretrizes) estabelece pontes com a vocação de cada pessoa, bem como com seus valores e projetos. Tal perspectiva possibilita transcender o nível ocupacional inclusive para poder mantê-lo ou transformá-lo.

\section{d) Alguns equívocos sobre a vocação em Serviço Social}

Assistente Social: moça boazinha e de boa família, de conduta ilibada, que, sendo paga pelo Estado ou de modo voluntário - por compaixão - se dedica a ajudar os pobres. Pessoa solidária, que promove ou participa de ações filantrópicas ou de caridade.

Felizmente, esta não é uma definição adotada pela maioria daqueles que concluíram ou atualmente cursam a faculdade de Serviço Social. Não obstante, malgrado o tom um pouco exagerado (até mesmo caricato) da concepção supracitada, não seria grande polêmica afirmar que alguns destes predicados alocam distintas concepções estereotípicas acerca da identidade, significado, objeto, funções e projeto ético-político do Serviço Social, ecoando com freqüência em distintos espaços da sociedade - alguém diria no 'inconsciente coletivo' desta -, povoando desde noções mais superficiais e cotidianas do senso comum e estendendo-se até mesmo aos ambientes acadêmicos e institucionais.

Este "perfil vocacional" da profissão, marcado por ideais virtuosos de bondade e compaixão $^{21}$, implica uma série de entendimentos acerca da natureza e representação

\footnotetext{
${ }^{20}$ Não somente educar para o exercício da competência formal, mas, sobretudo, para a competência ética e política.

${ }^{21}$ Desde já, esclareço que não critico aqui tais ideais, indubitavelmente mui dignos, necessários e admiráveis para as relações humanas. A questão colocada é que estas e tantas outras virtudes não constituem necessariamente a motivação e o substrato do significado do Serviço Social, ainda mais em se tratando das atribuições que este assume - contraditórias, ambíguas e ambivalentes - na divisão social do trabalho no sistema capitalista. Neste sentido, o que se reivindica é a não-confusão das finalidades, objetivos e mediações estabelecidas na prática profissional do assistente social (orientada por critérios metodológicos
} 
social do Serviço Social. Mais do que simples estereótipos, estas figuras reproduzem, ainda na contemporaneidade, heranças históricas de vínculos do Serviço Social com as influências da visão de mundo burguesa e do pensamento humanista-reformista cristão (sobretudo a filosofia neotomista), que foi apropriado e modificado posteriormente pelos setores conservadores da sociedade para fins de legitimação discursiva da ordem capitalista monopólica então emergente (NETTO, 1992). Foi destas fontes que emergiram de formas mais ou menos intensas em cada país os substratos ideológicos e socioculturais para a associação (ou confusão) do trabalho do assistente social com as idéias de ajuda, serviço ao próximo (diakonia), doação e desprendimento pessoal, onde o assistente social assumiria a grave missão de qualificado executor técnico das atividades filantrópicas, ou ainda de um agente moderno destas. Tais construções mistificadoras acerca da vocação e ação profissional ficaram de tal modo enraizadas na sociedade que conseguiram - e ainda conseguem - muitas vezes encobrir o papel real que a profissão exerce no capitalismo ${ }^{22}$.

Outros entendimentos recorrentes emergem também a partir destas representações:

a) De que o Serviço Social é uma atividade típica de um gênero: feminino. De fato, uma pesquisa realizada em 2005 pelo Conselho Federal de Serviço Social sinaliza que o Serviço Social ainda é na atualidade uma profissão composta majoritariamente por pessoas do sexo feminino: 97\% dos assistentes sociais registrados são mulheres, assim como também são maioria as mulheres nas atividades assistenciais não relacionadas à profissão (CFESS, 2005). Esta é, indubitavelmente, uma marca histórica da profissão. Porém, mais do que a constatação desta realidade cabe refletir sobre os fundamentos antropológicos, sociológicos, econômicos e psíquicos que sustentam esta suposta afinidade vocacional e eletiva entre a mulher e a assistência: há uma série de construções culturais e simbólicas que atribuem às mulheres, no contexto das relações de poder entre os gêneros, perfis e atribuições tipicamente relacionadas aos ideais de gratuidade e maior doação em comparação aos homens; ao mesmo tempo e/ou em decorrência disso, as raízes históricas das práticas assistenciais - ao menos no Brasil - sinalizam que estas eram realizadas por mulheres, que se dedicavam à filantropia e caridade, sobretudo em pastorais e grupos da Igreja Católica (BOSCHETTI, 2003). Na esfera política, por sua vez, é historicamente recorrente a associação da assistência social às atividades de "primeiras-damas"

racionais, sistemáticos e técnicos) daquelas práticas voluntárias, eventuais e/ou de cunho religioso em que qualquer pessoa pode envolver-se, inclusive profissionais de qualquer formação.

${ }^{22}$ Sobre esta discussão cf: KISNERMAN, 1980; SILVA 1983; PEREIRA, 1996; CASTRO, 2000; MARTINELLI, 2006. 
e, mais recentemente, das ações sociais de "emergentes" e "socialites". Da mesma forma, parece subsistir ainda hoje no Serviço Social um silencioso mas persistente vínculo da profissão ao gênero feminino, não obstante todas as modernizações e rupturas advindas das revisões teórico-metodológicas e operacionais. Porém, mais do que evocar idéias de mito ou afinidades genéticas é interessante refletir: a escolha do Serviço Social é uma questão de gênero?

b) De que a prática profissional está associada ao caráter solidário (ou bondade) do assistente social: neste sentido, é vasta (ao menos na atualidade) a literatura que contesta tal pressuposto (ESTEVÃO, 1999), a começar pelos instrumentos jurídicos que definem as diretrizes e normas da profissão (a exemplo do Código de Ética) bem como da própria definição constitucional das políticas sociais enquanto direitos do cidadão e deveres do Estado. Porém, embora pareça claro à maioria da categoria, tal discernimento não parece nítido com tais distinções por grande parte dos usuários dos serviços, outros profissionais e mesmo entre certas autoridades públicas e políticas (FALEIROS, 2000). Também não é heresia afirmar que há assistentes sociais não preocupados em desfazer tal associação, pregando em suas práticas relações de cariz paternalista (PADILHA, 1988) ${ }^{23}$.

c) De que se trata de um trabalho que até voluntários podem fazer: sem contestar a nobreza de quem realiza trabalhos voluntários e/ou filantrópicos, cabe sempre lembrar que não se podem confundir as práticas assistenciais e focalizadas algumas até assistencialistas - com a política de assistência social, que é direito do cidadão e dever de implementação do Estado e cujo planejamento, operacionalização e avaliação devem ser realizados de modo exclusivo e legítimo por profissionais habilitados para tanto, dentre eles o assistente social.

d) Olhando-se de maneira crítica, o crescimento do chamado terceiro setor na década passada e nestes primeiros anos do século XXI encoberta, dentre outras coisas, a remercantilização e refilantropização da questão social, favorecendo a lógica neoliberal de diminuição da intervenção e gastos do Estado pela via das políticas sociais (MONTAÑO, 2002). Embora se avente que o terceiro setor apresenta novas oportunidades de inserção para o Serviço Social, diversificando e especificando demandas, ainda assim trata-se de ocupações marcadas pela tendência neoliberal de precarização, flexibilidade e instabilidade (GRAVE, 2000).

${ }^{23}$ Ou ainda: "Freqüentemente pode-se observar a prática de colegas que assumem a ideologia do serviço não como direito, mas como doação, e leiloam a outorga de serviços aos setores necessitados. Situam-se como fiscais ou censores extremamente severos diante das solicitações de prestação social” (ALAYÓN, 1995:73). 
Por outro lado, também subsistem, ao lado destes estereótipos e equívocos, outras construções - algumas até exageradas - acerca do perfil vocacional e da ação profissional dos assistentes sociais na contemporaneidade. Trata-se de associações ao viés político "transformador", "libertário", "militante" ou mesmo, de outro modo, do caráter meramente "reprodutor" da profissão. Todas estas figuras são herdadas das aproximações do Serviço Social à tradição teórica marxista, sobretudo a partir da década de 60 , com o movimento de Reconceituação (que será tratado mais adiante). E, ainda que representem importantes buscas de rupturas em relação à dita herança conservadora (NETTO, 1992), algumas destas idéias e/ou atribuições beiram a perigosa aproximação idealista do Serviço Social ao messianismo, utopismo, retórica revolucionária ou, de outra maneira, ao fatalismo. Sendo assim, também são prejudiciais na representação social da profissão, porquanto podem desembocar em extremos deslocados da realidade histórica e do caráter bipolar e contraditório da prática do Serviço Social na divisão do trabalho. Neste sentido, estas supostas visões 'progressistas' acabam não superando ou não diferindo das concepções voluntaristas da "ajuda" e do "servir" que citei anteriormente. Vejamos dois exemplos emblemáticos (e opostos) de construções da vocação dos assistentes sociais:

a) As discussões de Gramsci sobre o intelectual orgânico enquanto agente de transformação social (desenvolvimentismo), carecem de reparos e podas, seja pelo tom exagerado (quase messiânico) com que foi utilizado por muitos ${ }^{24}$, seja pela própria realidade de pequena burguesia ${ }^{25}$ dos assistentes sociais ou pela grande heterogeneidade de posturas profissionais. Destarte, o assistente social pode ser intelectual orgânico em potencial, mas não deve ser tido ingenuamente como alguém sempre vocacionado a organizar, dirigir e dar suporte técnico que favoreça o processo de amadurecimento da consciência das classes populares, um progressista ou revolucionário que só luta pelos direitos dos trabalhadores (lamamoto, 1996). Logo: "No entanto, o assistente social não é um educador popular - ou não esgota a sua identidade nesta classificação - nem cabe inteiramente nos limites da etiqueta do promotor social" (PALMA, 1993:165).

\footnotetext{
${ }^{24} \mathrm{Na}$ associação do compromisso com a classe trabalhadora de forma individualista: "Como era muito difícil pensar o cotidiano profissional e o compromisso com a população passando pelo materialismo dialético, muitas assistentes sociais passaram a confundir a prática profissional com a militância política. Para quem trabalhava na favela, o compromisso significava ir morar na favela, para quem trabalhava na indústria, comprometer-se era ir trabalhar na linha de montagem” (ESTEVÃO, 1999:41).

${ }^{25} \mathrm{O}$ caráter de pequena burguesia inclui também a possibilidade de cooptação. Tal idéia: "Refere-se a uma 'classe' de transição, espremida entre a burguesia e o proletariado, mas destinada, na expectativa de Marx e Engels, a se proletarizar, face à tendência concentradora do grande capital. Em termos ideológicos, porém, a pequena burguesia se identifica mais facilmente com a burguesia, à sombra da qual sobrevive. Seu problema fundamental é ser pequena” (DEMO, 1995:89).
} 
b) A crítica althusseriana das profissões enquanto meras reprodutoras da ideologia dominante junto à classe trabalhadora parecem desprovidas do senso dialético de unidade de contrários e correlação de forças. Ainda que a tendência histórica da profissão tenha sido favorável ao projeto da burguesia, o sentido da profissão não pode ser reduzido a isto, dadas as contradições e alternativas possíveis de sua inserção na divisão social e técnica do trabalho. Crer no sentido unicamente reprodutor das ideologias dominantes força-nos a conceber o trabalho dos assistentes sociais ${ }^{26}$ como fatalista, determinista e perverso (IAMAMOTO, 1995).

Diria Marx: "A exigência de abandonar as ilusões sobre a sua situação é a exigência de abandonar uma situação que necessita de ilusões" (apud IAMAMOTO, 1995:125).

\section{2 - Metodologia de trabalho}

Diz-se que a pesquisa qualitativa impõe-se sempre que se trate de temas que interessam mais pela intensidade do que pela extensão dos fenômenos, como é o caso, por exemplo, de categorias e fenômenos como participação, comunicação, aprendizagem, felicidade e satisfação pessoal (HAGUETTE, 1987; GADAMER, 1997; DEMO, 2001). O tema da escolha profissional perpassa ou inclui todas estas questões. Veio daí a necessidade de utilização de instrumentais e métodos qualitativos para encontrar aquilo que procuramos especificamente neste estudo: as motivações, os significados e sentidos mais profundos que estão por trás da escolha do curso de Serviço Social. Logo, foi a natureza do tema da escolha que fez necessário tornar preferencial um caminho de pesquisa qualitativa, porém, apoiada em alguns pontos por dados quantitativos. Partiu-se assim do pressuposto de que: "todo fenômeno qualitativo é dotado também e naturalmente de faces quantitativas e vice-versa. Entre qualidade e quantidade não existe dicotomia, pois são faces diferenciadas do mesmo fenômeno. Métodos quantitativos e qualitativos precisam ser tomados como complementares e como regra" (DEMO, 2001:8).

Quanto ao apoio de métodos quantitativos, cabe dizer que foi aplicado um questionário socioeconômico (vide anexo) para a busca de entendimento do contorno mais geral e estrutural do fenômeno pesquisado (SELLTIZ et alii, 1971), bem como para notar possíveis recorrências ou relações entre as condições materiais e as respostas obtidas dos estudantes. Ressalta-se que o levantamento quantitativo não possuiu aqui uma pretensão de generalização, até porque o universo de alunos pesquisados - apenas a turma de calouros do 2\%/2006 - não compôs amostra suficiente para fins estatísticos.

\footnotetext{
${ }^{26}$ E também conceber as instituições e políticas públicas como blocos monolíticos fechados e definitivamente burgueses...
} 
A fim de analisar, interpretar e reinterpretar o mais profundo e intensamente - dentro dos limites deste estudo - as mensagens e/ou significados contidos nos diferentes modos de argumentar, atitudes, gestos, silêncios e até mesmo nas similitudes e recorrências todas estas comunicações e/ou informações qualitativas em potencial - referentes ao nosso objeto de estudo, fez-se mister então a utilização conjugada de dois métodos de análise muito importantes para os estudos das Ciências Humanas: a hermenêutica e a dialética. A hermenêutica serviu como uma espécie de apoio técnico para a realização da análise dialética crítica. Vejamos a seguir cada um destes métodos com mais detalhes.

\section{a) A contribuição da Hermenêutica}

Hermenêutica é um ramo da filosofia que se debate com a compreensão humana e com a interpretação de textos escritos. A palavra deriva do nome do deus grego Hermes, considerado pela tradição mitológica como o mensageiro dos deuses, a quem os gregos atribuíam a origem da linguagem e da escrita e consideravam patrono da comunicação e do entendimento humano. O termo provém do verbo grego "hermēneuein" e significa "declarar", "anunciar", "interpretar", "esclarecer" e, por último, "traduzir". Significa que alguma coisa é "tornada compreensível" ou "levada à compreensão". Encontra-se desde os séculos XVII e XVIII de forma mais presente nos ambientes teológicos, no sentido de busca de uma interpretação correta e objetiva da Bíblia. Para Schleiermacher a hermenêutica não visa o saber teórico, mas sim o uso prático, isto é, a práxis ou a técnica da boa interpretação de um texto falado ou escrito. Trata-se aí da "compreensão", que se tornou desde então o conceito básico e a finalidade fundamental de toda a questão hermenêutica (apud BERGER, 1999). Foi brilhantemente definida de modo bem simples e profundo pelo Papa João Paulo II como caminho de "tornar claro o que se apresenta obscuro nos discursos e gestos" (JOÃO PAULO II, 2002:12). Neste trabalho, a utilização deste método justificou-se pelo fato de que ela possibilitou uma compreensão mais aprofundada dos sentidos e estruturas de argumentação contida nos textos obtidos junto aos calouros, onde são justificados a escolha do curso e o entendimento acerca deste. Em suma, a hermenêutica ajudou a: "saber olhar o que não se vê facilmente, apanhar as dobras do discurso, perambular em suas gretas sutis, flagrar contradições, acompanhar a rota da inteligência dos argumentos, tudo isso faz parte da percepção crítica, capaz de tanto mais valorizar o mundo simbólico quanto mais o questiona" (DEMO, 2001:43). Como referenciais teóricos e metodológicos utilizei autores fundamentais, como Paul Ricouer (1981), Hans-Georg Gadamer (1997), Jürgen Habermas (1989) e Apel (2000). 


\section{b) A contribuição da Dialética}

A dialética (predominantemente do materialismo dialético) foi usada como método de análise crítica das informações obtidas. Não que a hermenêutica fosse caminho acrítico de análise, mas a perspectiva dialética contempla melhor alguns aspectos, sobretudo ao enfatizar a questão da teoria social intrinsecamente associada à totalidade. Como uma das tantas referências ou definições existentes do método dialético, tomo que os elementos do esquema básico da dialética são a tese, a antítese e a síntese. A tese é uma afirmação ou situação inicialmente dada. A antítese é uma oposição à tese. Do conflito entre tese e antítese surge uma síntese, que é uma situação nova que carrega dentro de si elementos resultantes desse embate. A síntese torna-se uma nova tese, que contrasta com uma nova antítese gerando uma nova síntese, em um processo em cadeia infinito ${ }^{27}$. A filosofia descreve a realidade e a reflete, portanto a dialética busca não apenas interpretar, mas refletir e agir sobre/nesta realidade. Logo, os três momentos (tese, antítese e síntese) não são apenas um método, mas derivam da dialética mesma, da natureza das coisas. A teoria dialética alerta nossa atenção para as sínteses, identificando as contradições concretas e as mediações específicas que constituem o "tecido" de cada totalidade - uma unidade de contrários. A contradição é reconhecida como princípio básico do movimento pelo qual os seres existem (KONDER, 1987). A razão humana é, assim, dialética, porquanto: "incorpora a contradição, o movimento, a negatividade, a totalidade, as mediações, buscando a lógica de constituição dos fenômenos, sua essência ou substância. A razão dialética refere-se a uma lógica objetiva que os processos sociais portam e às condições que permitem a reconstrução desta lógica, pela via do pensamento" (GUERRA, 1999:61).

\section{c) Metodologia aplicada}

O percurso metodológico foi dividido em três momentos:

a) Análise sócio-histórica: com o objetivo de apreender e tentar reconstruir as condições sociais e históricas de produção, circulação e recepção das formas simbólicas; procurar entender o contexto histórico e cultural do sujeito da pesquisa, seu percurso de formação, sua visão e expectativas, a fim de entender de que modo estas variáveis influenciaram na sua escolha pelo curso de Serviço Social da Universidade de Brasília. Em suma, este momento visou principalmente: "alocar no espaço e no tempo os fenômenos pesquisados, tendo-se em mente que a história e a inserção social são

\footnotetext{
27 Tais elementos pertencem à dialética hegeliana. Contudo, Marx e Engels posteriormente os aproveitaram, mas retirando o tom excessivamente idealista que tinham e substituindo-os pelas perspectivas do materialismo histórico e dialético.
} 
partes da gênese e da explicação" (DEMO, 2001:52). Tratou-se da fase da análise quantitativa, obtida a partir dos questionários socioeconômicos.

b) Análise hermenêutica: levantamento de freqüências de termos e noções, posicionamentos, códigos de linguagem e modos de argumentação. Este momento pretendeu valorizar a questão da análise culturalmente plantada, que significa a postura de esforço para o entendimento do outro assim como o outro gostaria de ser entendido, valorizando assim o seu ponto de vista.

c) Análise dialética: (re)interpretação crítica. Fase do questionamento crítico: interpretação do fenômeno observado em tom desconstrutivo, para ir além do que se diz e das aparências do que se diz; se antes estava em jogo o ponto de vista do outro, agora se salienta o ponto de vista e referencial teórico próprio. Também se incorporaram aí contribuições do materialismo histórico, considerando que o modo de produção tem forte determinação sobre os fenômenos históricos e sociais, inclusive sobre as visões acerca das instituições, política, moralidade, religião e de muitas outras realidades.

Esclareço que estes estágios ou fases da pesquisa não se deram necessariamente nesta ordem ou de maneira isolada, sendo assim definidos somente para fins didáticos. Em termos de cronograma, o estudo desenvolveu-se em três momentos principais:

1) Estudo do referencial bibliográfico: finalidade de embasar-me melhor acerca das categorias de análise necessárias para o entendimento e debate das questões levantadas e demais fenômenos correlatos.

2) Encontros com a turma de calouros nas duas primeiras semanas de aula do $2 \% / 2006$, em dias acordados com a professora da disciplina de Introdução ao Serviço Social Nestas aulas foram explicadas as finalidades da pesquisa e foram distribuídos os questionários socioeconômicos (dados de renda, local de moradia, etc). Também foi solicitada a cada estudante a escrita de uma redação em prosa, onde cada um exporia o(s) motivo(s) que o levaram a escolher o curso de Serviço Social, manifestando também o seu entendimento acerca da profissão e, por último, o que pensa ser necessário (possíveis requisitos vocacionais) para tornar-se bom profissional.

3) Tabulação do questionário socioeconômico, análise crítica dos dados obtidos, orientações, escrita e revisão da monografia. 


\section{0 - A questão social e as origens do Serviço Social}

Este capítulo apresenta uma sucinta visão panorâmica ${ }^{28}$ da gênese e primórdios do Serviço Social, notadamente no contexto nacional, situando-a logicamente vinculada ao surgimento e manifestações da chamada questão social. Contudo, a análise aqui feita segue a tese de que a emergência da profissão não se vincula a uma mera conseqüência da especialização e/ou racionalização das ações caritativas e filantrópicas existentes, mas às exigências bem particulares que a transição do capitalismo de cariz concorrencial para a fase monopólica impôs às relações entre Estado, mercado e sociedade (NETTO, 1992).

\section{1 - Questão social, capitalismo monopolista e Serviço Social}

Constitui um consenso - já de algum tempo - entre as diversas tendências e manifestações teórico-metodológicas existentes no interior da categoria dos assistentes sociais a concepção de que o Serviço Social surge como profissão institucionalizada e socialmente legitimada a partir das mazelas e demandas colocadas pela questão social. Uma visão crítica mais apurada sobre a história da genealogia do Serviço Social neste processo aponta - e isto é fundamental para colocarmos desde agora - que: "A origem do Serviço Social como profissão tem, pois, as marcas profundas do capitalismo e do conjunto de variáveis a ele estão subjacentes - alienação, contradição, antagonismo -, pois foi nesse vasto caudal que ele foi engendrado e desenvolvido" (MARTINELLI, 2006:66).

Mas, o que vem a ser a chamada questão social?

Neste ponto, o consenso anteriormente citado não atinge a mesma amplitude. Porém, de forma mais genérica (sem explicitar diferenças de objeto) algumas definições aparecem como pistas para o melhor entendimento dos sentidos, significados históricos e políticos do fenômeno (o termo foi utilizado pela $1^{1}$ vez em 1830 ). Para José Paulo Netto, a questão social é "o conjunto de problemas políticos, sociais e econômicos que o surgimento da classe operária impôs no curso da constituição da sociedade capitalista. Assim, a questão social está fundamentalmente vinculada ao conflito entre o capital e o trabalho" (NETTO, 1992:13). Marilda Vilela lamamoto entende a questão social como "as expressões do processo de formação e desenvolvimento da classe operária e de seu ingresso no cenário político da sociedade, exigindo seu reconhecimento como classe por parte do empresariado e do Estado (...). Manifestação no cotidiano da vida social, da contradição entre o proletariado e a burguesia" (IAMAMOTO e CARVALHO, 1996:77).

\footnotetext{
${ }^{28}$ Seja devido às limitações de quem a tece (um graduando), seja porque não é este o objeto específico desta análise.
} 


\section{a) Antecedentes históricos da questão social}

Conforme vimos, a questão social emerge em meados do século $X I X$, a partir do ingresso da classe operária urbana no cenário político, exigindo o seu reconhecimento como classe por parte do Estado e do empresariado, além de outros tipos de intervenção, para além da filantropia e da repressão usuais. O Serviço Social, por sua vez, surge como profissão num contexto de transição do capitalismo competitivo ou concorrencial para o capitalismo monopolista (NETTO, 1992). Todavia, cabe relembrarmos os antecedentes estruturantes para ambos, tanto para notar os fatos que desencadearam a questão social como para entendermos as concepções teóricas e doutrinárias que orientavam a ação profissional das primeiras escolas e assistentes sociais do Brasil (MARTINELLI, 2006).

De fato, os problemas sociais (as misérias, pobrezas, explorações e expropriações) não constituem recorrência e exclusividade histórica a posteriori do surgimento do capitalismo (século XIX). Tampouco as primeiras ações assistenciais e esporádicas de cunho individuais e/ou coletivas remontam a este período. Desde as Confrarias do Deserto (3000 a.C $)^{29}$ e dos profetas do Antigo Testamento ${ }^{30}$ da Bíblia Sagrada, por exemplo, podemos notar a denúncia da existência de conflitos sociais causados pela exploração ou abandono daqueles que estavam mais vulneráveis no contexto econômico, social e cultural hebraico, destacando-se sobretudo as figuras de órfãos, enfermos, viúvas e estrangeiros. Filósofos da Grécia Antiga como Platão, Aristóteles, Sêneca e Cícero também refletiram acerca das diferenças sociais e, em alguns (poucos) casos, propuseram esboços das formas como entendiam que deveria acontecer a racionalização da chamada justiça distributiva (SUPLICY, 2002). Porém, ao menos para o mundo ocidental, foi o advento do Cristianismo e, conseqüentemente, da Igreja Católica, que representou o grande impulso para o avanço sistemático e expansão das práticas assistenciais. $O$ mandamento de Jesus Cristo de "amor a Deus, ao próximo e a si mesmo" e a sua incisiva mensagem da necessária prática da caridade (caritas) aos pequeninos (aliada à fé) como caminho para a salvação constituiu-se (e até hoje se constitui) como forte indutor de ações sociais (caritativas) por parte de instituições e leigos de todos os países ${ }^{31}$. Muitas congregações e pessoas religiosas destacaram-se pela caridade exemplar, como Santo Ambrósio, São Francisco de Assis, São Vicente de Paulo e Madre Tereza de Calcutá, por exemplo.

\footnotetext{
${ }^{29}$ Umas séries de ajudas esporádicas dispensadas àqueles que atravessavam os desertos, principalmente do Egito Antigo.

${ }^{30}$ Até então, não se trata da questão social. Confira como exemplo, os livros dos profetas Isaías, Oseías e Jeremias, bem como o livro do Êxodo, que relata explorações sofridas e a libertação do povo judeu do jugo egípcio, liderados por Moisés.

${ }^{31}$ Diz o papa Bento XVI: "Para a Igreja, a caridade não é uma espécie de atividade de assistência social unicamente, mas sim pertence à sua natureza e é manifestação irrenunciável de sua própria essência" (Deus caritas est: 25).
} 
Por outro lado, muitas explorações foram realizadas sob capas mistificadoras e distorcidas dos discursos de prática da caridade. Tais posturas representaram, mesmo por membros da alta cúpula da Igreja (bispos e cardeais) ${ }^{32}$, afastamento daquele sentido empregado por Jesus Cristo, estando mais relacionadas à perpetuação de mecanismos de poder, submissão (amansamento) e reprodução de servidões destinadas aos pobres. A homogeneidade (não-divisão) entre Igreja e Estado fez com que a primeira fosse por muitas vezes se ocupando muito mais de questões temporais de prestígio e poder, e, ato contínuo, ela foi: "distanciando-se dos pobres e aliando-se à burguesia. Não obstante continuasse a proclamar a importância da caridade aos mais humildes, suas propostas e ações só aprofundavam o fosso que os separava dos poderosos" (MARTINELLI, 2006:98).

Além do discurso da caridade, uma outra recorrência comum desde a Idade Média, sobretudo a partir dos séculos XVI e XVII, que marcou as ações de busca de resolução para os problemas sociais e as modalidades de respostas tomadas pelo Estado (notadamente dos países europeus) e classes dominantes foi a crescente tensão na relação entre trabalho, controle social e assistência. No livro As metamorfoses da questão social, Robert Castel (1998) aponta que a assistência social contemporânea (política pública) guarda resquícios das primeiras medidas benemerentes, e isto ajudaria a explicar a insistente permanência da confusão entre assistencialismo, assistência e filantropia. Foi também na Idade Média que as primeiras tentativas de tecnicização das ações assistenciais emergiram, manifestando-se principalmente pelos critérios de merecimentos fundamentados no pertencimento comunitário (domicílio) e na (in)aptidão ao exercício do trabalho. Em relação ao pertencimento comunitário, o autor cita o remoto século XVI, onde cada paróquia passou a ser responsável pelo cuidado de seus pobres. Tais medidas foram retomadas posteriormente pelas legislações de países europeus, destacando-se as chamadas Poor Laws (Lei dos Pobres) inglesas, que desembocaram na Lei Elisabetana de $1601^{33}$. Também as workhouses (casas de trabalho) estavam vinculadas ao critério de residência. Mendigos, 'problemáticos' e 'vagabundos' de uma região eram submetidos nestes locais à "correções" baseadas no regime de trabalho e oração (BOSCHETTI, 2003).

\footnotetext{
${ }^{32}$ Em termos humanos e institucionais, não cabe conceber a Igreja como um bloco monolítico. Visão dialética mais apurada evita os extremismos de percebê-la somente como mais um "comitê da burguesia” ou, por outro lado - como queria a chamada Teologia da Libertação - um espaço exclusivo dos oprimidos. A Igreja é, na verdade, santa e pecadora, porquanto é composta (em termos materiais) de pessoas humanas, ambíguas e ambivalentes em suas intenções e gestos.

33 "Embora predominantes em toda a Europa, as legislações seminais e freqüentemente citadas para retratar esta relação de tensão ou oposição entre assistência são as leis inglesas, que assumiram caráter mais sistemático. Elas se iniciam com o Estatuto dos Trabalhadores de 1349, e seguem com o Estatuto dos Artesãos (Artífices) em 1563, com as leis dos pobres elisabetanas que se sucedem entre 1531 e 1601, a Lei de Domicílio (Settlement Act) de 1662, o Speenhamland Act de 1795 e a Lei Revisora das Leis dos Pobres (Poor Law Amendment Act) em 1834” (BOSCHETTI, 2003:53).
} 
O conjunto das legislações pré-capitalistas que se espalharam pela Europa antes da Revolução Industrial já explicitava - além do avanço do processo de pauperização das massas camponesas e dos distritos urbanos - a existência de uma forte tendência dialética de tensão e atração entre trabalho, apontado como o caminho moralmente edificante e obrigatório para aqueles que gozavam de saúde e, de outro lado, assistência para os considerados inaptos, isto é, crianças muito pequenas - as maiores trabalhavam -, pessoas idosas e/ou com deficiência: "tensão porque aqueles que têm o dever de trabalhar, mesmo quando não conseguem trabalho, precisam de assistência, mas não tem direito a ela (...). E atração porque a ausência de um deles impele o indivíduo para o outro, mesmo que não possa, não deva, ou não tenha direito" (BOSCHETTI, 2003:47).

Segundo Karl Polanyi (2000) a principal função destas legislações era impedir a mobilidade dos trabalhadores e, desta maneira, manter a organização tradicional da sociedade e do trabalho. Ao longo de todo esse período, uma única legislação diferiu do paradigma de exclusão entre trabalho e assistência: a Speenhamland Act, de 1795, que representou praticamente a última tentativa de resistência no campo das ações assistenciais à implantação da ordenação capitalista de mercado livre. Esta lei estabelecia o desenvolvimento de um sistema de abonos pagos a todos que recebessem abaixo de determinado rendimento - empregados e desempregados -, como complemento aos salários. O valor de referência baseava-se no preço do pão. Isso assegurava uma espécie de renda mínima aos pobres, independente dos seus proventos, o que de certa forma possibilitava aos trabalhadores um espaço de "barganha" na negociação dos salários. O autor observa que esta lei reduziu o ritmo do processo de proletarização imposto pela Revolução Industrial nascente, mas, por outro lado, também contribuiu para reduzir a produtividade, baixar o valor dos salários e aumentar o número de indigentes. Ao final, a forte pressão competitiva do liberalismo conduziu à revogação da Speenhamland Act, em 1834 (século XIX), que foi substituída pela Nova Lei dos Pobres (Poor Law Amendment Act). Esta legislação radicalizou o sentido filantrópico e fragmentário da assistência contida na antiga Poor Law. Também aboliu os direitos assegurados aos trabalhadores e às suas famílias pela Speenhamland, relegando-as às vicissitudes do mercado e do chamado "trabalho livre", aprofundando o processo de pauperização, bem como elevando as tensões e contribuindo para o acirramento das contradições entre capital e trabalho.

Destarte, foi no bojo destas contradições, tensões e metamorfoses que a assistência foi experimentando racionalizações e, assumindo um papel estratégico de controle das classes trabalhadoras, sacramentou seu vínculo com a questão social então engendrada. 


\section{b) Questão social e capitalismo monopolista:}

Logicamente, por uma questão de espaço, objeto e complexidade, não cabe, aqui, tecer uma análise acurada sobre todos os detalhes e acontecimentos que configuraram a emergência da questão social ao final do século XIX. O que nos importa é perceber o delineamento contextual geral, as contradições e os antagonismos que a expansão do capitalismo trouxe às relações econômicas e sociais, sobretudo a partir da transição de sua fase concorrencial para a etapa monopólica. Foi este o momento favorável para a expansão e legitimação do Serviço Social como profissão estratégica (IAMAMOTO, 1995).

O século XIX representa o marco do desenvolvimento e expansão do capitalismo industrial: "Como uma avalanche, o regime capitalista alterou tudo o que estava à sua volta, impondo a tessitura de uma nova rede de relações sociais, de um novo ritmo de vida e de trabalho. Revelou, desde logo, que suas influências não se restringiam apenas às relações comerciais ou ao processo industrial; atingia, isto sim, a sociedade como um todo" (MARTINELLI, 2006:69). Indubitável que estas profundas transformações trouxeram aos países ricos (sobretudo europeus), bem como aos detentores dos meios de produção, uma fase de progresso econômico, tecnológico e financeiro jamais experimentado. Mas, devido ao seu caráter essencialmente excludente, expropriador, contraditório, antagônico e povoado por crises de identidade, o mesmo capitalismo produziu ou agravou as desigualdades, alimentando desemprego, violência, prostituição, trabalho infantil e outras faces da miséria desumana: "A ausência de investimentos em infra-estrutura urbana, o flagrante desprezo pelas condições de vida do trabalhador, em especial no que se refere às áreas de saúde e habitação, produziam uma apreciável deterioração da qualidade de vida operária, que se fazia acompanhar de uma significativa elevação dos níveis de morbidade e de mortalidade da população adulta e infantil. Vivendo uma vida minada pela doença, pela fome, pelas adversidades das condições de trabalho, e habitando em locais insalubres e impróprios à vida humana, a família operária tinha a sua expectativa de vida reduzida, sendo freqüentes os óbitos de adultos, jovens e crianças" (idem: 70).

Não obstante, todas estas situações de miséria convivendo ao lado de pomposos esbanjamentos e abusos da parte da burguesia somados às evidentes manifestações de crises pelo sistema capitalista de cariz concorrencial potencializaram, no seio da classe trabalhadora, uma série de inquietações, contestações e revoltas acerca de suas tristes condições. Percebendo-se afligidos por explorações semelhantes, gradativamente os trabalhadores foram abandonando $o$ isolamento e a alienação que a mercantilização thes impunha. $\mathrm{O}$ fortalecimento dos vínculos de coesão e identidade aconteceu, sobretudo, a 
partir das experiências e lutas das associações e organizações sindicais. Notando as suas condições de maneira qualitativamente diferente da ótica positivista da busca de harmonia e ajustamento que as classes dominantes lhes apresentavam até então para resolver os seus problemas sociais, o operariado passou a exigir dignidade, melhores salários e direitos inerentes às suas atividades. Este processo despertou aquilo que a tradição marxista denomina consciência de classe: as aspirações dos trabalhadores passaram a ter, além do sentido econômico, forte tônus político. O mecanismo social - e não mais somente o patrão individualmente - passou a ser visto como essencialmente explorador, carecendo então de muitas mudanças ou mesmo de superação: "Assim, se através do primeiro movimento o trabalhador se uniu em torno de interesses comuns e constituiu uma classe - o proletariado - o segundo movimento levou à produção da classe política: a 'classe para si' (...), aquela que supera a fissura entre a luta econômica e a política, que ultrapassa as questões internas, específicas, que assume conscientemente seu sentido histórico de classe, lutando politicamente por seus ideais" (idem, p.73). Ao se encerrar o século XIX, a questão social estava então colocada em cena. As elites já se sentiam ameaçadas pelo crescimento político dos movimentos, associações e sindicatos dos trabalhadores, sobretudo por conta da ligação destes canais às combativas e revolucionárias teses socialistas que se espalhavam pelo mundo inteiro (PALMA, 1993).

Por outro lado, conforme afirmam José Paulo Netto e outros autores - como Marilda Vilela lamamoto (1995) e Vicente de Paula Faleiros (2000), por exemplo -, a emergência do Serviço Social como profissão socialmente legitimada e enquanto fecunda estratégia técnica racionalizada e mesmo ideológica de resposta da parte do Estado e do empresariado às demandas suscitadas pela questão social não deve ser concebida desvinculada do contexto de transição interna do capitalismo concorrencial para a fase monopólica, sob o risco de se perder "a particularidade histórico-social do Serviço Social terminando-se por distingui-lo apenas institucional e formalmente da tradição das suas protoformas - quanto se obscurece o lastro efetivo que o legitima como atividade profissional como tal - respaldada por sua funcionalidade no espectro da divisão social (e técnica) do trabalho na sociedade burguesa consolidada e madura" (NETTO, 1992:14).

Nesta etapa de transição capitalista concorrencial para a fase monopólica e de avanço imperialista (quartel final do século XIX), momento significativo para o Serviço Social, cabe ressaltar que: i) sem alterar a essência capitalista, a fase monopólica visou à urgência de viabilização do objetivo primário: acréscimo dos lucros. A diferença é que a metodologia eleita para a consecução de tal meta foi a do controle dos mercados. Isso foi 
feito através de simples 'acordos de cavalheiros' ou até pela fusão de grandes empresas, passando por modalidades e caminhos como cartel, pool e truste, o que alterou também a atuação do sistema bancário e creditício; ii) as implicações econômicas e sociais destas re-configurações na dinâmica econômica capitalista foram amplas e profundas: preços das mercadorias e serviços cresceram progressivamente por conta do monopólio dos grandes grupos; setores monopolizados obtiveram grandes taxas de lucros, promovendo competição doentia (a dita 'livre concorrência'), sucateamento e até falência dos demais setores e empresas que não aderiram ou resistiram aos seus pressupostos; intensificou-se o subconsumo devido à elevação dos custos de vida; cresceu vertiginosamente a tendência de substituição do trabalho humano pelos aparatos tecnológicos, gerando aumento do exército industrial de reserva; a supercapitalização dos grupos monopolistas induziu à uma ociosa especulação financeira e burocratização da vida social; iii) o Estado passou a desempenhar múltiplas funções que visaram legitimar e garantir a vigência dos lucros monopolistas, numa função de comitê executivo: "Mais exatamente, no capitalismo monopolista, as funções políticas do Estado imbricam-se organicamente com as suas funções econômicas" (NETTO, 1992:21). E, além do financiamento para a reprodução do capital, o Estado ganha novo papel ${ }^{34}$, respondendo pela conservação física da força de trabalho abatida pela exploração: "O Estado - como instância da política econômica do monopólio - é obrigado não só a assegurar continuamente a reprodução e a manutenção da força de trabalho, ocupada e excedente, mas é compelido (e o faz mediante os sistemas de previdência e segurança social, principalmente) a regular a sua pertinência a níveis determinados de consumo e a sua disponibilidade para a ocupação sazonal, bem como a instrumentalizar mecanismos gerais que garantam a sua mobilização e alocação em função das necessidades e projetos do monopólio" (idem: 23).

No caso do Brasil: "o aprofundamento do padrão monopolista da organização econômica implicou uma reordenação da dominação burguesa e, conseqüentemente, das relações desta classe com as demais, com o Estado, com as grandes corporações e as nações centrais, com as quais os laços foram estreitados (...). Explicita-se uma nova correlação de forças, mais favorável às necessidades decorrentes do processo de aprofundamento capitalista nacional e internacional (...). A conseqüência da implantação (...) é a queda do padrão de vida dos assalariados, além da desarticulação dos organismos político-reivindicatórios da classe trabalhadora" (IAMAMOTO, 1995:80-82).

\footnotetext{
34 "No capitalismo concorrencial, a intervenção estatal sobre as seqüelas da exploração da força de trabalho respondia básica e coercitivamente às lutas das massas exploradas ou à necessidade de preservar o conjunto de relações pertinentes à propriedade privada burguesa como um todo ou à combinação desses vetores (...). No capitalismo dos monopólios a questão social se internaliza na ordem econômico-política” (NETTO, 1992: 22 e 25).
} 
Mas, qual é a relação entre o capitalismo monopolista, a questão social e o Serviço Social? Em primeiro lugar, caberia afirmar que "o capitalismo monopolista, pelas suas dinâmicas e contradições, cria condições tais que o Estado por ele capturado, ao buscar legitimação política através do jogo democrático, é permeável a demandas das classes subalternas, que podem fazer incidir nele seus interesses e suas reivindicações imediatas" (NETTO, 1992:25). Esses espaços decorrentes das seqüelas e manifestações da questão social passam a tornarem-se potenciais objetos de "intervenção contínua e sistemática por parte do Estado" (idem: 25). E, ato contínuo, o caminho adequado para a execução destas intervenções passou a ser a implementação de políticas sociais (FALEIROS, 2000). ${ }^{35}$

Esse quadro representará, para o Serviço Social, a transformação do seu sentido e significado social, bem como o momento legitimador para a sua institucionalização, tornando-se assim categoria assalariada, alargando-se sua base social de recrutamento, especialmente entre os setores médios ou da pequena burguesia, que buscam nele uma profissão remunerada. Saindo do âmbito das medidas de caridade e da filantropia de associações, o Serviço Social seculariza-se e "deixa assim de ser um mecanismo de distribuição de caridade privada das classes dominantes para se transformar em uma das engrenagens de execução das políticas sociais do Estado e setores empresariais, que se tornam seus maiores empregadores" (IAMAMOTO, 1995:94). Destarte, as ações outrora utilizadas já não poderiam dar conta das complexas manifestações da questão social. $E$ justamente neste ponto está o vínculo contraditório entre capitalismo monopolista, questão social e Serviço Social: "o pano de fundo do processo de institucionalização do Serviço Social, como profissão na sociedade, é a questão social, isto é, o processo de formação e desenvolvimento da classe operária e seu ingresso no cenário político, exigindo, a partir de suas lutas, o seu reconhecimento como classe por parte do Estado e do empresariado. $O$ Estado passa a intervir nas relações entre o empresariado e a classe operária através de legislação social e trabalhista, da prestação de serviços sociais previstos nas políticas sociais. Estes se tornam meios de enfrentamento do processo de pauperização das classes trabalhadoras e luta na defesa de seus interesses classistas e de suas necessidades imediatas de sobrevivência" (idem: 95). Do ponto de vista do capital, tais políticas assumem caráter ideológico de controle e manipulação, além de representar economia de recursos que seriam despendidos com a elevação dos salários.

\footnotetext{
35 “Não há dúvidas de que as políticas sociais decorrem fundamentalmente da capacidade de mobilização e organização da classe operária e do conjunto dos trabalhadores, a que o Estado, por vezes, responde com antecipações estratégicas. Entretanto, a dinâmica das políticas sociais está longe de esgotar-se numa tensão bipolar. Elas são resultantes extremamente complexas de um complicado jogo em que protagonistas e demandas estão atravessadas por contradições, confrontos e conflitos” (NETTO, 1992:29).
} 


\section{2 - Neotomismo e positivismo na profissão}

A emergência do Serviço Social como profissão está intrinsecamente vinculada a um marco específico: as possibilidades ocupacionais abertas no mercado de trabalho demandadas a partir do contexto econômico e histórico-social do capitalismo de cariz monopolista. Afirmar isto significa, em primeiro lugar, abandonar os pressupostos equivocados das teses mecanicistas, lineares e continuístas, que percebem o processo de profissionalização e institucionalização do Serviço Social como resultado cumulativo da especialização teórico-metodológica dos agentes e da organização mais criteriosa das formas assistenciais filantrópicas e caritativas já desenvolvidas, aliás, desde os primórdios da humanidade. Ainda que sejam inegáveis as influências dos modelos e concepções das ações assistenciais desenvolvidas pela Igreja Católica na organização inicial da profissão, há uma profunda e decisiva diferença entre perceber que a profissão valeu-se de modelos e discursos destas práticas e entre concebê-la como simples continuidade destas ações, até porque ambas hoje subsistem de maneira diferenciada. Numa palavra: o fato da institucionalização e profissionalização do Serviço Social ter sido inicialmente estimulada e mesmo fundamentada por orientações de instituições religiosas e por associações filantrópicas não deve encobrir de forma acrítica e a-histórica o pano de fundo capitalista de perfil monopolista que realmente engendrou o movimento de ascensão da profissão. Foi justamente a ruptura - e não a continuidade ou especialização - com estas práticas caritativas e filantrópicas (mas não em termos de discursos e retóricas) que potencializou a profissionalização do Serviço Social, sobretudo para suprir a necessidade de agentes técnicos executores das políticas sociais implementadas pelo Estado para contemplar exigências de ordem econômica e social postas pelo capitalismo monopolista. Ou, numa palavra, o capitalismo monopolista fundou a profissionalização do Serviço Social,

inserindo-o (também os assistentes sociais) na divisão social e técnica do trabalho: "a profissionalização do Serviço Social não se relaciona decisivamente à 'evolução da ajuda', à 'racionalização da filantropia' nem à 'organização da caridade'; vincula-se à dinâmica da ordem monopólica. Só então que a atividade dos agentes do Serviço Social pode receber, pública e socialmente, um caráter profissional" (Netto, 1992:70).

De fato, as idéias de continuidade têm ponderações interessantes, mas não se constituem, conforme bem analisa José Paulo Netto, como as "chaves" que possibilitam entender a profissionalização do Serviço Social. Esta aparente relação causal: "se explica porque um novo agente profissional no marco da reflexão sobre a sociedade ou da 
intervenção sobre os processos sociais, não se cria a partir do nada. A constituição de tal agente começa por refuncionalizar referências e práticas preexistentes, assim como as formas institucionais e organizacionais às quais elas se vinculam" (idem: 67). Ademais: "quando se conformam as referências e práticas próprias do novo agente, estas nem sempre implicam a supressão quer do background ideal, quer dos suportes institucionalorganizativos anteriores, podendo conservá-los por largo tempo" (idem: 67).

Desfeita e esclarecida tal diferença sobre a origem da profissão, cabe analisar duas fortes influências e/ou referências conservadoras que povoaram - e ainda povoam sentidos, projetos e ações do Serviço Social nos seus primeiros passos, repercutindo mesmo como grave motivação para a escolha da profissão da parte de alguns. Tratam-se das doutrinas e aportes filosóficos emanados do pensamento neotomista e do positivismo.

a) O neotomismo

O neotomismo é um movimento de busca de retorno à filosofia tomista da Idade Média, resgatada à luz de tendências intelectuais modernas e retomada especialmente a partir de 1879, por influência da encíclica Rerum Novarum, do Papa Leão XIII. Trata-se, de maneira mais ampla, da corrente filosófica que procura resgatar o Tomismo, a filosofia do eminente pensador italiano Santo Tomás de Aquino, com o objetivo de lançar argumentos e reflexões que possam ajudar a resolver problemas contemporâneos. Evidentemente, o neotomismo não é o mesmo que a obra de Santo Tomás, do mesmo modo que o marxismo nem sempre representa o pensamento de Marx. Ademais, o uso político e instrumental feito de sua obra (muitas vezes até por setores da lgreja) não deve ser confundida com as intenções do escritor. Indubitavelmente, é uma escola filosófica e teológica bastante profunda, complexa e ampla, donde segue que o foco em que será aqui analisada será tão somente na perspectiva da sua influência no Serviço Social.

Para o neotomismo, a filosofia moderna e mecanicista, a partir de Descartes, apresenta alguns erros e equívocos responsáveis pela crise e fragmentação do mundo moderno. Há um forte apelo social na visão neotomista, que considera inaceitável privilegiar interesses de ideologias como o neoliberalismo ou o comunismo, por exemplo, ou ainda de instituições como empresas e o governo, em detrimento do direito do ser humano a uma vida digna e a tudo que ela acarreta: a liberdade, a educação, a saúde, o emprego, a habitação. Numa palavra: a originalidade do neotomismo está em sinalizar que o ponto de vista de Deus e o ponto de vista do homem podem conjugar-se para dar origem a uma visão de mundo coerente e harmoniosa (LIBÂNIO E MURAD, 2003). 
Historicamente, a influência da concepção de homem veiculada pela doutrina da Igreja Católica nas primeiras formulações teóricas do Serviço Social foi muito grande, notadamente no contexto latino-americano, especialmente no Brasil (IAMAMOTO, 1996). Esta concepção inspira um projeto societário e a idealização de uma prática profissional que pretendia ser confluência de doutrina e técnica, a serviço da construção do bem comum. E, neste contexto, uma das fontes teóricas a partir das quais se constrói a atuação profissional, ainda incipiente, é a análise de aspectos constitutivos da pessoa humana na perspectiva neotomista. De forma geral, as publicações dos primeiros assistentes sociais apontam para uma constante preocupação com um projeto societário que viesse a amenizar os efeitos nefastos do capitalismo, com a formação profissional, com a definição do objetivo e da prática do Serviço Social. Estas preocupações centralizavam-se no necessário respeito à pessoa humana e referiam-se à concepção de homem postulada pela perspectiva da filosofia neotomista preconizada pela Igreja naquele momento histórico. Todavia, a concepção de homem das primeiras assistentes sociais situava-se mais no horizonte metafísico ${ }^{36}$. Entendiam que o homem, como pessoa humana, era portador de um valor soberano a qualquer outro valor temporal e tinha sua existência regulada por duas instâncias: uma temporal (material) e outra determinante sobre a primeira, atemporal (espiritual), entendida como parâmetro último para a sua realização enquanto pessoa que caminha para a vida eterna (GUEDES, 2000).

A partir dessa concepção, as assistentes sociais vinculavam o exercício profissional a alguns princípios não submetidos ao movimento histórico. Entendiam, desta forma, que a formação profissional deveria ser orientada pela doutrina católica que era, no entender da categoria, aquela mais bem constituída por princípios verdadeiros, porque peremptórios, válidos por isso para todos em todos os tempos (MARTINELLI, 2006). O entendimento da Doutrina Social da Igreja naquele período - oficialmente explicitada nas encíclicas Rerum Novarum (1881) e Quadragesimo Ano (1921) -, propunha o necessário envolvimento dos cristãos com os problemas sociais advindos da questão social. Nessas propostas, ao referir-se, sobretudo, à exploração dos operários, a doutrina explicitava a concepção de homem de inspiração neotomista ${ }^{37}$. Os primeiros assistentes sociais tinham filiação teórica neotomista. Entendiam assim que o homem apresentava-se à razão como unitariamente composto de corpo e alma. Todavia, por se tratar de ser social incompleto, deveria buscar na vida caridosa e fraterna com os outros a construção de seu fim último.

\footnotetext{
36 “À concepção religiosa de mundo correspondia uma concepção religiosa de prática” (MARTINELLI, 2006:120).

${ }^{37}$ Vide, por exemplo, a encíclica Aeterni Patris, de Leão XIII, que fala de uma nova escolástica.
} 
Jacques Maritain, uma das maiores expressões inspiradoras da filosofia neotomista no Brasil, considera o homem como pessoa dotada de corpo e alma, entendendo que a sociedade é uma instância da qual este homem não pode prescindir em sua existência corpórea (MARCONDES, 2006). A sociedade, além de garantir a sobrevivência física do homem, permite-lhe atender à solicitude da alma (o fim atemporal). A partir desse pressuposto neotomista, os assistentes sociais idealizavam um projeto societário que contemplasse as duas dimensões do homem: o corpo e a alma. Neste sentido, a sociedade era entendida como meio posto ao homem para colimar livre e plenamente sua destinação. A sociedade é instância na qual o homem pode completar-se e realizar-se como pessoa humana. A partir dessa idealização de projeto societário, os primeiros assistentes sociais recusavam, conforme sugeriam as orientações da Igreja, tanto o comunismo quanto o liberalismo. Interpretavam o comunismo como uma teoria social refutável, postulante de um projeto societário erigido por uma compreensão exageradamente materialista. Refutavam-no, ainda, porque o entendiam como doutrina totalitária e avessa à religião, portanto portadora de princípios incongruentes com o conceito de pessoa humana. E, também por esta mesma via - da incompatibilidade com a natureza humana -, que estes assistentes sociais interpretavam os princípios do liberalismo como uma doutrina mui individualista. Refutando liberalismo e comunismo, o Serviço Social, deveria apoiar-se em uma terceira via: um caminho que representasse um meio termo entre o individualismo (doutrina liberal) e o coletivismo (perspectiva socialista), cujo parâmetro fosse o exercício vital inerente à pessoa humana: o aperfeiçoamento com vistas ao fim supratemporal. Nesta terceira via, o modelo societário refere-se à reconciliação entre classes sociais organizadas buscando o bem comum (CASTRO, 2000).

Um outro ponto fundamental ao Serviço Social de inspiração neotomista é a insistência quanto ao caráter técnico aliado à sólida formação moral, como um requisito necessário e indispensável aos profissionais. Nesse sentido, as escolas de Serviço Social deveriam, segundo Ferreira: "desenvolver a personalidade dos alunos, garantir sua formação profissional, dando-lhes (sic) o conhecimento dos problemas sociais e a técnica do trabalho a ser realizada (...). Para atingir sua finalidade o programa de ensino deve ser vivificado por uma sólida doutrina e, por outro lado, corresponder às necessidades do Serviço Social em geral e às necessidades e possibilidades particulares da sociedade que ela quer servir" (Ferreira, 1941:29). Doutrina e técnicas são, pois, neste contexto, parâmetros básicos para a atuação do assistente social. A doutrina oficial da lgreja Católica (1930/1940) sempre considerou o homem como pessoa sobre a qual é possível 
começar a reconstituir os valores morais da sociedade, que deve caminhar para o bem comum. O cumprimento deste pressuposto deve ser assegurado, no caso dos profissionais, por sólida formação moral. O preparo técnico não basta ao assistente social; é necessário que ele seja aliado a uma sólida formação moral porque, quase sempre, terá o assistente social de pôr à prova seus princípios morais, quer aconselhando, quer adotando uma atitude frente aos problemas de ordem moral daqueles que o procuram.

Ainda na perspectiva da formação moral e técnica, os assistentes sociais destacam a importância do estágio em que ocorre a "adaptabilidade" dos futuros assistentes sociais às circunstâncias sociais e situações que lhes são estranhas e que pode chocá-los ou mesmo escandalizá-los. Contudo, a formação moral e o aperfeiçoamento, segundo Ferreira: "devem ser constantes entre os assistentes sociais, para que sua técnica não se degenere em tecnicismo, sua ciência em cientificismo e a profissão em profissionalismo. 0 assistente social não é apenas um profissional, mas alguém que se preocupa, prioritariamente, em fazer o bem e contribuir para a solução mais perfeita dos problemas sociais" (FERREIRA, 1941:27). Uma das tantas outras premissas sobre as quais se erige o aperfeiçoamento profissional deve ser o respeito à pessoa humana, isto, é, aos nossos irmãos ou semelhantes: "Sem este pressuposto, sem esta marca profunda de humanidade, o Serviço Social seria desastroso" (MANCINI, 1939:3). Esta é a base segura que, como uma: "bússola que tanto mais é solicitada, quanto pior o tempo e desorientado o navegante, socorre aos que estão imersos no labor; é preciso que estes tenham uma noção exata do porto a atingir, dos caminhos certos ou nocivos que possa encontrar" (FERREIRA, 1941:28). Deste modo, na prática do assistente social, tanto a inteligência como a vontade deve ser colocada a serviço da pessoa humana, que caminha para Deus.

Movendo-se, ainda, sob a perspectiva do neotomismo, na qual a pessoa humana dotada de inteligência pode orientar-se e orientar os outros para o bem comum, os assistentes sociais nesse período enfatizavam sobremaneira o aspecto vocacional contido na atuação profissional. Mais que uma escolha profissional, o Serviço Social em sua gênese se coloca como um compromisso de vida com o projeto de uma sociedade erigida sobre a idealidade cristã, aos moldes daquela postulada por Maritain. Sob tais propósitos, delineiam-se os atributos que deve ter um assistente social: responsabilidade, sacrifício, perseverança, jovialidade, desinteresse material, capacidade de sentir, capacidade de adequar-se ao ritmo acidentado dos necessitados e, também, maturidade para não se assustar com a realidade a ser conhecida: "As qualidades pessoais, a vocação, a disposição para servir continuavam presentes como elementos essenciais, aos quais era 
preciso acrescentar o preparo técnico-científico para o adequado exercício da prática social" (MARTINELLI, 2006:121). Os primeiros assistentes sociais idealizavam a construção de um projeto societário, através da reeducação de valores morais e obediência aos princípios cristãos, mas argumentavam que este projeto só se viabilizaria se fossem asseguradas as mínimas condições de bem-estar social. $\mathrm{Na}$ defesa da viabilização deste projeto, os assistentes sociais restringiam a atuação profissional mais à esfera privada, como se os valores morais fossem construídos apenas a partir de vontades individuais e as precariedades materiais de existências fossem amenizadas com esforços individuais. Contudo, simultaneamente, tais assistentes sociais criticavam a ênfase no indivíduo posta pelo liberalismo, colocando-os em um dilema (GUEDES, 2000).

Em suma: os assistentes sociais, ao seguirem, sem reservas, às orientações das encíclicas papais, partilhavam das críticas erigidas pela Igreja Católica ao liberalismo, ao comunismo e também ao socialismo. Situavam-se na perspectiva de uma terceira via: o humanismo cristão que defende a construção de valores cuja premissa básica é o respeito à dignidade da pessoa humana. Esta premissa, na descrição da compreensão da prática dos primeiros assistentes sociais os coloca diante de uma possível dicotomia entre teoria e prática, como se naquele momento (1939/1940), ao menos nos pressupostos teóricos dos assistentes sociais, o homem fosse compreendido como uma pessoa humana e na atuação profissional fosse compreendido como um indivíduo que precisa de ajuda para sair do ambiente decaído, no qual a condição de vida operária o colocava. Neste contexto, a recuperação de quadros sociais degenerados, segundo esses assistentes sociais se dá, sobretudo, a partir da atuação profissional junto a indivíduos e famílias, mas a perspectiva teórica que anima essa prática profissional é a realização da pessoa humana, que se dá de forma definitiva numa esfera transcendente à materialidade das condições de vida. Contudo, o agravamento da questão social no contexto do capitalismo monopolista, somado à influência da secularização - afastamento da religião - da sociedade, a institucionalização profissional e a busca e o contato constante das assistentes sociais com métodos hauridos das ciências sociais fez, em alguns anos, que a influência do neotomismo fosse experimentando o ocaso, cedendo grande parte de seu espaço para visões positivistas e funcionalistas da sociedade. E, ainda que a lgreja mantivesse (como mantém até hoje) as suas ações sociais, o Serviço Social já ia mostrando-se, na medida em que se abriam espaços profissionais nas distintas frentes estatais e privadas - por demanda do próprio mercado -, cada vez mais desvinculado do modelo franco-belga do "servir", embora os seus agentes ainda fossem majoritariamente pessoas mui religiosas. 


\section{b) Positivismo e funcionalismo}

O positivismo é uma corrente filosófica cujo iniciador principal foi Augusto Comte (1798-1857). Surgiu como desenvolvimento filosófico do lluminismo, a que se associou à afirmação social das ciências experimentais. Propõe à existência humana valores completamente humanos, afastando radicalmente a teologia ou a metafísica. Além de ser uma reação ao idealismo kantiano e ao neotomismo, o positivismo foi também fruto do grande progresso das Ciências Naturais no século XIX, particularmente das biológicas, físicas e fisiológicas. Em termos gerais, buscou transpor para o âmbito das Ciências Humanas os métodos e procedimentos analíticos das Ciências Naturais, visando assim lograr mesmo êxito (MARCONDES, 2006). Foi impulsionado pelo avanço da tecnologia e, concomitantemente, pelas manifestações da questão social, funcionando como uma base filosófica justificadora e adequada à naturalização dos padrões de produção e consumo.

De maneira bastante complementar e contemporânea às idéias positivistas, o funcionalismo (ligado às teses estruturalistas) também representou uma tendência à naturalização e justificativa aos padrões sociais e econômicos vigentes. De modo geral, é uma doutrina que compara a sociedade a um organismo, onde as diferentes parcelas (níveis) da mesma exercem um determinado papel necessário para gerar o bem-estar do conjunto. Segundo as teses de Talcott Parsons (o intelectual do fordismo), a sociedade e a respectiva cultura formam um sistema integrado de funções. O Dicionário de Ciências Sociais (1987) define o funcionalismo como: "a perspectiva utilizada para analisar a sociedade e seus componentes característicos enfocando a mútua integração e interconexão deles. O funcionalismo analisa o caminho que o processo social e os arranjos institucionais contribuem para a efetiva manutenção da estabilidade da sociedade. A perspectiva fundamental é oposta às maiores (sic) mudanças sociais" (p.96).

De forma geral, estas duas "escolas" filosóficas e sociológicas tenderam a investir na análise das desigualdades e das manifestações fragmentadas e isoladas da questão social a partir de instâncias psicológicas de cunho individual e privado, donde segue que as 'anomalias' (diria Durkheim), os conflitos e os desvios sociais deveriam ser 'tratados' na perspectiva da (re) integração dos indivíduos-problema ao corpo social (lamamoto, 1995). Esquema básico das representações positivistas e funcionalistas da sociedade:

\begin{tabular}{|l|l}
\hline Adaptação (base material): & Objetivos a alcançar (sistema político):
\end{tabular} Integração funcional dos indivíduos Manutenção pela reprodução dos modelos ao corpo ou sistema social culturais (na família / pela elite do poder) 
Conforme visto, as alterações e implicações advindas do capitalismo monopolista foram amplas e profundas em todos os níveis sociais. E, neste contexto, o positivismo constituiu-se como forte ideologia a serviço dos interesses das classes dominantes, de modo a ser tido como "auto-expressão ideal do ser social burguês" (NETTO, 1992:39). Isto porque, ao converter as manifestações da questão social em meras disfunções de ordem individual (moral e psicológica), tal corrente operou um verdadeiro controle social que, pelo seu modus operandi, descaracterizava e esvaziava o sentido de contestação crítica econômica e política que se fazia da questão social, algo conveniente ao capital.

No caso do Serviço Social (e das outras ciências sociais) ${ }^{38}$ de cariz conservador, os postulados positivistas e funcionalistas tiveram intensa influência e ampla aceitação por toda a América Latina e, notadamente, no Brasil, sobretudo a partir da importação do modelo desenvolvimentista norte-americano. Não é exagero algum afirmar que os ecos positivistas e funcionalistas se fazem presentes até mesmo nos dias atuais, começando do simples cotidiano profissional e alcançando até a esfera das políticas sociais federais. Uma das construções simbólicas (e míticas) mais significativas para este estudo refere-se à idéia de profissionais neutros e moralistas, marcados pela conduta profissional objetivista, apolítica e reintegradora, com vistas ao estabelecimento da ordem e harmonia social. A tese positivista de neutralidade era "sustentada por essa concepção em se partia do conceito preestabelecido de normalidade, de equilíbrio da sociedade, que levou os profissionais a considerarem que a promoção do homem consistia em se tentar corrigir as distorções sociais, levando o homem a um ajustamento ao meio" (SILVA, 1983: 53).

Também a tendência recorrente das políticas sociais (do Estado e do empresariado) no capitalismo monopolista foi a de fragmentação e parcialidade, procurando-se ocultar as contradições entre capital e trabalho. Através de ações nas diferentes conseqüências da mesma questão social ${ }^{39}$, constituiu-se a idéia de que estes recortes seriam problemáticas isoladas e particulares (disfuncionalidades), que deveriam ser tratadas como desvios individuais da lógica natural e da ordem social: "Tradicionalmente, prevaleceu o princípio da causalidade individual, que atribuía responsabilidade pessoal àqueles que sofriam os problemas sociais, desligando-se - intencionalmente - a relação existente entre $O$ funcionamento global da sociedade e a presença dos chamados 'males sociais'. A partir desta mesma ótica, assumia-se a desigualdade social como uma espécie de fato natural e, portanto, sequer se cogitava do questionamento do sistema" (ALAYÓN, 1995:31).

\footnotetext{
38 "A influência exercida na área da sociologia pelo positivismo foi responsável pela informação científica do serviço social, cujas experiências esparsas não focalizavam a problemática do homem numa visão globalizada” (SILVA, 1983:52).

${ }^{39}$ Por exemplo: a questão do desemprego, a questão da fome, a questão habitacional, a questão rural, etc...
} 
A intervenção do Serviço Social com os métodos de caso e de grupo ${ }^{40}$ é um exemplo típico da maneira positivista e funcionalista de concepção e intervenção profissional, embora também guarde ainda alguns resquícios neotomistas. Os escritos da pioneira assistente social norte-americana Mary Richmond atestam, para além do meritório esforço de sistematização e organização da ação profissional, o forte sentido de 'reintegração' ou busca de 'adaptação' dos indivíduos e grupos (meios) problemáticos à sociedade 'normal'.

Todavia, o grande destaque que emerge a partir dos postulados positivistas e funcionalistas foi, ao menos para o contexto latino-americano, a ascensão da ideologia do Desenvolvimento de Comunidade $^{41}$, tendo em vista o modelo do pan-americanismo desenvolvimentista, que foi um fruto visível da hegemonia norte-americana no continente e do suporte de organismos internacionais (ONU), com vistas à expansão capitalista, bloqueio da expansão comunista e controle dos movimentos sociais ${ }^{42}$ : "Foi no âmbito da influência norte-americana que importamos, progressivamente, os métodos de Serviço Social de Caso, Serviço Social de Grupo, Organização de Comunidade e, posteriormente, Desenvolvimento de Comunidade (...). Absorvendo a ideologia desenvolvimentista, o Serviço Social se impunha duas tarefas fundamentais: viabilizar a participação do povo no projeto desenvolvimentista do governo e neutralizar as tensões resultantes das contradições da política desenvolvimentista" (SILVA E SILVA, 1984:41). Isso se fez de forma expansiva, quando a profissão: "Estabelece maior vínculo com órgãos estatais e prioriza seu engajamento em programas de desenvolvimento de comunidade, ampliandose suas funções com a inclusão da coordenação e do planejamento" (idem: 42).

$\mathrm{Na}$ busca de racionalização, a prática profissional avançou em termos de incorporação de métodos, logística e instrumentos de trabalho, passando a desenvolver atividades de plantão, triagem, prática burocrática, acompanhamentos, aconselhamentos, distribuição de auxílios e socialização, através dos grupos e engajamentos em equipes multiprofissionais, sobretudo nos trabalhos de comunidade. Tudo isso aperfeiçoou e expandiu a especialização profissional técnica, mas continha a tendência de eximir-se a profissão de compromissos políticos. Nesse mesmo período, multiplicaram-se as escolas de Serviço Social em todo o continente latino-americano e, especificamente, no Brasil ${ }^{43}$.

\footnotetext{
${ }^{40}$ Obviamente, tais metodologias não nasceram ao mesmo tempo. O trabalho com grupos veio somente na década de 30.

41 "A conceptualização sobre organização de comunidade revela uma perspectiva profundamente funcionalista no trato da questão social e o seu desenvolvimento, quase exclusivamente, está centrado nas peculiaridades da sociedade norte-americana. A identificação das necessidades e a alocação de recursos reduzem a questão social a problemas técnicos, construindo (...) uma fórmula central que contempla múltiplas variantes de intervenção profissional” (CASTRO, 2000:142).

${ }^{42}$ Dessa parceria emergiu a chamada "Aliança para o Progresso" no governo de John Kennedy. Caracteriza-se como uma série de incentivos, empréstimos, doações e “ajudas” de capital para os programas de desenvolvimento social.

${ }^{43}$ Nossa primeira escola foi criada em 1936, no seio da Ação Católica: Escola Paulista de Serviço Social de São Paulo.
} 
Porém, análise mais crítica acerca da ideologia desenvolvimentista aponta que, para além da euforia inicial das oportunidades de especialização e profissionalização que trouxe ao Serviço Social, o Desenvolvimento de Comunidade representou um eficiente mecanismo de sujeição das organizações populares à tutela oficial, ainda mais quando se converteu em prática e diretriz da ação política de diversos regimes populistas e/ou ditatoriais nos países latino-americanos. Passados alguns anos e tantos acontecimentos históricos significativos, mais ao final da década de 50 , os assistentes sociais já apresentavam, nos diversos congressos e encontros - de forma mais intensa nos espaços e produções acadêmicas - sinais claros de descontentamento e contestação em relação aos rumos da profissão. Nos campos e nas cidades cresciam os movimentos populares. Nas universidades, muitas profissões passavam por revisões críticas de suas posturas teórico-metodológicas. O movimento estudantil também ensaiava coros de mudanças. As políticas desenvolvimentistas não logravam os intentos pretendidos. O mofo dos métodos positivistas e funcionalistas revelava ao Serviço Social, ao final, a nítida ausência de um objeto específico ${ }^{44}$ para a ação e de uma base teórica de conhecimentos que refletisse a realidade das contradições e antagonismos de classes com que os seus profissionais se deparavam no cotidiano. Ademais, o contato com literaturas marxistas e o progressivo esgotamento da panacéia simbólica do assistente social como 'agente de transformação' pois a prática mostrava-Ihes mais como agentes da conservação - abriu, dialeticamente, caminhos para a ruptura profissional com a dita herança conservadora (NETTO, 1992).

\section{3 - Algumas protoformas do Serviço Social no Brasil}

As influências doutrinárias mencionadas, hauridas tanto do pensamento humanistacristão neotomista, do positivismo e do funcionalismo, assim como as metodologias de trabalho do Serviço Social de Caso, de Grupo e posteriormente a ideologia do Desenvolvimento de Comunidade também estiveram presentes no contexto nacional, respeitando, no entanto, as singularidades, cronologias e perfil sóciopolítico diverso em alguns itens em relação aos demais países latino-americanos. Importam mencionar de forma sucinta - pois não é o nosso objeto de estudo - alguns fatos e contextualizações fundamentais ao entendimento das primeiras políticas sociais e instituições assistenciais do país, marcos históricos legitimadores (embora discutíveis) da profissionalização e expansão do Serviço Social em terras tupiniquins (MARTINELLI, 2006).

\footnotetext{
${ }^{44}$ Somente a leitura crítica permite notar o verdadeiro objeto (embora bem geral) do Serviço Social no bojo conservador: "Para o Serviço Social tradicional, o objeto foi o homem, ou melhor, as formas de previsão e controle de comportamento para os quais o fim - adaptação do homem à sua sociedade - justificava os meios” (KISNERMAN, 1980:43).
} 
Aproximando-se à tese do Serviço Social como evolução das práticas da caridade sob a influência das doutrinas neotomistas, lamamoto e Carvalho (1996) afirmam que as origens do Serviço Social no Brasil estão intimamente vinculadas a iniciativas da Igreja: "como parte de sua estratégia de qualificação do laicato, especialmente de sua parcela feminina, vinculada predominantemente aos setores abastados da sociedade, para dinamizar sua missão política de apostolado social junto às classes subalternas (...). Essa origem confessional, articulada aos movimentos de Ação Social e Ação Católica, conforma um tipo de legitimidade à profissão cujas fontes de justificação ideológica encontram-se na doutrina social da Igreja" (IAMAMOTO E CARVALHO, 1996:83). Essa gênese no seio da Igreja não seria impedimento, mais tarde, para o aproveitamento e cooptação dos outrora chamados "agentes da caridade" pelo aparato do Estado e pelo empresariado, embora ainda mantendo nos discursos e na formação das estudantes aquelas orientações mistificadoras da prática profissional como uma missão ou ainda um serviço aos oprimidos.

Até o final da década de 20 e início da década de 30 , a questão social não havia gerado, no caso do Brasil, mudanças significativas em termos da postura "de tratamento" do Estado e do empresariado ${ }^{45}$. Era tão somente uma questão de polícia, isto é, de repressão coercitiva física que visava conter as manifestações e as 'desordens' sociais. Todavia, a grave crise do comércio internacional em 1929 - cujo ícone foi a quebra da bolsa de Nova York - e o movimento revolucionário de $1930^{46}$ aparecem como momentos centrais que culminaram numa reorganização das esferas estatal e econômica em relação tanto ao modelo agro-exportador quanto ao modo de controle da questão social. Esta última, por sua vez, mostrava não poder ser controlada apenas com coerção física. Seria mister, pois, articular assistência e repressão: uma questão de política (NETTO, 1992).

Segundo Faleiros: "Getúlio Vargas, através de sua política trabalhista, buscava, ao mesmo tempo, controlar as greves e os movimentos operários e estabelecer um sistema de seguro social. Falava explicitamente em substituir a luta de classes pela colaboração de classes. Era uma resposta, de cima, aos movimentos de baixo (...). O modelo getulista de proteção social se definia, em comparação com o que se passava no mundo, como fragmentado em categorias, limitado e desigual na implementação dos benefícios, em troca de um controle social das classes trabalhadoras" (FALEIROS, 2000:46). Mais do que

\footnotetext{
${ }^{45}$ Exceto algumas legislações isoladas que beneficiavam algumas classes bem específicas e estratégicas (para a economia) de trabalhadores, como a Lei Eloy Chaves, de 1923, que implementou a previdência social dos ferroviários como resposta às lutas sociais e greves e para manter a economia de exportação do café.

${ }^{46}$ Relacionada aos resultados da grave crise do setor cafeeiro internacional, gerando a formação de uma coalizão heterogênea que levantava a bandeira da diversificação da economia e reforma política, que desembocou no movimento político-militar que pôs fim a Republica Velha (IAMAMOTO, 1995).
} 
avanço, tal estratégia revelou algo típico da experiência republicana brasileira: geralmente quando a elite governante toma decisões importantes em termos de política social, quer sob a pressão das massas, quer como antecipação estratégica, produz, ao mesmo tempo, graves retrocessos políticos (SANTOS, 1987). E esta tese se repetiu tanto nos anos populistas de Getúlio Vargas quanto no desenvolvimentismo de Kubitscheck, no moralismo de Quadros e, sobretudo, na centralização e repressão da ditadura militar.

Desenvolvido a partir da década de 30 (paralelamente ao modelo de seguro social), o modelo assistencial brasileiro fez parte do processo mais geral de construção do Estado moderno, intervencionista, centralizador e legitimador da ordem capitalista monopólica vigente (e bloqueio de influências socialistas e comunistas), após a revolução de 1930. Datam desta época os Institutos de Aposentadoria e Pensões (IAPs), em substituição às Caixas de Aposentadorias e Pensões (CAPs); a Legião Brasileira de Assistência (LBA); o Ministério da Educação e Saúde e o Serviço Especial de Saúde Pública (SESP). A LBA (criada em 1942) havia sido idealizada para atender às famílias de pracinhas envolvidos na guerra. Mas, após 1946, passou a dedicar-se à maternidade e à infância, implantando postos de serviços conforme os interesses, apoios e conveniências. Predominava a prática assistencialista, realizada por obras de caridade (religiosas) e ações de primeiras-damas.

Todo este efervescente contexto nacional e internacional e o avanço da questão social fizeram, logicamente, avançar os espaços e demandas pela profissionalização e institucionalização do Serviço Social. Em 1932, buscando maior legitimação junto à sociedade e notando a necessidade de uma ação social mais efetiva e técnica do laicato feminino que participava de seus grupos a Igreja criou o Centro de Estudos e Ação Social (CEAS), considerado o passo inicial da profissionalização do Serviço Social no país (CASTRO, 2000). A primeira escola de Serviço Social foi criada em 1936, no seio da Ação Católica: Escola Paulista de Serviço Social de São Paulo. Também sobre a inspiração confessional foi organizada (entre 1938 e 1940) a escola superior de Serviço Social do Rio de Janeiro, nos mesmos moldes da escola de São Paulo, mas com maiores variedades e atuações $^{47}$. E, ao longo da década de 40 diversas escolas de Serviço Social foram criadas noutras capitais, todas elas sob os incentivos e auspícios da Igreja, mas, de maneira nova, contavam com o apoio financeiro da recém-criada Legião Brasileira de Assistência (LBA). Mas, embora organizado sob estímulo decisivo da Igreja, isto não significa conceber o Serviço Social brasileiro como especialização da caridade, mas como resposta gestada pelas mudanças advindas do capitalismo monopolista (NETTO, 1992).

\footnotetext{
${ }^{47}$ Outra referência importante é a criação do Conselho Nacional de Serviço Social, em 1938, via decreto-lei.
} 
Em suma: de maneira ampla e histórica, as primeiras políticas sociais brasileiras - e, portanto, as ações e repercussões que estas impostaram no trabalho e na representação social dos assistentes sociais - tiveram como recorrência as marcas ou as "caras" dos governos e dos grupos que ocupavam o poder no momento ou ainda de instituições que mantinham alguma influencia neste, não se constituindo como políticas de cunho estatal e estratégico, fundamentadas no reconhecimento da cidadania e busca de emancipação das pessoas. O padrão de proteção social configurado só veio a sofrer alterações significativas com a Constituição Federal de 1988. Predominaram até então - largamente - o assistencialismo, o paternalismo, as fragmentações, restrições, cooptações e controles sob as entidades representativas da classe trabalhadora. Outro aspecto marcante foi, desde os primórdios, a contraposição entre trabalho e assistência social, destinando esta última somente aos incapazes provisória ou definitivamente para o exercício reconhecido legalmente - ou formalmente - do primeiro (BOSCHETTI, 2003). Sônia Fleury vê nestas contraposições e antagonismos àquilo que denomina relação de cidadania invertida, porquanto: "No modelo assistencial, as ações, de caráter emergencial, são dirigidas aos grupos de pobres mais vulneráveis, inspiram-se em uma perspectiva caritativa e reeducadora, organizam-se com base na associação entre trabalho voluntário e políticas públicas, estruturam-se de forma pulverizada e descontínua, gerando organizações e programas muitas vezes superpostos (...). Não configuram uma relação de direito social, tratando-se de medidas compensatórias que terminam sendo estigmatizantes. Por isso, denomino essa relação como de cidadania invertida, na qual o indivíduo tem que provar que fracassou para ser objeto da proteção social" (FLEURY, 2004:110).

\section{0 - A ruptura teórico-metodológica}

O Serviço Social nasceu e deu os seus "primeiros passos" sob a vigilância atenta das influências européias neotomistas (modelo franco-belga) e, pouco depois, colocadas novas e mais complexas demandas e, visando adquirir procedimentos e status de cientificidade, racionalização e maior institucionalização, a profissão correu ao encontro e abraçou aquilo que havia de mais conservador na Sociologia - também na Psicologia - norte-americana (Escola de Chicago e certas teorias da Psicologia Social), cujas orientações funcionalistas e positivistas impulsionaram e animaram de forma intensa e ampla os diversos metodologismos de estudos de caso, dinâmicas de grupo e desenvolvimento de comunidade por toda a América Latina. Da mesma forma, notamos quão convenientes foram estas concepções para as autoritárias e soberbas pretensões capitalistas 
monopolistas, bem como à expansão do domínio geopolítico norte-americano no continente. $E$, ainda que se buscasse (com boa vontade) realizar intervenções neutras que resolvessem algumas manifestações fragmentárias e isoladas da questão social, a prática e os discursos (de forma geral) dos (das) assistentes sociais ao longo das décadas de 30 , 40 e 50 não conseguiam ultrapassar a lógica circular viciosa e conservadora da tentativa de se humanizar o capitalismo. Após revisão crítica, tornou-se corrente na literatura do Serviço Social contemporâneo chamar tais vinculações de tradicionais, funcionalistas e/ou conservadoras (SILVA, 1983; NETTO, 1992; IAMAMOTO, 1995; MARTINELLI, 2006). No entanto, a ideologia desenvolvimentista padronizada e importada dos Estados Unidos foi se mostrando, paulatinamente, contraditória e repressiva, além de incapaz de surtir efeitos duradouros e eficientes em contextos tão singulares e de problemas sociais tão agudos como dos países latino-americanos. A inoperância "levou alguns profissionais a questionarem a profissão, tendo em vista características diferenciais e específicas dos países latino-americanos no que diz respeito à problemática de natureza estrutural, que envolvem variáveis de ordens econômicas, sociais e políticas" (SILVA, 1983:42). Todo esse estado de mal-estar - que não era exclusividade do Serviço Social - acerca da inadequação e significados da ação profissional perante a realidade subdesenvolvida e injusta dos países latino-americanos, somada à assimilação de teorias críticas forjou, em alguns anos, a tentativa de ruptura ou superação do marco tradicional e conservador em que se apoiava a profissão. Trata-se, numa palavra, do movimento de Reconceituação, fruto da "crise existencial" que se instaurou no Serviço Social a partir da década de 1960.

\section{1 - O movimento de Reconceituação}

Em primeiro lugar, cabe dizer que não existe uma definição conceitual unânime e precisa daquilo que se convencionou chamar por movimento de Reconceituação do Serviço Social ${ }^{48}$. Conforme notaremos, as especificidades de cada país, os sincretismos ideológicos e operacionais que constituíram e direcionavam os rumos das Ciências Sociais e da profissão, assim como os próprios equívocos, indefinições e pluralidade de teses existentes no interior deste movimento não nos permitem chegar a uma idéia final do seu alcance e significado, como se fosse algo monolítico. Por outro lado, é possível perscrutar e notar, para além dos tantos dissensos possíveis, certos pontos comuns e fundamentais que se constituíram como elementos propulsores das mudanças de posturas advindas da Reconceituação, a começar pelo consenso de que a mesma representou uma busca de

\footnotetext{
${ }^{48}$ Até porque todas as correntes teóricas que influenciavam a profissão também passaram por renovações, adaptações e reconceituações. Ao positivismo, por exemplo, sucedeu o neopositivismo.
} 
ruptura teórica com as abordagens tradicionais neotomistas, positivistas e funcionalistas, bem como aos enfoques desenvolvimentistas. Desta maneira, um entendimento possível seria conceber que: "o movimento de reconceituação latino-americano, focalizado em sua globalidade, pode ser considerado como um processo de ruptura teórica, metodológica, prática e ideológica com as concepções que prevaleciam e serviam de embasamento para o desenvolvimento da profissão em moldes tradicionais" (SILVA, 1983:50). Porém, isto não significa dizer que a Reconceituação tenha sido em todos os níveis, objetivos e contextos o abandono das influências e orientações das abordagens citadas. Em muitos casos, o sentido e a intenção foram apenas de readaptações ou reformas, enquanto em outros se assumiam idéias de transformação, libertação ou até mesmo de revolução (PALMA, $1993)^{49}$. O caráter básico deste movimento no Serviço Social foi o de crítica aos modelos tradicionais (caso, grupo e comunidade) importados de países da Europa e da América do Norte (SILVA, 1983). O pressuposto era o de que a profissão deveria revisar suas concepções e intervenções para obter maior consistência interna em termos de conceitos, teoria e prática e, a partir daí, alcançar maior adequação às realidades, demandas e problemáticas específicas dos países latino-americanos. Porém, vale dizer que estas inquietações não eram resultados dos questionamentos suscitados interna e exclusivamente no âmbito do Serviço Social. Outras áreas, como as Ciências Sociais, a Filosofia, a Teologia ${ }^{50}$ e mesmo setores da Economia refletiam acerca de paradigmas que as regiam e, em certos pontos, abandonaram concepções clássicas e abriram-se às influências do pensamento esquerdista. Também o questionamento quanto à situação política repressora dos países latino-americanos se tornou intenso: intelectuais, sindicatos, trabalhadores e estudantes demonstravam repúdio pelas perseguições, censuras, torturas, autoritarismos, centralização excessiva e abusos da parte dos militares (ESTEVÃO, 1999).

De forma mais ampla, a Reconceituação do Serviço Social foi ganhando força na América Latina ao longo da década de 60. No caso do Brasil, tal movimento despertou com certo atraso e com peculiaridades marcantes em comparação aos outros países latino-americanos. Destacaram-se de maneira decisiva os documentos produzidos a partir dos seminários promovidos pelo Centro Brasileiro de Cooperação e Intercâmbio de Serviço Social (CBCISS). São os chamados seminários e documentos de Teorização que, dentre outros assuntos, visaram discutir questões como a cientificidade da profissão, métodos e

\footnotetext{
49 “Convém ressaltar que o movimento de reconceituação do Serviço Social, inicialmente configurado como um movimento unitário, em seu processo de desenvolvimento, assume posturas diversas, delineadas pelos quadros conjunturais dos diversos países do continente, bem como as posições assumidas pelos profissionais no contexto de cada realidade” (SILVA E SILVA, 1984:44).

${ }^{50}$ Exemplo: a Teologia da Libertação - que fez surgir as famosas Comunidades Eclesiais de Base (Cebs) - representou, no âmbito da Igreja, uma emblemática aproximação com categorias e concepções hauridas da tradição marxista.
} 
metodologias, correntes teóricas, objeto, objetivos e posicionamentos políticos da profissão. Foram eles: Araxá (1967); Teresópolis (1970), Sumaré e Alto da Boa Vista ${ }^{51}$.

Buscava-se, pois, um novo fazer profissional, fundamentado por uma nova visão teórica (FALCÃO, 1981). As inquietantes reflexões derivadas desta nova tendência foram, em algum tempo, transformando-se em repúdio àquilo que se percebia como prática profissional atrelada aos interesses dos grupos dominantes. Da mesma forma, vieram ao longo do processo aproximações com a perspectiva dialética marxista. No entender de muitos autores, o objeto da ação profissional deveria se deslocar totalmente dos problemas individuais, grupais e comunitários para a superação dos grandes e fundantes problemas estruturais da sociedade. Outros equívocos e exageros derivados de correntes de negação e de afirmação também estiveram presentes, sobretudo no início do movimento, como, por exemplo, o entendimento da prática institucionalizada - mesmo nas simples ações burocráticas do cotidiano - tanto no governo quanto no setor privado como mera reprodução e comprometimento com os interesses burgueses, visão pouco dialética que gerava crises de consciência aos profissionais que labutavam nestes espaços para buscarem o sustento. Da mesma forma, a aproximação e rápida vinculação com categorias marxianas e marxistas deu-se não raro a partir de distorções e exageros que envergonhariam o próprio Karl Marx e seus seguidores mais sérios. Ademais, não deveriam existir, em contextos tão progressistas e comprometidos com o proletariado, espaços para outras categorias e perspectivas teóricas: "Para se chegar ao Serviço Social era preciso, antes de tudo, falar de luta de classes, de contradição, de tese, antítese e síntese, de formas de ver e ler a realidade, de ideologia; enfim, certa terminologia marxista incorporou-se ao Serviço Social" (ESTEVÃO, 1999:39). Uma das conseqüências mais representativas dos equívocos e reducionismos oriundos da Reconceituação foi vista ao final já nos anos 80, quando correntes ligadas ao Celats - Centro Latinoamericano de Trabajo Social - lançaram a proposta do "Serviço Social Alternativo", muito criticado por sua visão simplista, messiânica, partidarista e a-histórica da profissão (IAMAMOTO, 1995).

Por outro lado, uma importante contribuição e avanço que a Reconceituação trouxe para o Serviço Social foi o reconhecimento e valorização da dimensão política de sua prática, negando a neutralidade outrora tida como virtude. Percebe-se também que ela determinou um salto qualitativo acerca da compreensão crítica e mais global da realidade.

51 Para o contexto e objetivo deste trabalho, creio que mais importante do que esmiuçar os conteúdos destes encontros e documentos é notá-los como importantes marcos de ruptura ou adaptação da profissão a novas demandas e cenários geopolíticos, econômicos, ideológicos e técnico-operativos, o que certamente influiu na representação social da profissão. 


\section{2 - As novas influências: fenomenologia e marxismo}

Além dos questionamentos específicos quanto à necessária busca de renovação dos aspectos operacionais, a Reconceituação abriu espaços também às influências de novas teorias, que se somaram ao repertório praticado desde a origem da profissão até aquele período ${ }^{52}$. Buscavam-se, pois, novos referenciais teóricos que estivessem ligados à legitimação e embasamento científico da identidade assumida pela profissão com as lutas dos trabalhadores e à necessidade de se estabelecer novos vínculos dos assistentes sociais na América Latina ${ }^{53}$, rompendo assim com um passado ligado ao assistencialismo e à integração/adaptação social (ALAYÓN, 1995). Neste sentido, duas novas influências e/ou vertentes teórico-metodológicas destacavam-se no cenário das Ciências Humanas da época: a fenomenologia e o marxismo ${ }^{54}$. Aprouve por isso ao Serviço Social buscar em categorias e literaturas destas teorias elementos que coadunassem com os sentidos, objetivos e diretrizes que se pretendiam transmitir à profissão. Logicamente, nem sempre estas aproximações foram realizadas de modo diligente, profundo e com o discernimento necessário, resultando daí alguns imediatismos superficiais, leituras, interpretações e transposições rasteiras e desafinadas com o sentido real contido nas fontes teóricas. Examinaremos de forma mais ampla, a seguir, questões e motivações que aproximaram o Serviço Social da fenomenologia, do pensamento marxiano e da tradição marxista.

\section{a) Fenomenologia:}

A fenomenologia é o movimento filosófico inaugurado por Husserl e desenvolvido, sobretudo, na França e Alemanha por seus seguidores, constituindo uma das principais correntes do pensamento do século XX. O termo "fenomenologia" foi inicialmente utilizado por Johann Lambert para caracterizar a 'ciência das aparências' e empregado posteriormente por Hegel em sua 'ciência da experiência da consciência', sendo esta última tradição aquela que Husserl inspirou-se em sua obra. O lema básico que inspira e caracteriza a fenomenologia é o busca ou volta "às coisas mesmas, procurando com isso a superação da oposição entre realismo e idealismo, entre o sujeito e o objeto, a consciência e o mundo. Toda consciência é consciência de alguma coisa; a consciência se caracteriza

\footnotetext{
${ }^{52}$ Isto não significa dizer que o neotomismo, o positivismo e o funcionalismo tenham deixado de influenciar.

${ }^{53} \mathrm{~A}$ formação profissional do assistente social, no Brasil, apresenta quatro dimensões que refletem a dinâmica da profissão: “um momento inicial que se volta para uma formação profissional eminentemente doutrinária e religiosa, fundamentando-se, principalmente, na filosofia neotomista; um momento essencialmente marcado pela busca do avanço técnico da profissão, norteado pela necessidade de uma ação eficaz voltada para o ajustamento do indivíduo a uma sociedade harmônica e justa, pautando-se, sobretudo, pela sociologia positivista; um momento de aliança do Serviço Social, ainda tecnicista e asséptico, com o desenvolvimento. Esboça-se, atualmente, uma tendência de capacitação do assistente social para uma visão estrutural e conjuntural da sociedade, em função de um projeto profissional capaz de deslocar o centro de compromisso da profissão da classe dominante para a classe oprimida, que, historicamente, tem constituído sua clientela” (SILVA E SILVA, 1984).

${ }^{54} \mathrm{O}$ ponto comum entre elas é a postura como analisam problemas da realidade social e da alienação da consciência.
} 
exatamente pela intencionalidade" (MARCONDES, 2006:258). Sendo assim, caberia à fenomenologia descrever, compreender e interpretar os fenômenos que se apresentam à percepção. Propor a extinção da separação entre "sujeito" e "objeto" é algo que se opõe ao pensamento positivista do século XIX (daí atrair a Reconceituação). O método fenomenológico se define como uma volta às coisas mesmas, isto é, aos fenômenos, aquilo que aparece à consciência, que se dá como objeto intencional. Seu objetivo é chegar à intuição das essências, isto é, ao conteúdo inteligível e ideal dos fenômenos, captado de forma imediata. Se toda consciência é consciência de alguma coisa, a consciência não é uma substância, mas uma atividade constituída por atos (percepção, imaginação, especulação, volição, paixão), com os quais visa algo. As essências ou significações (noema) são objetos visados de certa maneira pelos atos intencionais da consciência (noesis). Afim de que a investigação se ocupe apenas das operações realizadas pela consciência, é necessário que se faça uma redução fenomenológica ou epoché, isto é, que se coloque entre parênteses toda a existência efetiva do mundo exterior. Pois seria na prática da fenomenologia que se efetuaria o processo de redução fenomenológica (eidética) o qual permite atingir a essência do fenômeno. As coisas, segundo Husserl, caracterizam-se pelo seu inacabamento, pela possibilidade de sempre serem visadas por noesis novas que as enriquecem e as modificam (CARVALHO, 1991) ${ }^{55}$.

Uma outra característica que tornou a fenomenologia importante ao Serviço Social é o fato de ela enfatizar o(s) significado(s) que as pessoas dão às coisas e à vida. Os significados são obtidos através das descrições dos depoimentos e, desse modo, surge a grande relevância da entrevista ser utilizada na modalidade fenomenológica como instrumento de obtenção dos mesmos (anamnese). A entrevista é considerada como um encontro social, com características peculiares como a empatia e a intersubjetividade, onde ocorre a penetração mútua de percepções. É um esforço por buscar colocar-se no lugar do outro. A entrevista fundamentada na metodologia fenomenológica busca uma linguagem que seja a 'fala originária', que possibilita a mediação com o outro e a comunicação com o mundo. Carvalho (1991) trabalha a temática fenomenológica destacando a necessidade de percepção do pesquisador no sentido de: $i$ ) ver e observar, sem estar fechado em uma perspectiva causal; ii) interpretar compreensivamente a linguagem do cliente e a percepção dessa linguagem como veículo de significações; iii). Perceber o gesto do cliente em seu movimento. Sendo assim, a fenomenologia seria inspiração para o desenvolvimento de análises do agir moral, da vida social, do trabalho...

\footnotetext{
${ }^{55}$ Um outro pensador muito importante para a evolução da fenomenologia foi o filósofo francês Merleau-Ponty.
} 


\section{b) Marxismo:}

Marxismo é o conjunto de idéias filosóficas, econômicas, políticas e sociais elaboradas a partir do pensamento de Karl Marx e Friedrich Engels e desenvolvidas por seus seguidores. Interpreta a vida social conforme a dinâmica da luta de classes e prevê a transformação das sociedades de acordo com as leis dialéticas do desenvolvimento histórico do sistema produtivo. Mais do que uma filosofia, o marxismo é a crítica radical da Filosofia, principalmente do sistema filosófico idealista de Hegel. Enquanto para Hegel a realidade se fazia filosofia, para Marx a Filosofia precisaria incidir sobre a realidade. $O$ núcleo do pensamento de Marx é sua interpretação do homem e de suas necessidades. $A$ história se iniciaria com o próprio homem que, na busca da satisfação de necessidades, trabalha sobre a natureza. Esta se transforma e transforma o homem pelo trabalho. $O$ homem se descobre como ser social produtivo e passa a ter consciência de si e do mundo. Percebe aí que a história é processo de criação humana pelo trabalho, gerando valor de uso. Porém, o advento e expansão do capitalismo potencializaram o sentido de alienação e exploração do trabalho, tendendo-o a reduzir a valor de troca (MARX, 1994) ${ }^{56}$.

Dois elementos centrais do marxismo são: o materialismo dialético - para o qual a natureza, a vida e a consciência se constituem de matéria em movimento e evolução permanente - e o materialismo histórico, para o qual o modo de produção é a base determinante (estrutura) dos fenômenos históricos e sociais, inclusive as instituições jurídicas e políticas, a moralidade, a religião e as artes (superestrutura). A teoria marxista desenvolve-se em quatro níveis de análise - filosófico, econômico, político e sociológico -, que giram em torno da revolucionária tese ou idéia central de mudança ou transformação do mundo. Interpretada por diversos seguidores, a teoria marxiana da filosofia da ação tornou-se uma ideologia que se estendeu a regiões, espaços e culturas de todo o mundo e foi acrescida de características dos contextos nacionais. Surgiram versões como as dos partidos comunista francês e italiano, o marxismo-leninismo na extinta União Soviética, as experiências no leste europeu, o maoísmo na China e Albânia e as interpretações socialistas da Coréia do Norte, de Cuba e dos partidos únicos africanos - em que se mistura até com ritos tribais. As principais correntes políticas originárias da tradição marxista foram: social-democracia, bolchevismo e o esquerdismo (MARCONDES, 2006).

A vertente marxista de análise é, preponderantemente, a tendência mais utilizada e citada na formação, nos documentos e entidades do Serviço Social contemporâneo. As categorias de leitura crítica da realidade que enfocam o trabalho e o modo de produção

\footnotetext{
${ }^{56}$ Já discutimos outros conceitos de Marx em capítulos anteriores, como na abordagem teórico-metodológica, p.ex.
} 
capitalista, bem como a percepção do desenvolvimento do capital e suas formas contraditórias de atuação constituem o cerne dos estudos sobre o qual o Serviço Social vem refletindo com frutos. Também a categoria trabalho, utilizada em Marx, e as relações sociais estabelecidas a partir dela, representam o fundamento para a compreensão da realidade onde se inserem os assistentes sociais e o seu vínculo com os processos de produção. A emergência e a expansão do marxismo no Serviço Social seriam, conforme José Paulo Netto, necessidades prementes e únicas para que a profissão pudesse articular os anseios da perspectiva de classe do proletariado com a legitimação do arsenal teórico-metodológico da categoria de assistentes sociais, porquanto: "nos marcos da sociedade burguesa, essa conjunção é garantida apenas pelo ponto de vista de classe do proletariado e pelo projeto teórico-metodológico crítico-dialético" (NETTO, 1992:138).

Outra relevância nova que a concepção clássica marxista trouxe aos novos objetivos do Serviço Social refere-se à valorização da perspectiva dialética da totalidade ${ }^{57}$, em contraposição às concepções e ações de sentido individualista (psicologização) e fragmentário que eram típicas no Serviço Social tradicional. Totalidade não significa, em termos dialéticos, a soma de todas as situações individuais que se dão na realidade, nem tampouco uma situação composta por fenômenos mais relações. Por sua vez, aspirar conhecer a totalidade não pode ser confundido com lograr obter o conhecimento de tudo o que está na realidade visível e invisível. Totalidade significa que nenhum fenômeno é apenas manifestação individual e isolada, mas sim algo estruturalmente relacionado e historicamente situado que, embora inscrito e manifestado através de particularidades, insere-se no conjunto de relações condicionantes e determinantes de uma sociedade. A vida em sociedade seria "produção e reprodução de relações sociais historicamente determinadas e das contradições que as permeiam" (IAMAMOTO e CARVALHO, 1996:22). Tal percepção alterou, por exemplo, as noções existentes no meio profissional acerca das causas da pobreza e a respeito do papel e melhor operacionalização das políticas sociais.

De fato, desde a Reconceituação, os questionamentos da moral e da ordem social burguesa vigente resultaram numa forte politização da intelectualidade formadora do Serviço Social. As progressivas aproximações do Serviço Social às categorias da dialética marxista possibilitaram a construção da verdadeira identidade profissional, e que com ela: "a profissão caminhará no sentido de participar coletivamente do processo de produção de novas relações sociais e de criação de alternativas peculiares de enfrentamento da relação capital-trabalho. Rompendo com a alienação e superando suas próprias origens

\footnotetext{
${ }^{57}$ Tal conceito pode ser encontrado de forma mais profunda no texto O método da Economia Política, dos Grundrisse.
} 
burguesas, o Serviço Social dará o passo inicial para um novo momento da prática profissional, produzida por uma categoria crítica, politicamente assumida e capaz de lutar por sua identidade, não como ansiedade grupal ou obsessão pelo idêntico, mas como luta social pela transformação da sociedade" (MARTINELLI, 2006:159).

Por outro lado, também cabe ponderar e reconhecer que, por muitas vezes, as distintas leituras de Marx e do seu questionamento em relação à lógica burguesa também abriram espaços para discussões acaloradas e não raras equivocadas no interior da profissão. Algumas concepções até geraram discursos exaltados de cunho revolucionário que, na prática, só convertiam a busca da transformação incisiva das relações sociais em mero reforço da associação da profissão ao messianismo e militantismo (FALCÃO, 1981).

Com o fim do governo militar, o processo de reconceituação pôde continuar e, em 1979, a perspectiva crítico-dialética ganhou força suficiente para impulsionar uma reforma nos currículos que formariam os futuros assistentes sociais das décadas posteriores. Em 1982, com sua aprovação, a árdua tarefa de disseminá-lo foi iniciada. Tratou-se de um período de transição para um governo democrático, que se reflete também na profissão, que busca as bases teóricas e filosóficas que faltavam. Um evento desta abrangência encontrou muitas dificuldades e retrocessos, apesar de, em última instância, continuar representando um amadurecimento na profissão. Muitos cursos universitários das décadas de 1970 e 1980, no empenho que se tornou mais severo em qualificar a capacidade científica e de produção de conhecimento dentro do Serviço Social, adotaram linhas teóricas e perspectivas contemporâneas da época. Entretanto, em outras unidades de ensino, os embates internos entre as diferentes tendências conservadoras versus as tendências politizadas/marxistas resultaram em currículos adaptados que possuem o material defendido nas convenções de 1979, mas não contém o espírito ou a discussão madura de seus conteúdos. Nos anos 90 - tempos neoliberais - houve um adensamento das reflexões e tendências marxistas em geral na profissão. Novas diretrizes curriculares foram construídas e adotadas através do caminho da busca de entendimento e do diálogo democrático. Pesquisas e congressos foram realizados para avaliar o andamento e a qualidade dos novos currículos, realizando ajustes e capacitando profissionais. Este é um processo que ainda se encontra em andamento e caracteriza a profissão do Serviço Social como sempre sujeita e aberta às mudanças e mutações, em uma velocidade por vezes tão rápida quanto à de seu objeto atribuído: as manifestações da questão social ${ }^{58}$.

\footnotetext{
58 "O elemento de continuidade entre o atual projeto da formação profissional e o currículo de 1982 é a adoção de uma teoria social crítica e de um método que permita a apreensão do singular como expressão da totalidade social” (KOIKE, 1999:11).
} 


\section{0 - O Serviço Social na contemporaneidade}

Novos e complexos desafios apresentam-se na contemporaneidade da profissão, exigindo da categoria maturidade e convicção do seu projeto ético-político (KOIKE, 1999). Em 2006, o Serviço Social completou 70 anos no Brasil. Conforme vimos, a profissão surgiu das requisições e/ ou demandas da nova dinâmica social posta pelo capitalismo monopolista frente às expressões da questão social, do incremento da industrialização e das respostas das classes e do Estado à desigualdade social via políticas sociais. Da gênese até meados dos anos sessenta, a profissão esteve fortemente orientada pelas teorias neotomistas, positivistas, funcionalistas e por ideologias desenvolvimentistas, além dos trabalhos de caso, grupo e comunidade. O movimento de Reconceituação significou o desencadeamento do início do processo de ruptura (ao menos na América Latina) do Serviço Social com a chamada herança conservadora. Desde essa época e de forma gradativamente maior, a categoria profissional vem buscando assumir - fundamentada por uma teoria social crítico-dialética - a identidade com as lutas dos trabalhadores e com a necessidade de estabelecimento de novos padrões de sociedade, encarnados no cotidiano profissional e em outros espaços pela busca da democracia e da justiça social.

Não obstante, cenários complexos - sejam aqueles herdados do passado ou outros oriundos de novas demandas - delineiam-se no horizonte da profissão, atingindo de forma prejudicial não somente ao Serviço Social e às suas intenções, mas a todas as profissões, ramos e espaços. Sobrevivemos, há alguns anos, sob a égide gladiadora do capitalismo de orientação neoliberal. Notam-se, em todo o globo, profundas mutações decorrentes dos postulados e imposições neoliberais, que potencializaram mudanças nas esferas do Estado, da organização e produção, dos processos e especializações do trabalho, da divisão social e das relações sociais (ANTUNES, 1995; IAMAMOTO, 1998; SILVA, 2000).

Inserido nestes processos instáveis do mercado competitivo globalizado - onde "tudo que é sólido desmancha-se no ar" -, o Serviço Social ${ }^{59}$ vem experimentando dificuldades e reduções, começando pela formação profissional e estendendo-se às necessidades de recursos materiais e humanos mais básicos na rotina das instituições. O desemprego, os contratos temporários, a invasão de outros profissionais e de agentes voluntários em atividades que demandam por excelência os conhecimentos dos assistentes sociais, o trabalho precarizado e a lógica perversa de fragmentação, minimização e/ou retração das políticas e dos direitos sociais vêm dilapidando muitas conquistas históricas, tanto da

\footnotetext{
${ }^{59}$ Segundo dados do Conselho Federal de Serviço Social (CFESS) contamos atualmente cerca de 63 mil profissionais.
} 
classe trabalhadora quanto dos assistentes sociais (GRAVE, 2000). Os assistentes sociais reunidos no $35^{\circ}$ Encontro Nacional CFESS/CRESS (setembro de 2006) em Vitória - ES apontaram, dentre outros desafios postos à profissão, algumas preocupações ${ }^{60}$ :

1- A necessidade urgente de se reorientar a política econômica no sentido de favorecer os interesses nacionais e demandas da maioria da população, ao contrário de transferir recursos para o capital financeiro, penalizando o emprego, os direitos e a renda;

2 - A premência de frear a precarização da formação profissional, que vem ocorrendo por meio da expansão acelerada de cursos de Serviço Social privados ${ }^{61}$, presenciais e à distância, bem como ao sucateamento das universidades públicas, algo que tem fortes implicações para a qualidade final dos serviços prestados à população;

3 - A urgência da realização de investimentos significativos nas políticas sociais, rompendo "com a orientação focalista e seletiva das mesmas e instituindo um quadro efetivo de trabalhadores do setor público" (CFESS/CRESS, 2006:02).

Analisemos criticamente, a seguir, algumas características destes novos cenários, donde surgem e/ou são reeditados com nova roupagem retórica e fôlego impressionantes velhas modalidades de intervenção e de concepções que recuperam o assistencialismo, a solidariedade e o voluntarismo como alternativas de resolução aos 'problemas sociais'.

\section{1 - Neoliberalismo, terceiro setor e refilantropização da questão social}

Sem a pretensão de citar ou tecer todas as críticas, ponderações e análises acerca destes três itens consubstanciais ${ }^{62}$, as suas repercussões no Serviço Social e, no caso deste estudo, sobre as concepções e percepções acerca da profissão, cabe alinhavar algumas reflexões que contribuirão mais adiante para entendermos como a ascensão e expansão destas ideologias e discursos - de essência capitalista - penetram a fundo na sociedade (e, logicamente, nos jovens que ingressam na faculdade), muitas vezes acobertados por discursos despolitizados e acríticos de evocação de solidariedade e ajuda àqueles que se encontram em situações de exclusão social ('mais vulneráveis').

\footnotetext{
${ }^{60}$ Além de outras manifestações: “Em tempos de predomínio da concentração da propriedade e da riqueza socialmente produzida, que geram a violência, a barbárie, as atitudes individualistas e antiéticas, e a degradação da forma de fazer política, os (as) assistentes sociais brasileiros (as) reafirmam sua luta pela construção de novas formas de organização da sociedade. A busca permanente por uma sociedade menos desigual, e por um mundo onde o respeito ao diferente possa se expressar, também faz parte do cotidiano dos (as) assistentes sociais, ainda que esse cotidiano seja marcado por péssimas condições de trabalho e muitas vezes pelo desrespeito ao seu trabalho por parte de instâncias dirigentes. Neste dia 15 de maio o Conselho Federal de Serviço Social rende profunda homenagem a todos (as) os (as) assistentes sociais brasileiros (as), e conclama a todos a continuarem na luta pelas reais transformações na sociedade em que vivemos” (CFESS, 2006).

${ }^{61}$ É preciso destacar que a crítica em questão recai não pelo fato de o setor privado abrir cursos de Serviço Social, mas pelo processo de aprovação e oferta de cursos de graduação particulares e/ou à distância que faz parte do movimento da reforma universitária, que tem por base o privilégio dos interesses do mercado em detrimento do ensino público.

${ }^{62}$ Embora seja uma apropriação de um termo teológico, consubstancial neste sentido significa identificar o neoliberalismo, a ascensão do $3^{\circ}$ setor e a refilantropização da questão social como partícipes da mesma essência e movimento.
} 


\section{a) Neoliberalismo}

O neoliberalismo ${ }^{63}$ pode ser entendido como uma doutrina político-econômica que representa uma tentativa de retomar os princípios do liberalismo clássico às condições da economia contemporânea. As suas origens remetem à Escola Austríaca dos finais do século XIX, que tinha como representantes mais conhecidos Friedrich Von Hayek considerado o propositor da sua base filosófica e econômica - e Ludwig Von Mises. A Escola Austríaca se opôs ao modelo keynesiano de proteção social e ao Estado de BemEstar Social (Welfare State). Como a escola liberal clássica, o ideário neoliberal sustenta que a vida econômica seria regida por uma 'ordem natural', constituída por livres decisões individuais, cuja mola mestra é o mecanismo das leis do mercado ${ }^{64}$, que devem ser estimuladas e/ou favorecidas pelo Estado. Constatando falhas inerentes às atividades governamentais (excessiva burocracia, corrupções, pouca eficácia, etc) que, em última instância poderiam levar a governos autocráticos, tal corrente de pensamento político defende a instituição de um sistema de governo em que os interesses dos indivíduos tenham mais importância do que o Estado, argumentando que quanto menor a participação do Estado na economia maior é o poder dos indivíduos e mais rapidamente a sociedade pode se desenvolver e progredir, para o bem dos cidadãos. (FALEIROS, 2000).

Essa assertiva, que se assenta na tônica individualista como saída para a eficiência, seria confirmada na insidiosa, suposta, encobertadora e acrítica tese de que os países de maior desenvolvimento econômico são aqueles em que há menor ingerência estatal na vida privada ${ }^{65}$. Tal concepção manifesta-se, citando apenas como exemplos: nas constantes intervenções de organismos internacionais (FMI, BIRD, etc) nos países; na valorização da competição doentia entre pessoas e empresas, visando empregabilidade e sustentabilidade no mercado cada vez mais exigente; no estímulo ao empreendedorismo, gerando mercados diversificados e informais; na lógica da capitalização dos seguros privados previdenciários, onde cada um 'decide' quanto poupará para a sua velhice; nas reformas previdenciárias e tributárias operadas nos países subdesenvolvidos, na expansão de planos de saúde privados; no sucateamento da educação publica e favorecimentos às instituições particulares; na competição econômica em escala mundial (globalizada) como elemento seletivo, gerador e promotor da eficiência (FLEURY, 2004).

\footnotetext{
${ }^{63}$ Defensores desta doutrina rejeitam o termo neoliberal, preferindo-o denominar apenas liberalismo, por ser continuação do liberalismo clássico. Neoliberal tende a ser, pois, um termo mais usado pelos críticos e principalmente pelas correntes de esquerda. Na afirmação da existência de 'neoliberais', a utilização do prefixo 'neo' refere-se menos a uma nova corrente do liberalismo e mais à aplicação dos preceitos liberais consagrados num contexto histórico diverso daquele no qual foram formulados, isto é, na contemporaneidade (definição do site Wikipedia).

${ }^{64}$ Ainda que defenda em muitos casos o seu disciplinamento, mas não para asfixiá-lo, mas para garantir-lhe sobrevivência.

${ }^{65}$ Ainda que propaguem o neoliberalismo para todo o globo, os países desenvolvidos não o assumem plenamente para si.
} 
Por isso, a filosofia neoliberal acredita que a desigualdade social é, além de fruto da incompetência individual (algo natural e de ordem moral), uma conseqüência da falta de liberdade e gestão da parte do Estado, via controle de áreas estratégicas, financiamento de políticas públicas e sociais e bloqueios às demandas do mercado. Com a crise do petróleo de 1973 e o fim do padrão dólar-ouro seguido pela forte onda inflacionária que surpreendeu os Estados de Bem-Estar Social, o liberalismo gradativamente voltou à cena, sob a alcunha de neoliberalismo. Denunciou-se a inflação como resultada do aumento da oferta de moeda pelos bancos centrais. Responsabilizaram os impostos elevados e os tributos excessivos, juntamente com a regulamentação das atividades econômicas, como os culpados pela queda da produção. A solução seria, pois, a redução gradativa do poder do Estado, com diminuição de tributos, privatização de empresas estatais e redução do seu poder de impor e autorizar preços. Ademais, diminuindo ou neutralizando a força dos sindicatos e reduzindo custos com direitos trabalhistas, abrir-se-iam perspectivas de emprego e investimento, atraindo investidores (ou especuladores) de volta ao mercado e, por conseqüência, reduzindo o desemprego. O primeiro governo ocidental democrático a se inspirar em tais princípios foi o de Margaret Thatcher (a "dama de ferro") na Inglaterra, a partir de 1980. Persuadindo o Parlamento inglês da eficácia dos ideais neoliberais, aprovou leis que revogavam muitos privilégios concedidos aos sindicatos, privatizou empresas estatais, priorizando a tributação regressiva. Procurou estabilizar a moeda. 0 governo Thatcher, conservador, serviu de modelo para governos neoliberais posteriores.

Na América Latina, o Chile foi pioneiro na adesão à ofensiva neoliberal. No Brasil, embora iniciado nos dois governos anteriores (Sarney e Collor) ${ }^{66}$, foi nos dois governos de Fernando Henrique Cardoso que o projeto de orientação política e econômica neoliberal alcançou força e expansão ${ }^{67}$. Desde o inicio do primeiro mandato, Fernando Henrique buscou a abertura da economia aos capitais internacionais (sobretudo especulativos), inclusive eliminando monopólios do Estado. Privatizou empresas e serviços estatais. Reduziu muitos direitos com a desregulamentação das leis trabalhistas. Submeteu o país aos empréstimos e monitoramentos do Fundo Monetário Internacional (FMI). Já no segundo mandato, o governo aprovou - mesmo com resistências internas -, sob o discurso de um suposto e apocalíptico déficit, uma reforma previdenciária que, em suma, aumentou o tempo de contribuição necessária para aposentadoria, extinguiu muitos direitos e abriu caminhos para o avanço da previdência privada e seus regimes de capitalização.

\footnotetext{
66 “Collor promoveu uma abertura econômica, acelerou o processo de privatização que vinha sendo feito por Sarney e demitiu 65 mil funcionários” (FALEIROS, 2000:51).

${ }^{67}$ O primeiro mandato de Lula (eleito em 2002) também seguiu, em muitos aspectos, os postulados da agenda neoliberal.
} 


\section{b) Terceiro Setor e a refilantropização da questão social}

Olhar mais dialético e menos tomado por paixões ideológicas lançadas sobre estes temas geralmente reconhece que o dito terceiro setor é categoria bastante heterogênea e ambivalente que, em virtude das múltiplas modalidades, interesses, manifestações e 'bandeiras' que envolve, não pode ser classificado apenas como adequado aos interesses capitalistas neoliberais ou, de outro modo, como alternativa emancipatória comprometida com os projetos populares. De modo geral, o terceiro setor, herdeiro das marcas das contradições da sociedade capitalista que o cria, tende a agrupar tanto aquelas iniciativas conservadoras, fragmentárias, acríticas e mantenedoras da ordem vigente quanto também alternativas criativas, fundamentadas em percepções críticas da sociedade e do capitalismo que, de algum modo, contribuem para a cidadania, a construção do controle social democrático e a qualidade de vida da população. Ademais, em termos teóricos, existem muitas interpretações acerca dos sentidos, significados e categorias evocadas no terceiro setor. Um dos conceitos mais discutíveis é o de sociedade civil, que inclui desde a tese gramsciana (usada nos anos 70 e 80 ) de 'espaço de organização e formação de uma consciência transformadora' até o simples reducionismo ${ }^{68}$ (mais recente) de percebê-la como 'aquela parcela ou esfera da sociedade - que não se vincula ao Estado nem ao mercado - composta por cidadãos engajados em ações voluntárias, ainda que eventuais'. Porquanto, cabe perceber então que: "o termo sociedade civil também não é homogêneo e nem é composto por atores com o mesmo entendimento dos problemas sociais, políticos, econômicos e culturais da sociedade (...). Há, portanto, diferentes projetos políticos sobre a dinâmica de desenvolvimento da sociedade" (GOHN, 2002:319). Uma crítica importante que se faz aos entendimentos recentes mais divulgados acerca desta categoria refere-se à despolitização que o entendimento corrente traz à questão social, alegando-se que neste viés a sociedade civil é "lida como um conjunto de organizações diferenciadas, mas complementares, destituída de contradições entre interesses de classes e seus segmentos, encobrindo e esvaziando conflitos sob a retórica evocação da solidariedade. Parece atualizar inspirações clássicas da sociologia positivista na análise da sociedade moderna, que reforçam os elos de coesão social, com forte apelo à moral, em detrimento da visibilidade e reconhecimento das tensões sociais. Assim, a sociedade capitalista passa a ser lida sob a ótica da comunidade, numa regressão conservadora, que salienta os laços de coesão em detrimento das contradições" (IAMAMOTO, 2000:32).

\footnotetext{
${ }^{68}$ Um destes reducionismos (adequados ao pensamento neoliberal) afirma que o terceiro setor não é, assim, nem público nem privado, mas sim uma junção do setor estatal e do setor privado para uma finalidade maior: suprir as falhas do Estado e do setor privado no atendimento às necessidades da população, numa relação conjunta (GOHN, 2002).
} 
Feitas as ponderações, podemos dizer que, em termos gerais, o terceiro setor pode ser percebido como uma terminologia sociológica que dá significado a todas as iniciativas privadas de utilidade pública com origem na chamada sociedade civil. Fundamenta-se na idéia da cidadania como "participação civil, de exercício da civilidade, de responsabilidade social dos cidadãos como um todo" (idem: 316). A expressão é uma tradução de third sector, vocábulo muito utilizado nos Estados Unidos que visa definir as organizações sem vínculos diretos com o primeiro setor (Estado) e o segundo setor (mercado). Dentro das organizações que fazem parte do terceiro setor, podemos citar as ONGs (Organizações Não-Governamentais), as entidades filantrópicas e religiosas, as OSCIPs (Organização da Sociedade Civil de Interesse Público), os conselhos, fóruns, redes e articulações entre sociedade civil e representantes do poder público, organizações sem fins lucrativos e outras formas de associações civis sem fins lucrativos. A sua composição é, assim, majoritariamente lastreada por organizações sem fins de lucro, criadas e mantidas por participação voluntária, de natureza privada, não submetida ao controle direto do Estado ${ }^{69}$.

Importa também perceber que, no contexto da ascensão do terceiro setor, um outro fenômeno ocorre: a refilantropização e remercantilização da questão social. Por muitas vezes, as atuações e diretrizes das instituições do chamado terceiro setor representam continuidade ou retomada de antigas práticas tradicionais da caridade e filantropia, só que executadas não mais exclusivamente por instituições religiosas (devido à secularização) ou, ainda, reprodução de visões segmentadoras e setorializadas da realidade social, algo típico de tradições positivistas, neopositivistas, funcionalistas, estruturalistas e sistêmicas. Estudiosos vinculados à tradição marxista apontam nestes fenômenos forte adequação e funcionalidade ao projeto neoliberal de reestruturação do capital, sobretudo pela sugestão privatizante que contém as muitas críticas à ineficiência do Estado como motivo para valorizar as ações do terceiro setor, assim como as do mercado (responsabilidade social). Destarte, a ascensão do terceiro setor teria sido promovida por setores ligados ao grande capital e assimiladas pela conivência de 'esquerdas resignadas'. Tais estratégias sibilinas, instrumentalizadoras e acobertadoras da contradição básica capital-trabalho representam, pois, derrotas: "no que se refere ao afastamento do Estado das suas responsabilidades de resposta às seqüelas da questão social, sendo, portanto, um conceito ideológico portador da função de encobrir e desarticular o real" (MONTAÑO, 2002:16).

\footnotetext{
${ }^{69}$ Existem discussões de quais seriam os reais contornos do $3^{\circ}$ setor, pois suas organizações utilizam recursos do Estado e do Mercado. Além disso, o trabalho voluntário - no qual uma pessoa doa o seu tempo e talento em prol de uma causa solidária - implicaria em um investimento econômico do mesmo sem a necessidade de estar vinculado a uma organização.
} 
Um outro aspecto preocupante nesta questão é que, na proporção inversa em que cresce o terceiro setor, retraem-se a formulação, gestão e financiamento do Estado às políticas públicas e sociais. Ocorrem muito mais, aliás, ampliações das transferências de responsabilidades para a sociedade civil no campo da prestação de serviços sociais, sobretudo travestidas sob as aparências das parcerias entre governos e organizações nãogovernamentais $^{70}$. E, ainda que se possam encontrar neste contexto virtudes e experiências realmente úteis às causas e anseios da população - conselhos, movimentos sociais e populares, p.ex. -, prevalecem e são contempladas amplamente as iniciativas afinadas com o sentido neoliberal de programas seletivos e focalizadas (GOHN, 2002).

Enfim, cabe citar algo fundamental ao contexto deste estudo. Nota-se, nos últimos anos, o ressurgimento renovado e vigoroso daquelas idéias que colocam as intervenções e programas sociais como ajuda, doação e/ou fruto da solidariedade e bondade de quem os executa, abandonando-se assim o horizonte de conquista e ampliação dos direitos e da autonomia das populações assistidas. Estes atributos - feitiços da ajuda, como alguém já disse - repercutem mesmo em ambientes historicamente marcados pelas construções e elaborações críticas, como os sindicatos e universidades, incluindo por isso mesmo até o Serviço Social, tanto seus profissionais formados quanto estudantes graduandos. Além do cultivo da ingênua (ou maldosa) e acrítica visão de política social voluntária - ou outras propostas do tipo renda mínima - para dar conta de maiorias marginalizadas, bem como a propagação da idéia dicotômica de sociedade desvinculada de intervenções de Estado e mesmo de mercado, algumas farsas também surgem nas propostas vigentes, começando pelo encobrimento do pano de fundo capitalista neoliberal que as envolvem e inspiram. $O$ que cabe notar nestas propostas com fachadas solidárias vindas de cima para baixo são os efeitos de poder que se alocam de forma sutil, manhosa e ardilosa (DEMO, 2002) ${ }^{71}$. Porquanto: "Ajuda, em termos sociológicos, tende a ser presente de grego. Porque, no contexto social, a ajuda geralmente favorece mais a quem ajuda do que ao ajudado. Em termos mais ostensivos, ajuda é quase sempre estratégia sibilina de vantagem, encoberta sob a capa de pretensa boa vontade e solidariedade. O ajudado, além de levar muito pouco, caracteristicamente restos ou mesmo nada, torna-se presa da ajuda. Ser ajudado sem perder a condição de sujeito autônomo é quase milagre social" (DEMO, 2000:185).

\footnotetext{
70 “Nos anos 90, as ONGs adquirem maior visibilidade na mídia e no espaço político. Hoje atingem o montante de quatro a cinco mil organizações no país, prestando-se a várias apropriações ideológicas e discursivas (...) Atuam na formulação, gestão e avaliação de programas e projetos sociais em áreas como: violência e relações de gênero, criança e adolescente, movimentos urbanos, meio ambiente, questão étnica, tecnologias alternativas na agricultura, sindicalismo rural e pequena produção familiar. Desenvolvem atividades de assessoria, pesquisa e informações, educação popular, campanhas e denúncias, entre outras, em que participam os assistentes sociais ao lado de outros profissionais” (IAMAMOTO, 2000:123).

${ }^{71}$ Potencializando assim, no dizer de Pedro Demo, o cultivo da massa de manobra e/ou pobreza política da população.
} 


\section{2 - O projeto ético-político profissional}

Em face de todos os desafios sóciopolíticos, culturais, econômicos, de vínculos históricos, transformações, influências e demais variáveis possíveis já citadas, o projeto ético-político profissional aparece - em termos metafóricos - como perene recorrência na literatura especializada contemporânea como um 'farol' ou 'bússola' que deve orientar os assistentes sociais em suas intenções e gestos. Interessante notar, porém, que o debate acerca do que se convencionou chamar projeto ético-político é algo mais marcante a partir dos anos 90, embora suas raízes estejam na transição da década de 1970 para a de 1980, quando a recusa do conservadorismo e autoritarismo - estimulada pelas lutas em busca da democratização no país - aumentou no meio profissional (NETTO, 1999). Logicamente, este processo (plural) de construção do projeto ético-político profissional inclui o redimensionamento e ressignificação das modalidades teórico-metodológicas, dos instrumentos e da instrumentalidade, das visões e posicionamentos acerca das relações sociais e da relação capital/trabalho e dos paradigmas norteadores das políticas sociais. Em 1986, o novo Código de Ética Profissional ${ }^{72}$ já sinalizava a ruptura da profissão com as práticas e visões tradicionais e conservadoras. Todavia, devido a carências em torno das dimensões éticas e profissionais, foi necessária uma revisão e amadurecimento das discussões nele constantes. Neste sentido, em 1993 foi apresentado o Código que hoje vigora, coroando princípios como a liberdade, a autonomia e emancipação dos sujeitos.

Neste mesmo sentido, o projeto ético-político do Serviço Social está vinculado aos princípios de reconhecimento da autonomia, emancipação e plena expansão dos indivíduos presentes no Código de Ética da profissão, cuja finalidade central é contribuir articulado a outras profissões - para a promoção da cidadania, da equidade e da justiça social na perspectiva de universalização dos direitos sociais e compromisso qualitativo com as políticas sociais. Assim: "o projeto profissional vincula-se a um projeto societário que propõe a construção de uma nova ordem social, sem dominação e/ou exploração de classe, etnia e gênero" (NETTO, 1999:105). Busca-se a formação e atuação profissional (científica, formal, institucional e cotidiana) que fortaleça um "projeto profissional parceiro da eqüidade e da liberdade, voltado para assegurar um exercício profissional de qualidade, competente e crítico, nos níveis de assessoria, planejamento, negociação, da pesquisa e ação direta, estimulador da participação dos cidadãos na formulação, gestão, implementação e avaliação dos programas e políticas sociais" (IAMAMOTO, 1998:17).

\footnotetext{
${ }^{72}$ Os anteriores datavam de 1947, 1965 e 1975.
} 


\section{3 - O perfil dos assistentes sociais contemporâneos}

O contexto de profundas e intensas mutações, reconfigurações e reestruturações políticas, socioeconômicas, ideológicas e culturais ocorridas nos últimos anos propiciaram e exigiram (do Serviço Social) grandes desafios e renovada ousadia. O contorno geral extremamente dialético, complexo, ambíguo, ambivalente e não-linear deste tempo, marcado por avanços da mercantilização das relações sociais, tantas incertezas e instabilidades (pós-modernidade), regressão de direitos e de utopias repercute, ao final, tanto em avanços quanto em retrocessos significativos para a profissão e suas intenções. Subsistem aí aspectos positivos e negativos. É certo que tudo isto contribui para a maturação, melhor discernimento e separação entre "o joio e o trigo" no interior da categoria que, de forma coesa e coerente, reafirma e assume o seu projeto ético-político.

A pesquisa Perfil Profissional do Assistente Social no Brasil ${ }^{73}$ (2005) revela, dentre outros temas, dados interessantes acerca de tendências de mudanças importantes - mas também de permanências surpreendentes - naquilo que podemos chamar de perfil médio dos mais de 60 mil profissionais de Serviço Social ${ }^{74}$. Vejamos algumas informações:

a) As mulheres continuam sendo a maioria (97\%) na profissão. Ainda que se tenha procurado nas últimas décadas desfazerem-se algumas associações e estereótipos que ligavam o caráter e escolha da profissão a uma suposta afinidade eletiva com um 'instinto de maior doação' das mulheres ou ainda pelas práticas assistenciais incumbidas 'às moças de boas famílias', o fato é que persistem fortes vínculos entre mulheres e Serviço Social. Por outro lado, é possível que em alguns anos esta tendência sofra retrações. Isto se explica pelo fato de que $63 \%$ dos assistentes sociais estão na faixa etária entre 34 e 59 anos de idade, o que pode significar que a porcentagem seja representação de realidades de épocas anteriores, pois a maioria destes profissionais graduou-se em outros contextos.

b) A religiosidade ou participação efetiva em uma religião continua muito forte entre os profissionais de Serviço Social $(76 \%)$, revelando dentre outras coisas resistências à onda de secularização e indiferença religiosa (como ocorre em países da Europa e Ásia) e, também, às ligações da profissão com o materialismo dialético, tendencialmente ateu. Embora 67,65\% dos profissionais se declarem católicos, observa-se que a distribuição por religiões ou seitas acompanha o sentido de diversificação religiosa da sociedade geral.

\footnotetext{
${ }^{73}$ Divulgada em 2005 pelo Conselho Federal de Serviço Social (CFESS). Foi realizada em regime de parceria com a Universidade Federal de Alagoas e com os Conselhos Regionais de Serviço Social (CRESS) de todo o país.

${ }^{74}$ Fomos protagonistas da conquista da Constituição Federal Brasileira de 1988, na qual são assegurados direitos sociais nunca antes conquistados nessa sociedade. Entre vários destes, a Assistência Social se transforma em política pública, formando junto com a Saúde e Previdência, o tripé da Seguridade Social.
} 
c) Quanto à pertença étnico-racial: $72,14 \%$ declaram-se brancos; $20,32 \%$ negros; $4,01 \%$ pardos e $3,54 \%$ pertencentes a outras etnias (índios, asiáticos, etc). Embora ainda pequena, a presença dos negros é proporcionalmente maior que em outras profissões.

d) Em relação aos vínculos empregatícios: 77,19\% dos profissionais possuem apenas um emprego (trabalham em apenas uma instituição); 11,74\% não possuem nenhum (desemprego ou trabalham em outras áreas); 10,31\% possuem duas ocupações na área e $0,76 \%$ três ou mais atuações como assistente social. Quanto à natureza da instituição em que exercem o vínculo principal, nota-se que $79,03 \%$ da categoria atuam no setor público (Federal, Estadual, Distrital, Municipal e de autarquias federais), enquanto 20,97\% alocam-se em empresas, terceiro setor, cooperativas, fundações e paraestatais. Em relação à renda média mensal: 45,19\% recebem nove ou mais salários mínimos; $18,59 \%$ entre sete e nove salários mínimos; $20,54 \%$ entre quatro e seis salários mínimos e $15,68 \%$ até três salários mínimos. A renda varia também conforme critérios das regiões do país. Quanto à titulação: 55,34\% dos profissionais possuem o nível de graduação; 36,26\% são especialistas; $6,49 \%$ são mestres; $1,24 \%$ doutores e $0,67 \%$ pós-doutores.

e) Quanto ao conhecimento acerca da legislação profissional, a tabela abaixo reflete posições bastante significativas, que indicam uma tendência de busca ou mesmo de (re)conhecimento de legislações mais relacionadas às atividades ordinárias institucionais:

\begin{tabular}{|c|c|c|c|c|c|}
\hline $\begin{array}{c}\text { Legislação x } \\
\text { conhecimento }\end{array}$ & $\begin{array}{c}\text { Diretrizes } \\
\text { curriculares }\end{array}$ & $\begin{array}{c}\text { Lei de } \\
\text { Regulamentação }\end{array}$ & $\begin{array}{c}\text { Código } \\
\text { de } \\
\text { Ética }\end{array}$ & $\begin{array}{c}\text { Tabela de } \\
\text { Honorários }\end{array}$ & $\begin{array}{c}\text { Legislação } \\
\text { respalda o } \\
\text { cotidiano? }\end{array}$ \\
\hline Sim & $43,89 \%$ & $90,55 \%$ & $96,37 \%$ & $32,73 \%$ & $60,31 \%$ \\
\hline Não & $56,11 \%$ & $9,45 \%$ & $3,63 \%$ & $67,27 \%$ & $39,69 \%$ \\
\hline
\end{tabular}

f) No que toca engajamento e participação política, $68 \%$ dos profissionais apontaram não participar de nenhuma atividade partidária, movimento sindical, movimento social ou mesmo movimentos da própria categoria profissional. Dentre os $32 \%$ que responderam afirmativamente, 44,8\% participam de movimentos e associações da categoria, enquanto $32,18 \%$ engajam-se em movimentos sociais (feministas, questões étnicas, minorias, etc); $23,02 \%$ são filiados ou exercem alguma atividade em sindicatos e partidos políticos. Interessante notar, porém, que dentre os que afirmaram participar, o nível de freqüência e/ou assiduidade é o seguinte: $54 \%$ de maneira assídua e $46 \%$ de modo eventual. 
Podemos citar - a guisa de clarificação - alguns elementos (entre tantos outros), exigências e/ou predicados que os autores do Serviço Social indicam ou destacam como componentes fundamentais na formação e exercício profissional na contemporaneidade. Maria Lúcia Lopes da Silva (2000) alinhava três dimensões: i) Consistentes e adequados conhecimentos teórico-metodológicos, que propiciem aos profissionais compreensões claras da realidade social e renovada identificação das demandas e possibilidades da ação profissional; ii) Realização efetiva dos compromissos ético-políticos estabelecidos pelo Código de Ética Profissional dos Assistentes Sociais, fundado nos valores democráticos e humanistas de liberdade, igualdade, justiça social, emancipação e cidadania dos sujeitos; iii) Constantes capacitações técnico-operacionais, que possibilitem a definição de estratégias e táticas na perspectiva de consolidação teórico-prática de um projeto profissional compromissado com os interesses e necessidades dos usuários, com a defesa dos direitos sociais, com a ampliação da esfera pública e com a construção de uma cidadania impulsionadora de novos direitos, fortalecendo a consciência de classe e a organização política, sindical e comunitária. A idéia de constante aprimoramento e especialização não quer significar, nesta perspectiva, um sinal de rendimento aos ditames e modismos do mercado neoliberal e às novas configurações assumidas pelo mundo do trabalho, embora a sobrevivência e sustento estejam aí inclusos (GRAVE, 2000). Conforme pondera lamamoto, o importante é que, para atingir os intentos do projeto ético-político da profissão, o(a) assistente social deve ser: "um profissional culto e atento às possibilidades descortinadas pelo mundo contemporâneo, capaz de formular, avaliar e recriar propostas no nível das políticas sociais e da organização das forças da sociedade civil. Um profissional informado, crítico e propositivo, que aposte no protagonismo dos sujeitos sociais. Mas, também, um profissional versado no instrumental técnico-operativo, capaz de realizar as ações profissionais, nos níveis de assessoria, planejamento, negociação, pesquisa e ação direta, estimuladoras da participação dos usuários na formulação, gestão e avaliação de programas e serviços de qualidade" (IAMAMOTO, 2000:126). O sociólogo Pedro Demo (1995), não necessariamente referindo-se somente aos assistentes sociais, condensa esta necessidade da conjugação crítica e autocrítica das competências e habilidades técnicas e políticas (tanto individuais quanto coletivas) nos seus conceitos de qualidade formal (formação técnica) e qualidade política (competência ética). Potyara Pereira (1996) ressalta que o (a) assistente social não pode nunca perder de vista a perspectiva da assistência social (e políticas sociais gerais) enquanto direitos. José Paulo Netto (1999) cita a premência do caráter interdisciplinar e articulado a outras profissões. 


\section{0 - Por que Serviço Social?}

Neste capítulo serão apresentados os resultados e análises mais significativas dos levantamentos e estudos realizados junto a estudantes do segundo semestre de 2006 da Universidade de Brasília (UnB). Conforme já mencionado, a metodologia empregada na análise dos resultados priorizou métodos qualitativos (hermenêutica e dialética), mas não excluiu levantamentos quantitativos que pudessem fornecer como produto um contorno ou perfil mais geral da turma supracitada em termos socioeconômicos ${ }^{75}$. Logicamente, o caráter restrito e modesto deste estudo não permite estabelecer conclusões ou mesmo teses, nem tampouco constitui amostra estatística significativa para fins de generalização. A sua validade está em apontar ou levantar possíveis tendências, incógnitas e estímulos para o desenvolvimento de ulteriores pesquisas, mais aprofundadas e bem mais amplas. A hipótese deste estudo foi: a maioria dos estudantes do $1^{\circ}$ semestre do curso de Serviço Social não tem ainda definidos claramente os motivos que os levaram a escolher esta faculdade, subsistindo visões históricas das distintas tendências observadas na profissão.

\section{1 - Motivações e concepções: indagando calouros do $2^{\circ} / 2006$}

Nas duas primeiras semanas do segundo semestre letivo do ano de $2006^{76}$, contando com a autorização e colaboração decisiva da professora Rosa Helena Stein, expliquei os objetivos deste estudo (objetivos, caráter científico e confidencial) e distribuí aos 34 alunos matriculados na disciplina Introdução ao Serviço Social o questionário socioeconômico (levantamento quantitativo) e estas três perguntas (de ordem qualitativa):

a) Por que escolhi o curso de Serviço Social? Quais motivos, influências ou fatos foram mais decisivos neste processo?

b) O que entendo por Serviço Social?

c) O que considero mais importante para tornar-se assistente social?

Dos 34 estudantes convidados a participarem e colaborarem com o estudo, apenas 18 (logo: $53 \%$ do total) devolveram preenchidas as indagações solicitadas. Ainda que os $47 \%$ que não responderam às questões possam aventar possível falta de tempo ou mesmo esquecimento ${ }^{77}$, também podemos considerar o silêncio, abstenções e mesmo o índice de indiferença tão significativa enquanto informações qualitativas em potencial. Tal qual as argumentações reveladas, certas omissões (no contexto deste estudo) parecem indicar dúvidas quanto à escolha do curso, suas diretrizes e mesmo à permanência neste.

\footnotetext{
${ }^{75}$ O questionário e o formulário elaborados para o levantamento das informações encontram-se em anexo (item 9.0).

${ }^{76}$ Entre os dias 28 de agosto e 09 de setembro.

${ }^{77}$ Comprometi-me a comparecer à turma mesmo depois de passados os prazos iniciais, minimizando manifestações nestes vieses.
} 


\section{2 - Perfil socioeconômico}

Conforme mencionado, 18 do total de 34 alunos (53\%) matriculados na disciplina Introdução ao Serviço Social respondeu ao questionário e à pesquisa qualitativa. Assim, os resultados apresentados a seguir revelam tão somente possíveis contornos gerais da realidade socioeconômica daquela turma, não compondo a amostra estatística esperada.

Dentre os dezoito alunos que responderam o estudo, verificou-se que $72 \%$ estão na faixa etária entre 17 e 20 anos (predominando 19 anos); 28\% contam 20 anos de idade ou mais (desvio padrão: 25 anos) ${ }^{78}$. Também predominam pessoas do sexo feminino: $83 \%$ são mulheres e apenas $17 \%$ são do sexo masculino, o que por sua vez pode sinalizar (hipoteticamente) que em médio prazo, em comparação com os atuais dados da pesquisa do CFESS, poderá haver uma ligeira tendência de aumento do ingresso de homens na profissão. Vejamos nas tabelas abaixo outros indicadores socioeconômicos relevantes:

\begin{tabular}{|c|c|}
\hline \multicolumn{2}{|c|}{ Tabela 1: Cidade onde reside } \\
\hline Brasília & $56 \%$ \\
\hline Taguatinga & $17 \%$ \\
\hline Samambaia & $11 \%$ \\
\hline Águas Claras, Planaltina e Sobradinho & $16 \%$ \\
\hline
\end{tabular}

Percebe-se, em termos de moradia e renda, que a maioria dos estudantes provém de famílias de classe média. Todavia, há um considerável índice (33\%) entre aqueles que se localizam, analisando a renda mensal, naquilo que se poderia chamar "classe-média-alta".

\begin{tabular}{|c|c|}
\hline \multicolumn{2}{|c|}{ Tabela 2: Renda mensal familiar } \\
\hline Não declarada & $6 \%$ \\
\hline Inferior a 2 salários-mínimos & $11 \%$ \\
\hline Entre 2 e 5 salários-mínimos & $22 \%$ \\
\hline Entre 5 e 10 salários-mínimos & $28 \%$ \\
\hline Acima de 10 salários-mínimos & $33 \%$ \\
\hline
\end{tabular}

Um dado bastante relevante é que a relativa maioria dos estudantes cursou grande parte ou totalmente o ensino fundamental e médio em escolas públicas (56\%), enquanto $44 \%$ estudaram em escolas particulares, percentual distinto da média percebida na UnB.

\footnotetext{
${ }^{78}$ Esta mesma tendência de predomínio de pessoas bem jovens (comparadas com algumas outras faculdades) no curso foi verificada na pesquisa Serviço Social: estudantes e os seus conceitos, realizada com os alunos do 1\%/2006 por Fábio Henrique Cerqueira Abreu, graduando em Serviço Social, no contexto da disciplina Pesquisa em Serviço Social 2.
} 
Em relação à participação anterior (que poderia motivar a escolha) em algum movimento social, ONG, partido político, sindicato, atividades de voluntariado, filantropia ou ainda algum trabalho de ação social na religião, verificou-se que $61 \%$ declararam a não-participação em nenhuma destas atividades, enquanto 39\% afirmaram contato com alguma(s) destas experiências. Dentre estes últimos (participantes), 57\% referiram-se a atividades ligadas à caridade e religião, enquanto $29 \%$ citaram práticas voluntárias em entidades e projetos do terceiro setor e $14 \%$ afirmaram exercer filantropia eventualmente.

\section{3 - Apresentação e análise crítica dos dados qualitativos}

Conforme já explicitado no capítulo 2 (item 2.2), vali-me no estudo qualitativo de dois métodos bastante empregados nas Ciências Humanas: a hermenêutica e a dialética. Três perguntas fundamentais foram elaboradas visando perceber, de forma mais ampla, as motivações da escolha e entendimentos acerca do Serviço Social. A estrutura de apresentação em cada pergunta é a seguinte: a) citação de argumentações e respostas mais emblemáticas; b) análise hermenêutica: recorrências de palavras e idéias; c) análise dialética: elaboração crítica a partir das percepções, recorrendo aos referenciais teóricos.

\section{a) Por que escolhi o curso de Serviço Social? Quais motivos, influências ou}

\section{fatos foram mais decisivos neste processo?}

1) "Desde os 12 anos eu queria trabalhar a favor da sociedade carente. Queria achar algo em que me dedicasse inteiramente a favor dos injustiçados"./ "Porque eu me interesso em ajudar as pessoas e garantir seus direitos". I "Porque me identifiquei com o fato de ser útil às pessoas que tem necessidades e poder de alguma forma ajudá-las". I "Porque é um curso que lida com pessoas, políticas públicas e me dá uma oportunidade de tentar ajudar um pouco a sociedade, além da proximidade muito grande com minha primeira opção (Medicina)". I "Porque sou contra a miséria advinda do sistema capitalista, escolhi este curso porque ele busca, basicamente, suprimir as desigualdades e diferenças gritantes entre os indivíduos da sociedade".

2) "Pelo prazer e satisfação que tive durante os três anos que trabalhei como voluntária com crianças carentes". I "Além do diploma e ter uma profissão, conhecimentos teóricos e técnicos que me ajudem nas atividades sociais em minha igreja". I "Tenho perfil condizente com a profissão".

3) "Por ser um curso que possui uma vasta área ocupacional" / "O que mais me chamou atenção no curso é a diversidade de áreas que o profissional pode trabalhar". I "Por ser um curso da área de Humanas, vi umas matérias que tem e gostei". I "Depois que vi o fluxo do curso".

4) "Devido a conversas com assistentes sociais na minha família". I "Pela conversa que tive com duas pessoas muito importantes (...). Percebi em suas palavras grande admiração pelos assistentes sociais". / "Influência de um amigo e de uma tia que queria muito que eu fizesse".

5) "A nota de corte do Serviço Social é mais baixa". I "A concorrência é bem menor". 
Análise hermenêutica: agrupadas algumas argumentações, nota-se a recorrência impressionante do termo 'ajuda' e suas variantes por várias vezes relacionadas à atuação ou como papel do Serviço Social, embora também se pondere que a palavra aparece mesclada logo em seguida como idéia de ajudar na garantia e conquista dos direitos. Este verbete apareceu durante 28 vezes nas redações elaboradas, em $56 \%$ dos textos dos estudantes. Uma outra idéia ou sentido forte em quase todas as argumentações é a de que a profissão é muito mais para favorecer aos outros do que a si mesmo (altruísmo), a ponto de ser percebida como uma doação total à causa dos pobres. Ademais, nota-se a questão da satisfação advinda por ser útil à sociedade, sobretudo aos mais pobres ou injustiçados. A questão de 'gostar de trabalhar com pessoas' também emerge em vários aspectos, bem como a vinculação desta característica a uma possível vocação inata. Ademais, percebe-se a revelação de que alguns foram influenciados na escolha por conta de experiências voluntárias ou religiosas anteriores, ou ainda com o intuito de buscar conhecimentos que contribuam para uma melhor participação nestes espaços. $\mathrm{E}$, em se tratando de influências, um outro aspecto bem interessante (e mesmo decisivo) para a escolha do Serviço Social por parte de alguns parecem ser as conversas ou contatos com profissionais ou, ainda, o testemunho de familiares e/ou amigos em favor da profissão, revelando um relativo prestígio da representação social que esta possui junto a outras categorias ou mesmo à sociedade em geral. A questão da diversidade de áreas e amplas possibilidades de atuação como assistente social também estimulam as pessoas, assim como a percepção de disciplinas que despertam o interesse pela profissão. Por fim, há que se comentar que o Serviço Social não era, para muitos (44\%), a opção inicial de curso superior. Neste contexto, a escolha pela faculdade varia então desde aquelas questões mais pragmáticas geradas pela concorrência (como nota de corte mais baixa) até eventuais aproximações com as áreas de maior afinidade (saúde, por exemplo).

Análise dialética: logicamente, não era a nossa expectativa que os estudantes tecessem verdadeiros tratados e/ou ensaios acerca do Serviço Social e temas correlatos, nem tampouco já apresentassem na primeira semana de aula a plena convicção e clareza acerca da escolha. Todavia, podemos perceber, para além de questões de conveniências bem pessoais, a reveladora presença de elementos, concepções, códigos de linguagem, posicionamentos e até mesmo dos equívocos notados na trajetória histórica da profissão. A constante associação da profissão à ajuda (seja aos pobres ou à sociedade em geral) revela, dentre outras coisas, a persistência de idéia perigosamente generalista de que os assistentes sociais são necessariamente pessoas bondosas, engajadas, solidárias, 
altruístas ou muito comprometidas com as causas dos trabalhadores ou dos 'injustiçados'. Embora o comprometimento efetivo e sincero com as demandas populares seja um anseio do atual projeto ético-político da profissão, cabe reconhecer que nem sempre esta é a postura profissional particular e/ou institucional que ocorre na prática, até porque o caráter dialético - ou de unidade de contrários -, ambíguo e contraditório das políticas sociais em território capitalista não gesta sínteses monolíticas e/ou homogêneas, podendo tanto ser instrumentos de emancipação a quem a elas recorre como, de outro lado, cultivo da condição de 'massa de manobra' e perpetuação das pobrezas de ordem material e política. Pareceu-me claramente herança de sentido neotomista todas as construções da profissão como desprendimento, uma doação total (quase um sacerdócio) ou de utilidade somente aos outros. Ademais, certos depoimentos aproximam-se de uma reedição no tempo e no espaço da busca da profissão como saber técnico-operacional que embasará qualitativamente atuações na esfera social das atividades das igrejas. Também a confusão entre o trabalho voluntário (gerando satisfação e prazer) realizado em espaços do terceiro setor ou de religiões (caridade e preceitos de fé) como suposta afinidade vocacional ao Serviço Social obscurece a real identidade profissional assumida no capitalismo. Por outro lado, emergiram também certas idealizações exageradas/messiânicas referentes ao perfil da profissão semelhantes àquelas empregadas pelas correntes marxistas nos primórdios do movimento de Reconceituação, como, por exemplo, a noção de que caberia ou seria objetivo da profissão: "suprimir as desigualdades e diferenças gritantes entre os indivíduos da sociedade". Logicamente, sabemos que as resoluções destas questões envolvem mudanças profundas (estruturantes e estruturais), que incluem redistribuição de renda, alteração de relações entre capital e trabalho e superação de paradigmas vigentes.

\section{b) O que entendo por Serviço Social?}

1) "Poder ajudar as pessoas, orientando-as de como buscar seus direitos e também resolver problemas que sozinhas elas não encontrariam uma direção correta". I "É uma profissão lindíssima que se preocupa com a humanidade e que acredita e trabalha para melhorar a sociedade". I "Conscientizar as pessoas e implantar projetos sociais, a fim de alcançar um mundo melhor". I "Oferecer o acesso aos meios para que a própria pessoa alcance o fim". I "Integrar os excluídos".

2 ) "Atuar como um mediador entre a classe dominante e a classe marginalizada, procurando meios de garantir os direitos dessa última classe, mas, de certa forma, estando a serviço da primeira". I "Aquela que se embasa na contradição das classes sociais e, mais especificamente, vem ao encontro das classes subalternas com função de mostrar e assegurar o direito das pessoas". I "Uma forma de reduzir desigualdades através de políticas sociais e não de caridade como muitos pensam". I "Favorecer a libertação das pessoas". I "Reduzir as alienações e enganos". 
3) "Uma profissão que garante o direito das pessoas". I "A possibilidade de tentar melhorar a sociedade, mostrando-a seus direitos e deveres". I "É garantir direito: direito à dignidade, ao respeito, à política, direito civil... direito à cidadania. É estudar as relações humanas em todas as suas formas". / "Minimizar os disparates sociais, por meio do esclarecimento e da divulgação dos direitos constitucionais de cada indivíduo". I "Ajudar as pessoas a buscarem exercer seus direitos".

Análise hermenêutica: palavras e expressões que apareceram com freqüência: direitos; melhorar a sociedade/mundo melhor; ajudar; pessoas; conscientizar; divulgar. Há uma recorrência de usos de verbos no infinitivo ao referir-se ao que seria o Serviço Social, revelando o entendimento do protagonismo da prática profissional junto à sociedade ou às pessoas que procuram os assistentes sociais. Tendência de construção da prática do assistente social enquanto educador popular. Aproximação a concepções funcionalistas, que entendem que seria papel do Serviço Social contribuir na 'integração' das pessoas (os excluídos) a uma suposta ordem e normalidade da sociedade. Também se percebe contatos com categorias e terminologias da tradição marxista, tais como: mediador; classe dominante; classes subalternas; contradição das classes sociais; alienações.

Análise dialética: notam-se nas diversas construções e falas a recorrência da associação da profissão à garantia, esclarecimento e divulgação dos direitos e deveres. Todavia, por muitas vezes retoma-se a idéia do profissional como aquele que 'ajuda', 'favorece' ou 'conscientiza' as pessoas, aproximando-o em muitos casos de um papel tão ativo (protagonista) que concebe as pessoas que o procuram como meros espectadores passivos, que só teriam estimulado a consciência dos direitos após um eventual contato com os assistentes sociais, pois: "sozinhas elas não encontrariam uma direção correta". Por outro lado, uma idéia de cariz liberal muito difundida - qual seja: ao invés de dar o peixe, ensinar a pescar - apareceu reescrita de modo mais sofisticado, como: 'oferecer os meios para que a própria pessoa alcance o fim'. Ainda que uma análise contextual possa indicar que a intenção tenha sido afirmar (em sentido nobre) que a profissão deve buscar favorecer a autonomia da pessoa, ainda assim subsiste o tônus individualista liberal da concepção, porquanto se alimenta a idéia de que a ação do Serviço Social limita-se ao papel neutro e relativo de somente distribuir meios, abrindo mão do aspecto ético-político, que propõe o engajamento efetivo dos profissionais visando fins maiores de superação dos problemas e entraves vigentes para construção de uma nova ordem social. Alguns termos e expressões reiteram também expectativas bem pouco dialéticas, unilaterais ou fatalistas da profissão, como, por exemplo, a idéia de que sempre está preocupada com a melhoria da humanidade e/ou sociedade, ou de que está 'a serviço da classe dominante'. 


\section{c) O que considero mais importante para tornar-se assistente social?}

1) "Gostar de lidar com pessoas e não se conformar com a atual realidade da sociedade".l "Gostar de pessoas e acreditar em mudanças". I "Uma sensibilidade às questões sociais; interesse em querer modificar a sociedade vigente; disponibilidade para trabalhar com os mais diversos tipos de pessoas e situações sociais". / "Ter uma visão mais humanista do mundo; parar de pensar muito em si mesmo e começar a pensar e, acima de tudo, ajudar o próximo". / "Apresentar um perfil humano, de preocupação social e engajamento (...). Possuir ferramentas teóricas e práticas para ir ao auxílio da sociedade". / "Muita paciência. Saber ouvir. Alto índice de responsabilidade, respeito com as pessoas e, acima de tudo, fazer as coisas com amor". I "A máxima atenção a quem quer que esteja assistindo, já que seu 'objeto' de trabalho são pessoas e não fantoches".

2) "Conhecer os problemas sociais de perto". I "Estar bem informado e consciente dos problemas sociais". I "Desejo de contribuir para a diminuição das desigualdades sociais e um senso crítico em relação a esse capitalismo selvagem. Mas o mais importante para mim é o amor pela causa social". / "É ter o senso de justiça, vontade de ajudar e a força para lutar".

3) "Ter a real consciência de que, mesmo que trabalhemos a vida toda não conseguiremos acabar nunca com a desigualdade; com isso não nos tornaremos profissionais tão frustrados".

Análise hermenêutica: repetiu-se por diversas vezes a idéia de que a vocação de um assistente social revela-se pelo gostar /saber lidar com as pessoas. Destaca-se aí o sentido ético de profundo respeito pelas pessoas que procuram tal profissional (usuários). Outra aproximação interessante a este tema é o entendimento do perfil humano ou humanista que a profissão e/ou o assistente social deve possuir, renunciando a busca da dimensão do que se refere tão somente a si mesmo (egoísmo; interesses particulares) em nome da ajuda ou auxílio às pessoas ou à sociedade em geral. O amor também é citado como motivação e pressuposto para o bom exercício profissional, referindo-se não só às pessoas, mas também à causa social. Revela-se importante o fato de conhecer bem, estar bem informado, consciente e ter senso crítico em relação às mazelas capitalistas.

Análise dialética: é admirável notar o nível de solidariedade às pessoas e sede por colaborar para mudanças na ordem social vigente (senso de justiça) que os estudantes demonstraram. Ainda que seja fator importante, em nenhuma citação a escolha do curso foi vinculada à busca pelo status quo ou apenas ao progresso financeiro. Embora em alguns casos o desprendimento se aproxime de humanismo neotomista ou de idealismos, mesmo assim é interessante percebê-lo tão forte em jovens que cresceram em meio a contextos sociais consumistas e individualistas estimulados pelo capitalismo. Por outro lado, parece lamentável (ainda mais em alguém que inicia) a visão fatalista de pensar que nossa ação não muda quase nada em termos de redução das desigualdades sociais... 


\section{0 - Considerações finais}

Os dados obtidos neste estudo não podem ser tomados enquanto pretensas indicações precisas e amplas acerca dos motivos e concepções que levam à escolha da profissão ${ }^{79}$. Todavia pareceu-nos que resultaram em instigantes (daí possível validade) propostas para a realização de ulteriores incursões mais aprofundadas, que contemplem também maior universo de estudantes e/ou profissionais pesquisados. Duas sinalizações e/ou constatações mais visíveis e concretas emergiram após a análise das informações:

1) A hipótese inicial de que a escolha e/ou a visão acerca do curso estaria de algum modo vinculada a representações sociais advindas de heranças remanescentes das concepções teóricas e ideológicas ${ }^{80}$ ligadas à história da profissão tende a ser confirmada. Ressalta-se, porém, que não são transposições lineares, idênticas ou monolíticas. Na verdade, há forte recorrência (por vezes num mesmo discurso) da mescla dos elementos das diferentes correntes teóricas e concepções ideológicas, por vezes contrárias entre si.

2) O projeto ético-político do Serviço Social carece de melhor divulgação em todos os aspectos e meios, pois não atingiu ainda clara visibilidade ou nítida compreensão por boa parte da sociedade. Não raro, prevalecem ainda - a respeito da visão sobre o Serviço Social - os prejudiciais utopismos, fatalismos, messianismos e equívocos exagerados.

Enfim, vale dizer que a construção do Serviço Social é um processo não-linear e dialético, logo, aberto, dinâmico e permanente, que incorpora as contradições decorrentes da inserção desta atividade e dos seus profissionais na própria sociedade. Há de se valorizar a diversidade/pluralidade de concepções típicas na história da profissão, desde que não percamos de vista os preceitos e postulados colocados pelo projeto ético-político. Embora: "o sujeito coletivo que constrói o projeto profissional é um universo heterogêneo: os membros da categoria profissional são, necessariamente, indivíduos diferentes - têm origens e expectativas sociais diversas, condições intelectuais distintas, comportamentos e preferências teóricas, ideológicas e políticas variadas, etc. A categoria profissional é uma unidade não-identitária, uma unidade de elementos diversos; nela estão presentes projetos individuais e societários diversos e, portanto, ela é um espaço plural do qual podem surgir projetos profissionais diferentes" (NETTO, 1999:96). Cabe-nos buscar, deste modo, a unidade na diversidade, pois: "considerado o pluralismo profissional, o projeto hegemônico de uma determinada categoria comporta um pacto entre seus membros" (idem: 98).

\footnotetext{
${ }^{79}$ Conforme dito, tratou-se aqui de pesquisa realizada junto a uma turma de calouros, onde nem todos responderam.

${ }^{80}$ Refiro-me aqui às marcas que permanecem ou se renovam das influências mais ou menos intensas das concepções cristãs neotomistas, do positivismo e do funcionalismo, do desenvolvimentismo, do marxismo e da fenomenologia. Como exemplos alinhavo: associação do perfil profissional do assistente social relacionando-o à ajuda assistencialista, militância política, solidariedade, caridade, desprendimento pessoal, filantropia ou voluntariado em organizações do terceiro setor.
} 


\section{Referências bibliográficas}

ALAYÓN, N. Assistência e assistencialismo: controle dos pobres ou erradicação da pobreza? 2.ed. São Paulo: Cortez, 1995 (tradução de Balkys Villalobos de Netto).

ANTUNES, R. Adeus ao trabalho? Ensaio sobre as metamorfoses e a centralidade do mundo do trabalho. São Paulo: Cortez/Unicamp, 1995.

. Os sentidos do trabalho - ensaio sobre as metamorfoses e centralidade do mundo do trabalho. São Paulo: Boitempo Editorial, 1999.

APEL, K. Transformação da filosofia I: filosofia analítica, semiótica, hermenêutica. São Paulo: Edições Loyola, 2000.

BENTO 16, papa. Deus caritas est. Cidade do Vaticano: 2006 (encíclica papal).

BERGER, K. Hermenêutica do novo testamento. São Leopoldo, RS: Sinodal, 1999.

BEHRING, E. R. A ação dos trabalhadores da consolidação da assistência social como direito.

In: SER SOCIAL no 12, p. 37-58. Brasília: Departamento de Serviço Social, 2003. BOSCHETTI, I. Assistência social no Brasil: um direito entre originalidade e conservadorismo. 2.ed. Brasília: GESST/SER/UnB, 2003.

CARVALHO, A. S. Metodologia da entrevista: uma abordagem fenomenológica. Rio de Janeiro: Editora Agir, 1991.

CARVALHO, R. \& IAMAMOTO, M.V. Relações sociais e Serviço Social no Brasil. 11. ed. São Paulo: Cortez, 1996.

CASTEL, R. As metamorfoses da questão social - uma crônica do salário. Petrópolis, RJ: Vozes, 1998.

CASTRO, M. M. História do Serviço Social na América Latina. 5.ed. São Paulo: Cortez, 2000.

CONSELHO FEDERAL DE SERVIÇO SOCIAL. Assistentes Sociais no Brasil - Elementos para o estudo do perfil profissional. Brasília: CFESS, 2005.

DEMO, P. Avaliação qualitativa. 5.ed. Campinas, SP: Autores Associados, 1995.

.Dialética da ajuda. In: SER Social n 6, p.185-206. Brasília: Departamento de Serviço Social, 2000 (janeiro a junho).

. Pesquisa e informação qualitativa. Campinas, SP: Autores Associados, 2001. . Solidariedade como efeito de poder. São Paulo: Cortez, 2002.

. Complexidade e aprendizagem - a dinâmica não-linear do conhecimento. São

Paulo: Atlas, 2002.

ESTEVÃO, A. M. R. O que é serviço social? 6.ed. São Paulo: Brasiliense, 1999.

FALCÃO, M. C. B. C. Serviço Social: uma nova visão teórica. 4.ed. São Paulo: Moraes, 1981.

FALEIROS, V. P. A política social do estado capitalista. 8. ed. São Paulo: Cortez, 2000. 
Natureza e desenvolvimento das políticas sociais no Brasil. In:

ABEPSS/CFESS/CEAD-UnB: Capacitação em Serviço Social e Política Social, p. 41-56, módulo 2, Brasília: 2000.

FERREIRA, O.C. Discurso de paraninfo. In: Revista de Serviço Social $\mathbf{n}^{\circ} \mathbf{2 5}$, ano 3, p.26-29, São Paulo: 1941.

FLEURY, S. Contra-reforma e resistência. In: INESC - A era FHC e o governo Lula: transição? p.123-148. Brasília: INESC, 2004.

FGV. Dicionário de ciências sociais. Rio de Janeiro: Fundação Getúlio Vargas, 1987.

FRANKL, V.E. Um Sentido para a vida. Aparecida do Norte, SP: Ed. Santuário, 1989.

GADAMER, H. G. Verdade e método: traços fundamentais de uma hermenêutica filosófica. Petrópolis, RJ: Vozes, 1997.

GOHN, M. da G. Políticas públicas e sociedade civil no Brasil nas últimas décadas. In: Novos Paradigmas da Política Social, p.311-330. Brasília: Departamento de Serviço Social, 2002.

GRAVE, F. Trabalho, desemprego e serviço social. In: Revista Serviço Social e Sociedade nº 69, p.73-106. São Paulo: Editora Cortez, 2000.

GUEDES, O. de S. A compreensão da pessoa humana na gênese do serviço social no Brasil: uma influência neotomista. Campinas, SP: Unicamp, 2000.

GUERRA, Y. Mediação e instrumentalidade no trabalho do assistente social. In: ABEPSS/CFESS/CEAD-UnB: Capacitação em Serviço Social e Política Social, módulo 4, p. 53-63, Brasília: 1999.

HABERMAS, J. Consciência moral e agir comunicativo. Rio de Janeiro: Tempo Brasileiro, 1989.

HAGUETTE, T.M.F. Metodologias qualitativas na sociologia. Petrópolis, RJ: Vozes, 1987.

HOZ, V. G. Pedagogia visível, educação invisível. São Paulo: Nerman: 1988.

IAMAMOTO, M. V. Renovação e conservadorismo no Serviço Social - ensaios críticos. 3.ed. São Paulo: Cortez, 1995.

. O serviço social na contemporaneidade: trabalho e formação profissional.

São Paulo: Cortez, 1998.

O Serviço Social em tempos de globalização. In: Revista Inscrita, ano 3, p. 13-17, Brasília: CFESS, 1998.

- O trabalho do assistente social frente às mudanças do padrão de acumulação e de regulação social. In: ABEPSS/CFESS/CEAD-UnB: Capacitação em Serviço Social e Política Social, módulo 1, p. 113-127, Brasília: 1999.

- Transformações societárias, alterações no mundo do trabalho e Serviço

Social. In: SER Social n 6, p.45-78. Brasília: Departamento de Serviço Social, 2000.

KISNERMAN, N. Sete estudos sobre Serviço Social. São Paulo: Cortez \& Moraes Itda, 1980. 
KOIKE, M. As novas exigências teóricas, metodológicas e operacionais da formação profissional na contemporaneidade. In: ABEPSS/CFESS/CEAD-UnB: Capacitação em Serviço Social e Política Social, módulo 2, p.103-118, Brasília: 1999.

KONDER, L. O que é dialética? 17ed. São Paulo: Brasiliense, 1987.

LAUAND, L. J. Tomás de Aquino hoje. Curitiba: PUC-PR, 1993.

LIBANIO, J. B. \& MURAD, A. Introdução à Teologia: perfil, enfoques, tarefas. 4.ed. São Paulo: Edições Loyola, 2003.

MANCINI, L.C. Formação profissional. In: Revista de Serviço Social, ano 1, n.2, 1939, p. 2-4.

MARCONDES, D. Iniciação à história da Filosofia: dos pré-socráticos a Wittgenstein. 10.ed. Rio de Janeiro: Jorge Zahar Editor, 2006.

MARÍAS, J. Ortega: las trayectorias. Madrid (Espanha): Alianza Editorial, 1983.

MARTINELLI, M.L. Serviço social: identidade e alienação. 10.ed. São Paulo: Cortez, 2006.

MARX, K. O capital - livro I, vol. I: o processo de produção do capital. 14 ed. Rio de Janeiro: Bertrand Brasil, 1994 (tradução de Reginaldo Sant'Anna).

MONDIN, B. O homem, quem é ele? Elementos de antropologia filosófica. 11. ed. São Paulo: Paulus, 2003 (Coleção filosofia).

MONTAÑO, C. Terceiro setor e questão social: crítica ao padrão emergente de intervenção social. São Paulo: Cortez, 2002.

NETTO, J. P. Capitalismo monopolista e Serviço Social. São Paulo: Cortez, 1992.

.A construção do projeto ético-político do Serviço Social frente à crise contemporânea. In: ABEPSS/CFESS/CEAD-UnB: Capacitação em Serviço Social e Política Social, módulo 1, p. 93-109, Brasília: 1999.

PADILHA, M. D. O compromisso profissional expresso na relação assistente social/cliente. Recife: Editora da UFPE, 1988.

PALMA, D. A prática política dos profissionais: o caso do Serviço Social. 2.ed. São Paulo: Cortez: Lima (Peru): CELATS, 1993.

PEREIRA, P. A. P. A assistência social na perspectiva dos direitos: crítica aos padrões dominantes de proteção aos pobres no Brasil. Brasília: Thesaurus, 1996.

POLANYI, K. A grande transformação: as origens da nossa época. 2.ed. Rio de Janeiro: Campus, 2000.

PONTIFICIA COMISSÃO PARA A SAGRADA ESCRITURA. A Interpretação da bíblia na Igreja. Cidade do Vaticano: 2002 (volume único).

RAMOS, M. H. R. Trabalho produtivo e trabalho improdutivo: uma contribuição para pensar a natureza do serviço social enquanto prática profissional. In: Revista da Associação Brasileira de Ensino e Pesquisa em Serviço Social - ABEPSS, ano 1, nº 2, p.59-89, 2000. 
RICOUER, P. Hermeneutics and the human sciences: essays on language, action and interpretation. Cambridge: Cambridge University Press, 1981.

SANTOS, W. G. Cidadania e justiça: a política social na ordem brasileira. 2.ed. Rio de Janeiro: Campus, 1987.

SANTOS, Y. Mulher e assistência: as afinidades eletivas. Disponível em formato PDF em: www.cpihts.com/PDF/Yara\%20Santos.pdf. Acesso em: 05/08/2006.

SELLTIZ, J. D et alii. Métodos de pesquisa nas relações sociais. São Paulo: Edusp, 1971.

SILVA, M. L. L. Um novo fazer profissional. In: ABEPSS/CFESS/CEAD-UnB: Capacitação em Serviço Social e Política Social, p. 114-124, módulo 4. Brasília: 2000.

SILVA, M. G.O. Ideologias e Serviço Social. 2.ed. São Paulo: Cortez, 1983.

SILVA E SILVA, M. O. Formação profissional do assistente social - inserção na realidade social e na dinâmica da profissão. São Paulo: Cortez, 1984.

SUPLICY, E. M. Renda de cidadania: a saída é pela porta. 2.ed. São Paulo: Cortez, 2002.

VIEIRA, B. O. Serviço social: visão internacional: 1928-1978. Rio de Janeiro: Editora Agir, 1982. 
- Universidade de Brasília - UnB

- Instituto de Ciências Humanas - IH

- Departamento de Serviço Social - SER

- Disciplina: Trabalho de Conclusão de Curso

\section{PERFIL SOCIOECONÔMICO}

1.0 - Idade: anos.

2.0 - Sexo:

() Masculino.

( ) Feminino.

3.0 - Cidade onde reside:

4.0 - A renda mensal média familiar é:

( ) Inferior a dois salários-mínimos;

( ) Entre dois e cinco salários-mínimos;

( ) Entre cinco e dez salários-mínimos;

( ) Acima de dez salários-mínimos;

5.0 - Cursou a maior parte do ensino fundamental e do ensino médio em:

( ) Escola pública.

( ) Escola particular.

6.0 - Participa ou já participou de algum movimento social, ONG, partido político, sindicato, atividades de voluntariado ou filantropia ou em pastorais, por exemplo?

() Sim.

( ) Não.

Qual (ou quais) destes? 
- Universidade de Brasília - UnB

- Instituto de Ciências Humanas - IH

- Departamento de Serviço Social - SER

- Disciplina: Trabalho de Conclusão de Curso

\section{Caro (a) colega,}

Esta pesquisa científica compõe o Trabalho de Conclusão de Curso do aluno Marcos Fernandes Aquino (matrícula: 01/26420), aluno do Departamento de Serviço Social da Universidade de Brasília. Solicitamos que você nos responda, em forma de texto em prosa, às seguintes questões:

a) Por que escolhi o curso de Serviço Social? Quais motivos, influências ou fatos foram mais decisivos neste processo?

b) O que entendo por Serviço Social?

c) O que considero mais importante para tornar-se assistente social?

*Continua em outras páginas... 